
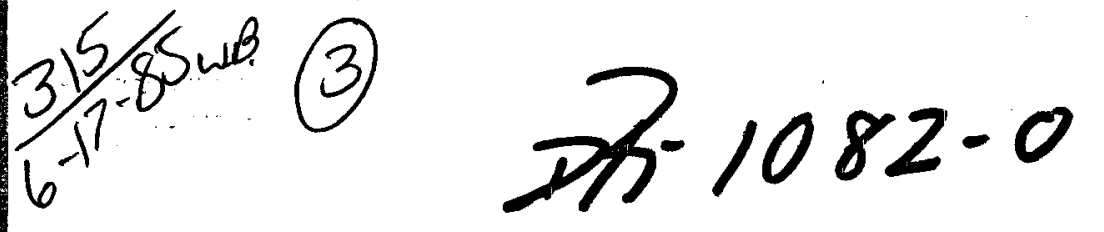

\title{
inergy
}

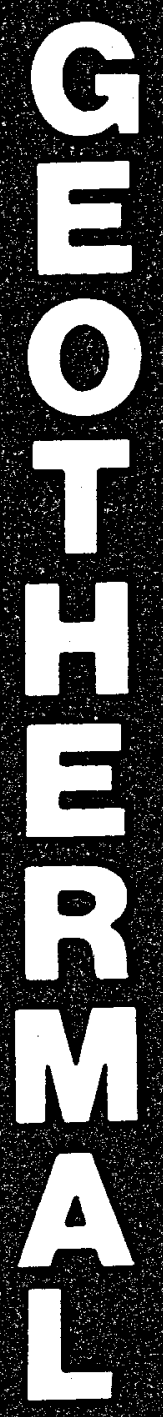

\section{OPTIMIZATION OF DESIGN AND CONTROL STRATEGIES FOR GEOTHERMAL SPACE HEATING SYSTEMS}

Final Report

By

James A. Batdorf

George M. Simmons

July 1984

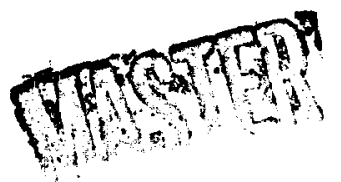

Work Performed Under Contract No. AS07-80ID12167

University of Idaho

Moscow, Idaho

Technical Information Center

Office of Scientific and Technical Information United States Department of Energy 


\section{DISCLAIMER}

This report was prepared as an account of work sponsored by an agency of the United States Government. Neither the United States Government nor any agency Thereof, nor any of their employees, makes any warranty, express or implied, or assumes any legal liability or responsibility for the accuracy, completeness, or usefulness of any information, apparatus, product, or process disclosed, or represents that its use would not infringe privately owned rights. Reference herein to any specific commercial product, process, or service by trade name, trademark, manufacturer, or otherwise does not necessarily constitute or imply its endorsement, recommendation, or favoring by the United States Government or any agency thereof. The views and opinions of authors expressed herein do not necessarily state or reflect those of the United States Government or any agency thereof. 


\section{DISCLAIMER}

Portions of this document may be illegible in electronic image products. Images are produced from the best available original document. 


\title{
DISCLAIMER
}

This report was prepared as an account of work sponsored by an agency of the United States Government. Neither the United States Government nor any agency thereof, nor any of their employees, makes any warranty, express or implied, or assumes any legal liability or responsibility for the accuracy, completeness, or usefulness of any information, apparatus, product, or process disclosed, or represents that its use would not infringe privately owned rights. Reference herein to any specific commercial product, process, or service by trade name, trademark, manufacturer, or otherwise does not necessarily constitute or imply its endorsement, recommendation, or favoring by the United States Government or any agency thereof. The views and opinions of authors expressed herein do not necessarily state or reflect those of the United States Government or any agency thereof.

This report has been reproduced directly from the best available copy.

Available from the National Technical Information Service, U. S. Department of Commerce, Springfield, Virginia 22161.

\author{
Price: Printed Copy A05 \\ Microfiche A01
}

Codes are used for pricing all publications. The code is determined by the number of pages in the publication. Information pertaining to the pricing codes can be found in the current issues of the following publications, which are generally available in most libraries: Energy Research Abstracts (ERA); Government Reports Announcements and Index (GRA and I); Scientific and Technical Abstract Reports (STAR); and publication NTIS-PR-360 available from NTIS at the above address. 
OPTIMIZATION OF DESIGN AND CONTROL STRATEGIES

FOR GEOTHERMAL SPACE HEATING SYSTEMS

\author{
by \\ James A. Batdorf \\ George M. S1mmons \\ Department of Chemical Engineering \\ Untversity of Idaho \\ Moscow, Idaho 83843
}

July 1984

Final Report

Contract \# DE-AS07-80ID12167 MOD A001

\author{
Submitted to \\ Elizabeth Hyster, Contract Administrator \\ Department of Energy \\ Idaho Operations office
}


The efficient design and operation of geothermal space heating systems requires careful analysis and departure from normal design practices. Since geothermal source temperatures are much lower than elther fossil fuel or electrical source temperatures, the temperature of the delivered energy becomes more critical. Also, since the geothermal water is rejected after heat exchange, it is necessary to extract all of the energy that is practical in one pass; there is no second chance for energy recovery.

The present work examines several heating system configurations and describes the desired design and control characteristics for operation on geothermal sources. Spectfic design methods are outlined as well as several generalized guidelines that should significantly improve the operation of any geothermally heated system. 
TABLE OF CONTENTS

page

1.0 Geothermal Space Heating . . . . . . . . . . . . . . 1

1.1 Project objectives .................... . . 3

1.2 Modeling of Geothermal Heatlng Systems . . . . . . . . . . 4

2.0 Individual System Analysis . . . . . . . . . . . . . 8

2.1 System 1: Varlable Alr Volume .................. 11

Heating System Description . . . . . . . . . . . 11

General Control Methods ................... 13

Central Untt Controls ................... 13

System 1 Analysts ...................... 17

Loop Water Flow Optimization ................ 17

Afr-Water Heat Exchanger Size ............... 19

Plate Heat Exchanger Slze ................. 19

2.2 System 2: Dual Duct (Constant Volume) . . . . . . . . . 22

System Description ...................... 22

System Control . . . . . . . . . . . . . . . . . 22

Geothermal Operation .................. 24

2.3 System 3: Varlable A1r Volume with Terminal Reheat . . . . . 25

System Description ........ . . . . . . . 25

System Control ........................ 25

Geothermal operation .................... 27

2.4 System 4: Single Zone Flxed Volume . . . . . . . . . . 29

System Description . . . . . . . . . . . . 29

System Control . . . . . . . . . . . . . 29

Geothermal operation............... 29

2.5 System 5: Induction Un1t .................... 33

System Operation . . . . . . . . . . . . . 33

Geothermal Operation .................. 33

3.0 Economic Declsions in Geothermal Systems . . . . . . . . . 35

3.1 Equipment Selection . . . . . . . . . . . . . 36 
3.2 System Econorle Analysts . . . . . . . . . . . . . 45

"Economical Advantages in Using Conventional

Energy Supplements in the Design of District

Geothermal Heating Systems," presented at the

Geothermal Resources Council meeting, Portland, Ore.,

October, 1983.................... 46

4.0 Summary of Recommendations . . . . . . . . . . . . 51

4.1 Loop Water flow . . . . . . . . . . . . . . . . 51

4.2 Des1gn Temperature . . . . . . . . . . . . . . . . 52

4.3 Maximizing Heat Exchanger Efficiency . . . . . . . . . . . 53

4.4 Heat Exchanger Design . . . . . . . . . . . . . . . 54

4.5 Three-Way Mixing Valves . . . . . . . . . . . . . 55

4.6 Controlling Geothermal Flow . . . . . . . . . . . . 55

4.7 Additional Control Strategles . . . . . . . . . . . . 56

4.8 Personnel Qualifications . . . . . . . . . . . . . 57

4.9 Energy Accountabil1ty . . . . . . . . . . . . . . 57

5.0 GEMS Program Methods . . . . . . . . . . . . . . . 58

5.1 Fresh Alr Control . . . . . . . . . . . . . . . 58

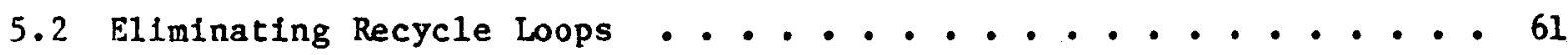

5.3 Determining Controller Gains . . . . . . . . . . . . . 61

5.4 Combining Heat Exchangers . . . . . . . . . . . . . 64

Append1x A . . . . . . . . . . . . . . . . . . 65

Appendix B . . . . . . . . . . . . . . . . . . . . 81

References ............................. 88 


\section{LIST OF TABLES}

page

Table 1: Prlmary Features of Hypothetlcal Office

Structure and Heating System ...............

Table 2: Example of Detalled Geothermal Water Use

Calculation ................... 4 40

Table 3: Summary of Detalled Geothermal Water Use

Calculations . . . . . . . . . . . . . 40 40

Table 4: Geothermal Flow Required Using Various

Air-Water Heat Exchangers ................ 42

Table 5: Incremental Cost Savings for Increased

Heat Exchanger Capac1ty ............. . 43

Table 6: Geothermal Water Required for Colder Climate

for Varlous Air-Water Heat Exchangers . . . . . . 43

Table 7: Incremental Cost Savings for Increased Heat

Exchanger Capac1ty - Colder Cllmate . . . . . . . . 44 
LIST OF FIGURES

page

Figure 1. Conventional Space Heating System . . . . . . . . . 2

Figure 2. Geothermal Water Space Heating System . . . . . . . 2

Figure 3a. Direct Transfer to Alr . . . . . . . . . . . 7

Figure 3b. Indirect Heat Transfer to Alr . . . . . . . . 7

Figure 4a. Control of Dellvered Energy by

Throttling the Geothermal Water Flow .......... 10

Figure 4b. Control of Dellvered Energy Using

a Three-way Mixing Valve... . . . . . . . . 10

Figure 5. Varlable Alr Volume System with

Hot and Cold Ducts . . . . . . . . . . . . 12

Figure 6. Control Operation of Terminal Reheat

Colls in Varlable Atr Volume System . . . . . . . . 14

Figure 7. Energy Control Methods for Terminal

Reheat Colls .................. 16

Figure 8. Changes in Required Geothermal Flow as a

Function of Loop Water Flow at Varlous

Heat Ing Loads . . . . . . . . . . . . . 18

Figure 9. Geothermal Flow Variations as a Function

of Afr-Water Heat Exchanger Design . . . . . . . 20

Figure 10. Geothermal Flow Varlations as a Function

of Plate Heat Exchanger Design ... . . . . . . . 21

Figure 11. Dual Duct Constant Volume Heating System . . . . . . 23

Figure 12. Varlable Alr Volume System with Terminal Reheat . . . 26

F1gure 13. Block Dlagram for VAV-Terminal Reheat System

with Three Zones . . . . . . . . . . . . . 28

Figure 14. Constant Volume System with Face and Bypass

Damper Control .................... 30

Figure 15. Constant Volume Variable Temperature System . . . ... 31

Figure 16. Control Strategy of Constant Volume System . . . . . 32 
$-v i i-$

Figure 17. Induction Plenum and Heater ........... 34

Figure 18. Heating Loss for Hypothetical office

Building at Various Ambient Temperatures

38

Figure 19a. Conventional Single Zone Fixed Air Volume Heating System

59

Figure 19b. GEMS Block Diagram for Heating System

(AWHXX = Air Water heat Exchanger) .......... 59

Figure 20. GEMS Block Diagram for Fresh Afr Control . . . . . 60

Figure 21. Simplified GEMS Block Diagram for Dual Duct

Constant Volume Heating System ............ 62

Figure 22. GEMS Block Diagram for Single Duct VAV with Terminal Reheat............... 63

Figure A-1. Comparison of GEMS Model with Bohr Data . . . . . 72

Figure A-2. Comparison of GEMS Model with Titus Data ....... 73 


\subsection{GEOTHERMAL SPACE HEATING}

The Northwestern United States has many known geothermal resource areas wtth a large amount of this potential energy reserve being located in the State of Idaho (1). The geothermal energy reserves in Idaho are primar1ly in the form of low temperature $(<200 \mathrm{~F})$ hot water $(2,3)$. This water is of ten of high quality, ranging from better than potable water standards to constituent concentrations approximating those of nearby surface waters (4).

These geothermal reserves are best utllized for space heating, as other areas of potential use, such as agricultural processing, industrial processing, or electrical production require higher temperature reserves for practical application.

The current practice for equipment design and operation of a geothermal space heating system is based on recognized methods that have been developed for conventional energy source systems. This method of design yields a working system at minimal design costs, however, it does not generally provide the most efficient uttilization of the geothermal resource.

Geothermal heating systems differ from other heating systems in the determination of efficlency. Most energy sources used for space heating (coal, electricity, natural gas, fuel ofl, wood) convert and transfer energy to a heating medium in a boller or simflar unit (Figure 1). The amount of energy converted and transferred depends primarily on the equipment design. Since the energy is supplied at temperatures much greater than the heating medium the efficiency is insensitive to the temperature of heating medium and depends primarily on the efficlency of the conversion to thermal energy. In a geothermal heating system, energy is transferred from the geothermal water to the heating medium in a counter-current heat exchanger (Figure 2). The amount of energy removed from the geothermal water is dependent on the temperature change of the geothermal water; therefore, a lower geothermal water discharge 


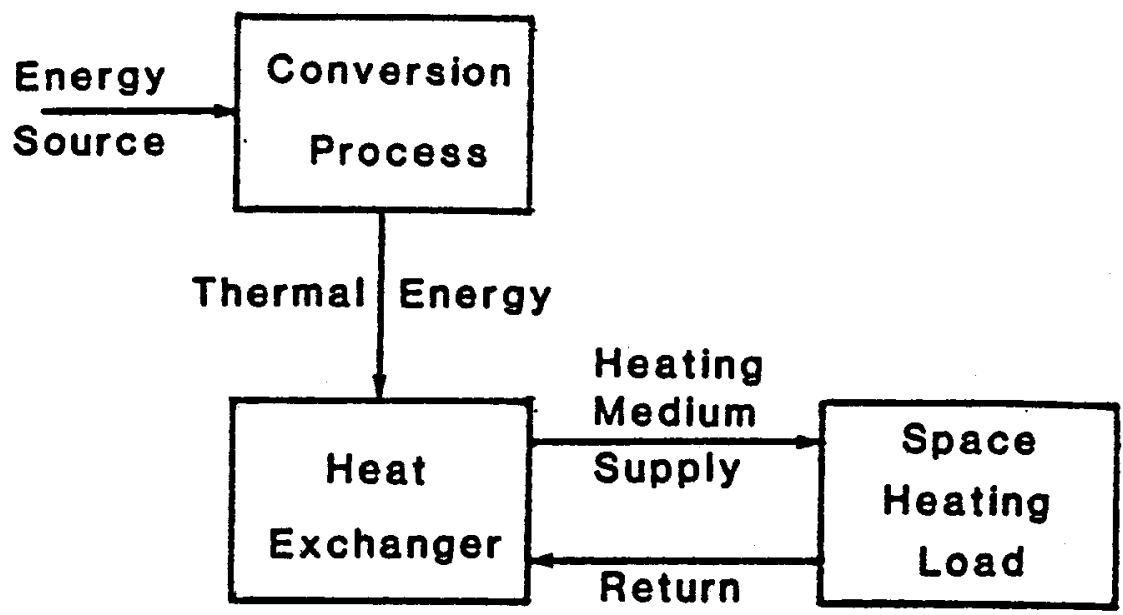

FIGURE 1. Conventional Space Heating System

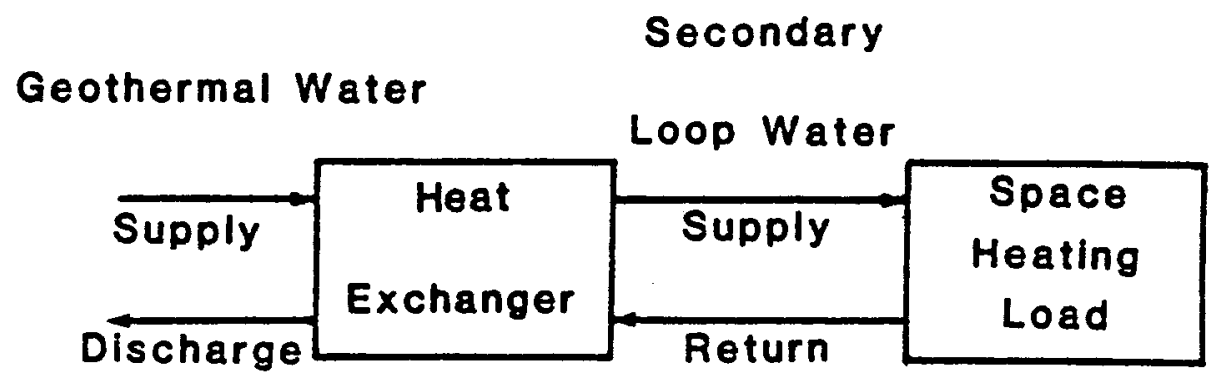

FIGURE 2. Geothermal Water Space Heating System 
temperature results in more energy extracted per unit mass of geothermal water and a higher "efficlency". The geothermal discharge temperature from a counter-current heat exchanger is determined directly by the return temperature of the heating medium and the size of the heat exchanger. An. appropriate definition of efficlency uses amblent temperature as the base or lowest posslble temperature to which the geothermal can be cooled. Efficlency Is then the actual temperature drop of the geothermal water divided by the maximum possible temperature drop. Therefore, in order to maximlze the utilization of geothermal water it is necessary to mimimize the return temperature of the heating medium. This requires a detalled knowledge of the heating system response to changes in equipment, operation, and control strategies.

\subsection{PROJECT OBJECTIVES}

The goal of this project was to establish a set of guldelines that would aid architects and engineers in the design and operation of geothermal heating systems. In order to achieve this goal it has been necessary to do an in depth analysis of geothermal heating systems and to determine those factors that are most relevant to efficlent operation. Th1s has been accomplished by detailed analysis of various system configurations with the assistance of different computer programs. One program, TRNSYS (Transient Simulation and Analysis Program, developed at the University of Wisconsin) (5) was used to provide an estimate of the building energy loads. The other program, GEMS, (Generalized Energy and Materlal Balance Simulation developed at the University of Idaho) (6) was used to examine the response of the heating system to the bullding loads. In order to generalize the results, several types of heating systems were analyzed in an effort to determine which items were unique to a particular system and which items were generally true. The 
economics of equipment selection, bullding system retrofte, and geothermal distrlct heating systems are also discussed. As with any econonic study the results determined are based on a number of assumptions; in this case these assumptions include future energy costs, system geography, and governmental Incentives. The economic results should be examined in light of the assumptions and careful consideration should also be glven to noneconomic aspects such as pollution, energy self sufflclency, aesethics, and community response. For the actual bulldings and heating systems we have modeled, we have found that implementation of the design and operating guidelines outlined In this document typically result in cost savings on the order of $50 \%$ in the delivery price of energy derived from geothermal water.

\subsection{MODELING OF GEOTHERMAL HEATING SYSTEMS}

The development of a completely theoretical model of a bullding and the bullding heating system is an extremely difficult task. In order to 11lustrate the complexity of this problem it is convenient to examine the terms that are required to complete the overall materlal and energy balances that describe the system operation. Equation (1) is a general statement of the mass balance for a system.

$\begin{aligned} & \text { Rate of } \\ & \text { Mass IN }-\quad \begin{array}{l}\text { Rate of } \\ \text { Mass OUT }\end{array} \quad+\text { Rate of } \\ & \text { Mass GENERATION }\end{aligned}=\begin{aligned} & \text { Rate of } \\ & \text { Mass ACCUMULATION }\end{aligned}$

For a building heating system the terms of equation (1) for the a1r flow through the bullding are easily identifled but not always easy to quantify; in addition to the fresh air supplled through the heating system, alr is transported Into and out of the building through doors, windows, cracks around doors and windows, fresh afr Intake louvers, and exhaust a1r louvers. There 
Is no generation of mass within the building and the accumulation of alr within the bullding can be identffled as changes in air pressure and temperature. These changes are small and can be neglected when compared with the errors in determining the inlet and outlet terms. Equation (2) is a general statement of the energy balance for a system.
2).
Rate of
Rate of
Energy IN
Energy OUT
$+\underset{\text { Genergation }}{\text { Energy }}=$
Rate of
Energy ACCUMULATION

For a bullding heating system, the terms in the energy balance (Equation 2) are more numerous. Energy is transported into and out of the bullding by three different mechanisms; conduction, convection, and radiation. Energy conduction occurs through walls, windows, doors, basement floor and walls, and the roof. Transport by convection involves the same terms as stated through exterior glass, absorption by interfor surfaces, and the subsequent re-emission by these surfaces as heat energy. Energy is generated within the bullding by occupants, 11ghting, equipment, and the heating system. Energy is accumulated in the bullding structure, room contents, and bullding alr. The numerical amount of each of these terms is not easily calculated and many of the terms are interrelated. For example, the solar energy Input is dependent on the time of day, time of year, geographic location, cloud cover, and shading from surrounding bulldings, trees, etc. The amount of energy conducted through a wall is dependent on the exterior temperature, Interfor temperature, wind velocity and direction, solar radiation reaching the exterlor wall surface, as well as the present temperature gradient within the wall. The energy supplied to the bullding heating system is dependent on the Individual thermostat responses, heat exchanger operation, system design, and operating procedure. Obviously, any 
model that is compact enough to be used as an analysis tool will require many simplifications.

Fortunately, a great many simplifications can be made without a significant loss in the model accuracy for the basic transient response and heat loss prediction. In general, an extremely complex model of the bullding heating load may only be within about $10 \%$ of the actual value. Since seasonal and year to year weather conditions vary greatly this amount of error is quite acceptable.

In reducing the model complextty, the amount of error does not change significantly. What does change is the amount of information predicted by the model. For instance, a bullding with 20 individually controlled heating zones can be modeled as such to determine information concerning individual alr flow requirements for each zone. This information is important for the design of ducts and terminal units but is not required for an overall analysis of the geothermal heating system.

For an approximate optimization of a geothermal heating system design and operation, the degree of model complexity can be determined by tracing the required Information through the system. First, the key to minimizing the geothermal flow centers on minimizing the geothermal discharge temperature. Therefore, information relating to the operation of the geothermal water heat exchanger is of primary 1mportance.

In some systems, the geothermal water is so clean and non-corrosive that it can be used directly in the alr-water heat-exchanger (Figure 3a); more often a secondary fluid is used to isolate the alr heat exchanger for the corrosive and fouling characteristics of the geothermal water (Figure $3 b$ ). In. this case, the Interaction of these two heat exchangers will determine the geothermal discharge temperature, and therefore they must be modeled together 


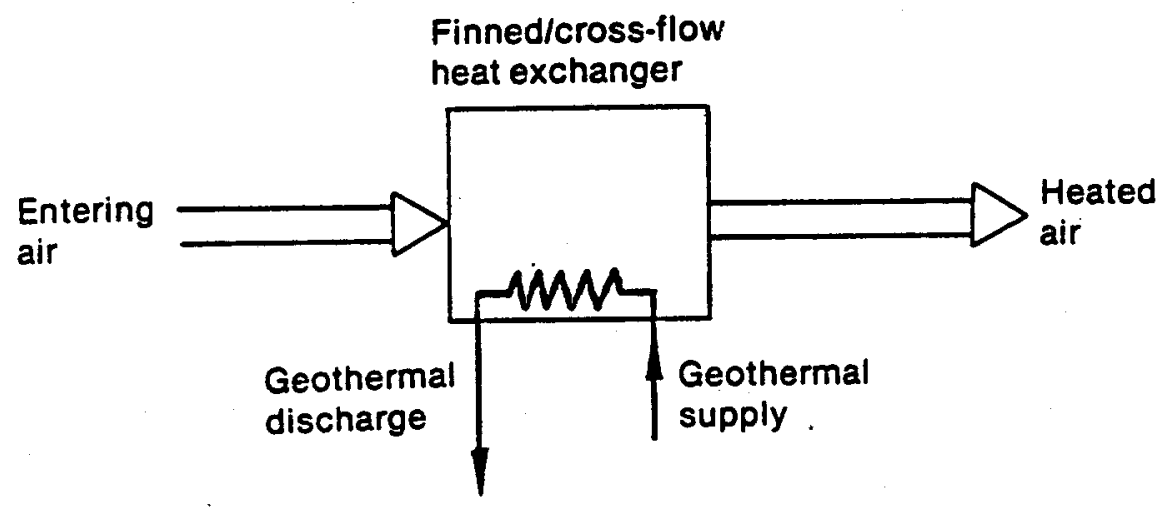

FIGURE 3a. Direct transfer to air

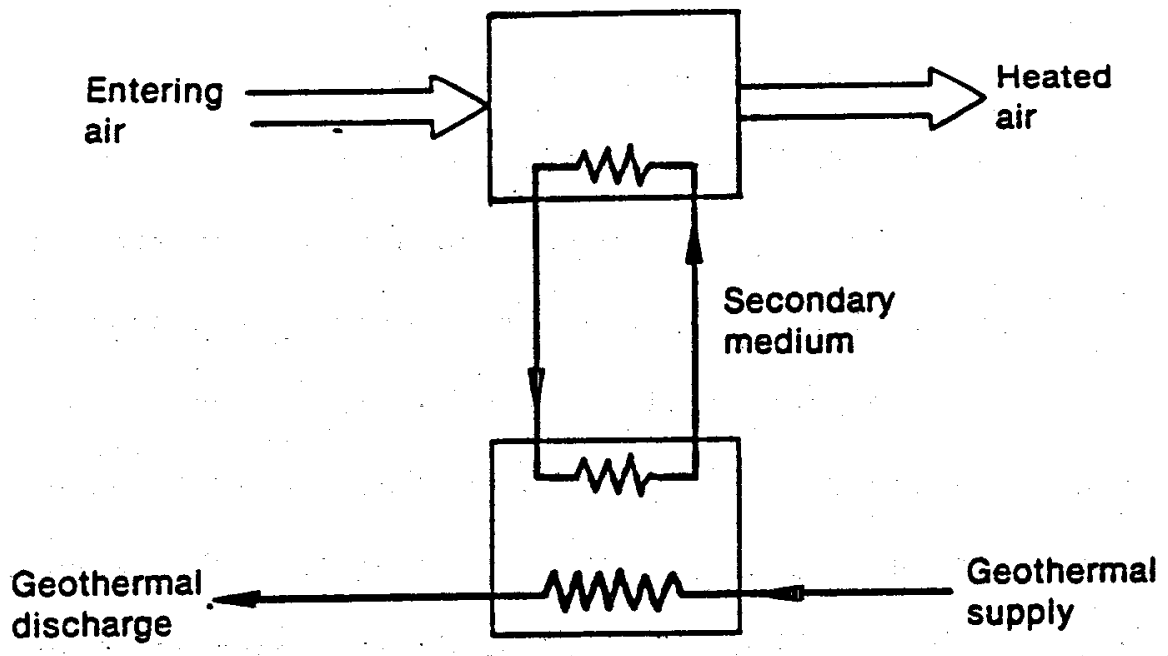

FIGURE 3b. Indirect heat transfer to air 
in order to determine the optimum operation.

The next information required concerns air flow and temperature, which are primarily determined by the bullding load and operational strategy. The bullding response is not dependent on how the alr is heated, and only the resultant temperature and flow are important.

\subsection{INDIVIDUAL SYSTEM ANALYSIS}

The following sections describe the operation of several types of heating systems with respect to geothermal water usage. The heating systems analyzed represent each of the main classifications but do not cover all of the possible options. Tamami Kusuda (7) mentions 26 different types of heating systems that represent those common1y used in modern bulldings. Many of these systems are similar or are comprised of a combination of two other systems (for instance variable air volume VAV, vs. VAV with terminal reheat). The systems analyzed in this document are representative of the basic system types: variable air volume, dual duct, terminal reheat, fan colls, etc. As stated previously, the optimization of geothermal heating system implies minimizing the geothermal water discharge temperature. Each of the systems was examined to determine the optimum methods of control and operation.

All geothermal space heating systems can be divided between two categories, direct and indirect. In the first category are systems which transfer the energy in the geothermal water directly to the space air (Figure 3a). In the second category are those systems that transfer the energy from the geothermal water to a secondary medium and then from this secondary medium to the space air (Figure $3 b$ ). Optimization of direct heat exchange systems is very straightforward, while indirect systems are more complicated.

In the following sections each heating system will be examined for optimum design based on the indirect heat exchange mode. Results pertaining to the 
optimum loop water flow rate or the optimum size for a water/water heat exchanger do not apply to a direct heat exchange system, however, the results that Indicate the best air flows, supply air temperatures, the air/water heat exchangers are the same for both direct and Indirect heat exchange.

Control of energy to the air/water heat exchanger is usually achleved in one of two ways:

1) Throttle the amount of geothermal water passing through the primary heat exchanger (FIgure 4a)

2) Bypass some of the secondary flow around the alr-water heat exchanger through a 3 -way mixing valve (Figure $4 \mathrm{~b}$ ).

The first method provides for more efficient use of the geothermal energy, as the second method results in a higher discharge temperature, as high temperature energy is bypassed to the discharge side of the system. Even if the geothermal water is further used downstream the quality of the geothermal water has been decreased. In geothermal hot water heating systems the avallable temperature is essential to efficlent operation and should not be reduced in this manner.

There are advantages in going to a direct use system, including decreased Investment costs and decreased operating costs as 11sted below.

1) No pumping costs for the loop water.

2) No water/water heat exchanger capital expense.

3) Lower geothermal water use because there are no $T$ losses in the loop system.

The primary disadvantages are corrosion and scaling occurring in the air/water heat exchanger Instead of occurring in the water/water heat exchanger. In general, plate type heat exchangers are used for the 


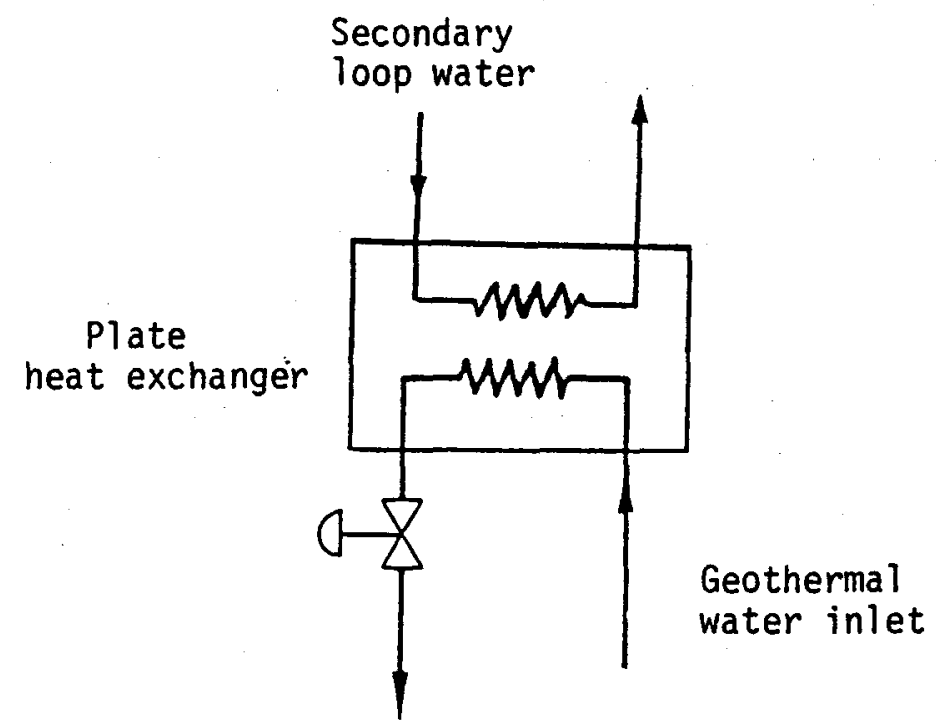

FIGURE 4a. Control of delivered energy by throttling the geothermal water flow

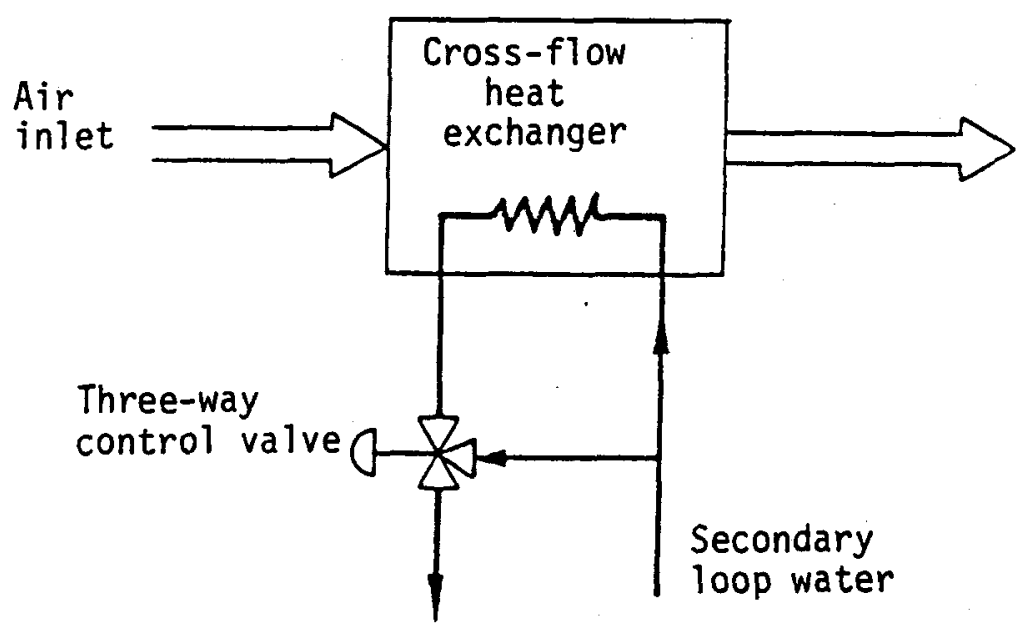

FIGURE 4b. Control of delivered energy using a three-way mixing valve 
water/water heat exchangers. These exchangers are easier to clean than the cross-flow exchangers and the costs for additional corrosion resistance (higher quality materials) are lower for the same heat transfer. Also, the turbulance in plate type heat exchangers is higher which reduces the amount of scaling. The determination between direct and Indirect heat exchange will depend primarily on the expected quality of geotheraml water. Indirect heating systems typlcally use copper tubes in the alr-water heat exchangers, and stainless steel in the primary plate heat exchangers.

\subsection{SYSTEM 1: VARIABLE AIR VOLUME}

Heating System Description

The central heating system shown in Figure 5 supplies the bullding with two main alr sources. The hot duct supplies a constant volume of warm alr to the bullding perimeter. The cold duct supplies a varlable volume of cool air to the interior bullding zones. The system is intended for use with large office bullding or other structures that have the following characteristics:

1) Large interior space that requires cooling throughout the heating season

2) The exterior zones require some heating to offset losses due to convection and conduction

3) The bulldup is open enough to allow air circulation to exterior zones

The exterior areas may extend 12 to 20 feet Inward from the outside wall (8) and are subjected to heating loads from conduction through the walls, convection around windows, and conduction through the windows. The difference In solar loads between the north and south exposures may be great enough to require separate systems and will certainly require separate design considerations. 


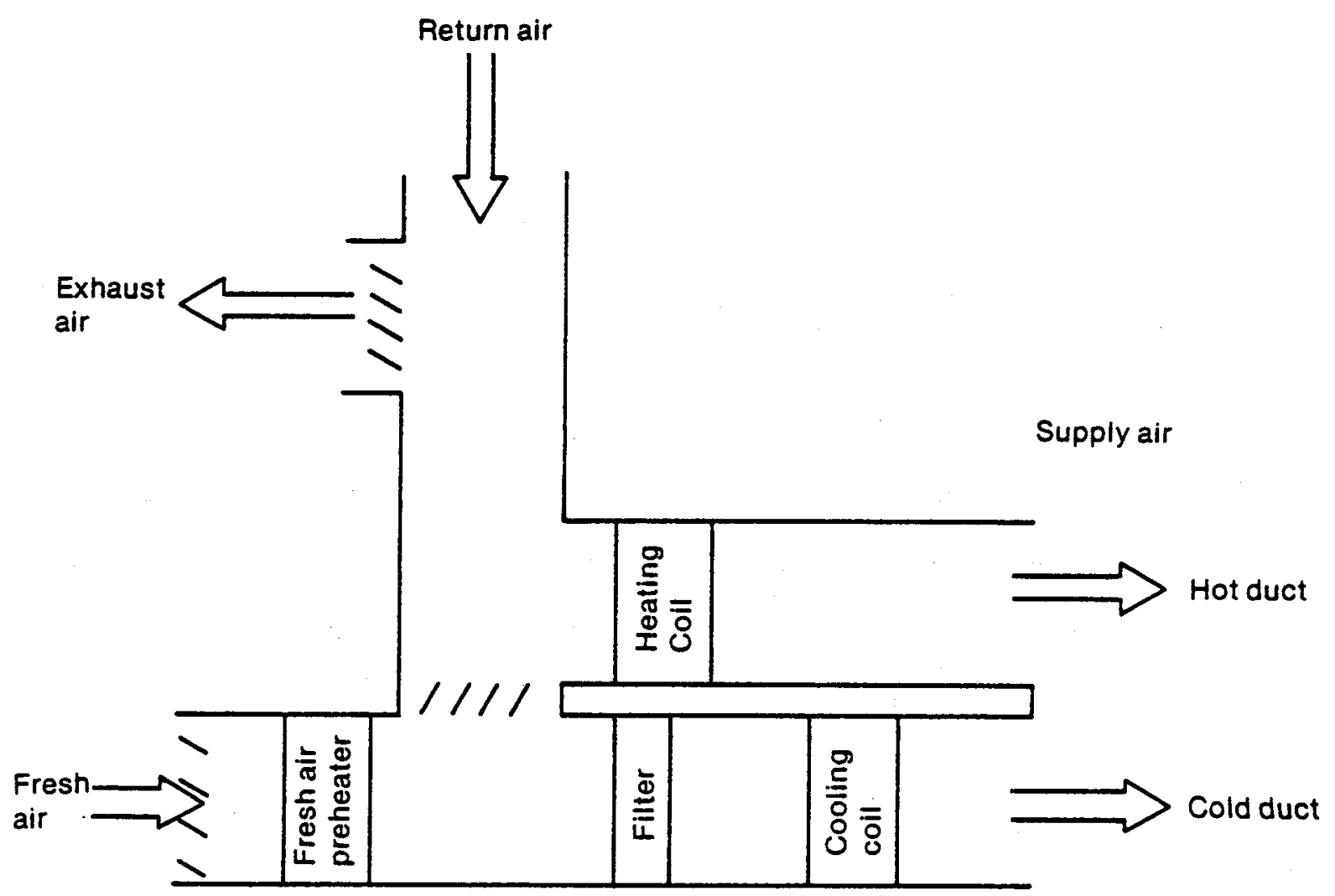

FIGURE 5. Variable Air Volume System With Hot and Cold Ducts 
Generally, the warm air is supplied to the exterior zones through the floor near the walls, this allows alr cooled by the wall surface to be mixed wth warm air before entering the main area of the zone. Temperature control is achleved by variable volume terminal units supplying cold air to the same zone. Some areas of the building may require more heating and/or temperature control than is provided by the perimeter supply of hot alr (such as the top floor which has heat loss through the roof), this heating demand can be met by hot-water reheat colls located on the variable alr volume mixing boxes. General Control Methods

The zone temperature is controlled by a thermostat that operates the damper in the variable alr volume terminal unit. The temperature in zones that have terminal reheat units are controlled by a thermostat that controls In sequence the terminal untt alr damper and a three way mixing valve on the reheat coil. Alr flow through the terminal unit is decreased as less cooling is required; when heat is required the damper is maintained at the minimum position and the three-way mixing valve is adjusted to admit hot water to the heating coil (Figure 6).

Central Unit Controls

The hot deck (Figure 7) is maintalned at a constant flow and the discharge temperature is regulated by adjusting the energy supplied to the primary heating co11. The following methods can be used for control of the energy supply to the primary heating coll.1

1) The hot water flow to the $\operatorname{col} 1$ is regulated by modulating a valve on the heating coll discharge IIne (Figure $7 a$ )

2) The hot water flow to the coil is regulated by modulating a three-way mixing valve that bypassed some of the hot water around the heating coll (Figure $7 \mathrm{~b}$ ) 


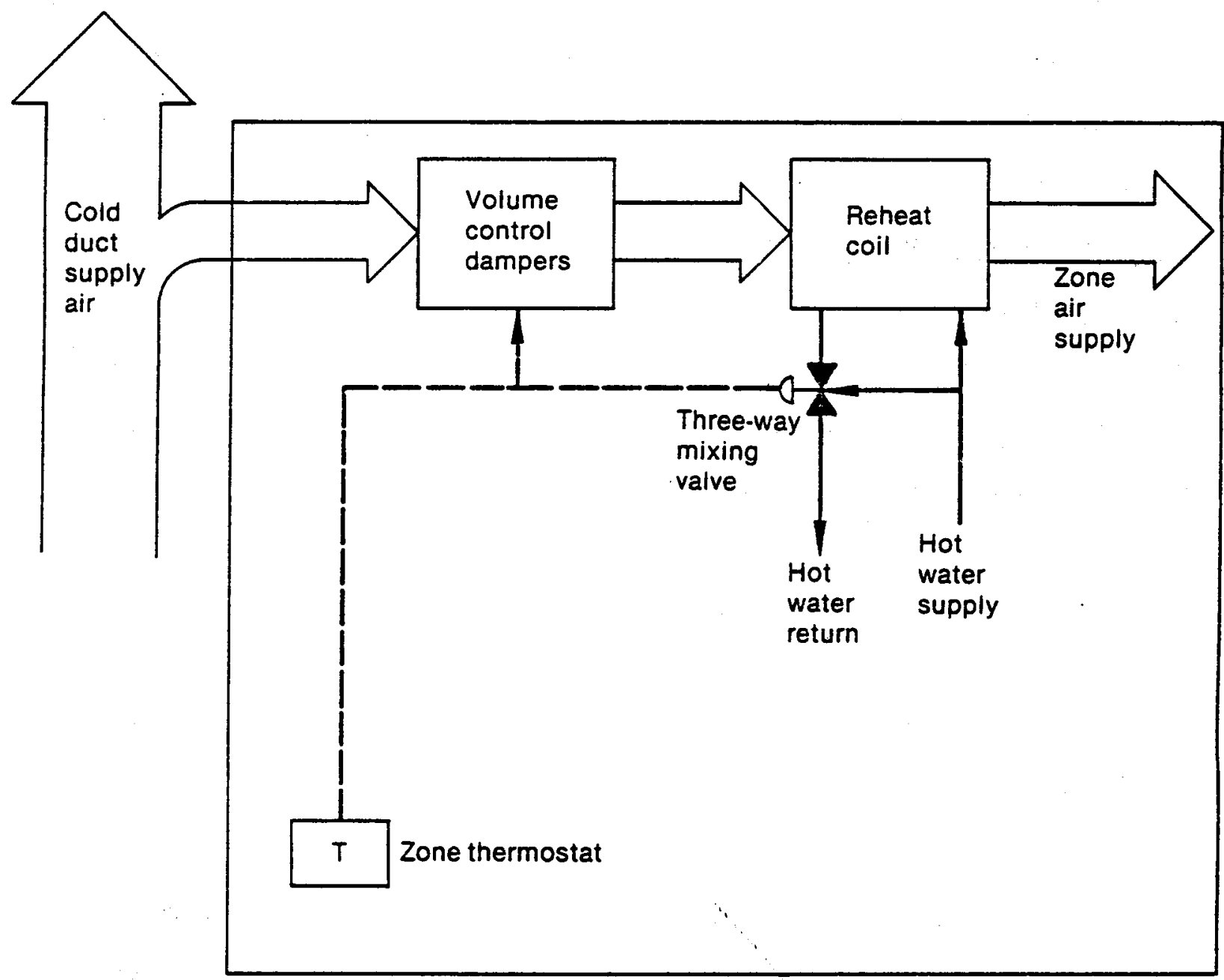

FIGURE 6. Control Operation of Terminal Reheat Coils in Variable Air Volume System 
3) A steam valve is modulated to change the steam supply to a steam heating coll (Figure 7c).

The hot deck set point is generally reset by one of the following methods.

1) Manual reset - Adfusted if occupant comfort requirements are not being met.

2) Amblent reset - The hot deck set point is Increased as the amblent temperature decreases. The reset schedule is usually a Iinear relation with a hot deck set to its maximum valve at the design condition. For instance, the following temperatures would define a typical ambient reset schedule:

$\begin{array}{cc}\text { Ambient Temperature } & \text { Hot Deck Set Point } \\ 0 \mathrm{~F} & 140 \mathrm{~F} \\ 70 \mathrm{~F} & 70 \mathrm{~F}\end{array}$

3) Set to minimum using a zone comparator controller which passes through the signal from the zone requiring the most heat with respect the the maximum avallable for that zone.

The cold deck temperature is maintained at the set point by modulating the return, exhaust, and fresh alr dampers. The exhaust and fresh air dampers are generally interconnected such that the amount of fresh alr admitted just equals the amount of air exhausted, any difference results in a silght positive or negative pressure inside the bullding. During the heating season the cooling coll (Figure .5) is not required, and adjustment of the fresh and exhaust a1r flows is used to Increase or decrease the cold deck temperature. The cold deck set point is usually manually set between $55 \mathrm{~F}$ and $60 \mathrm{~F}$ and is usually adjusted seasonally; for instance the temperature is set higher in the winter when the cooling loads are low. 


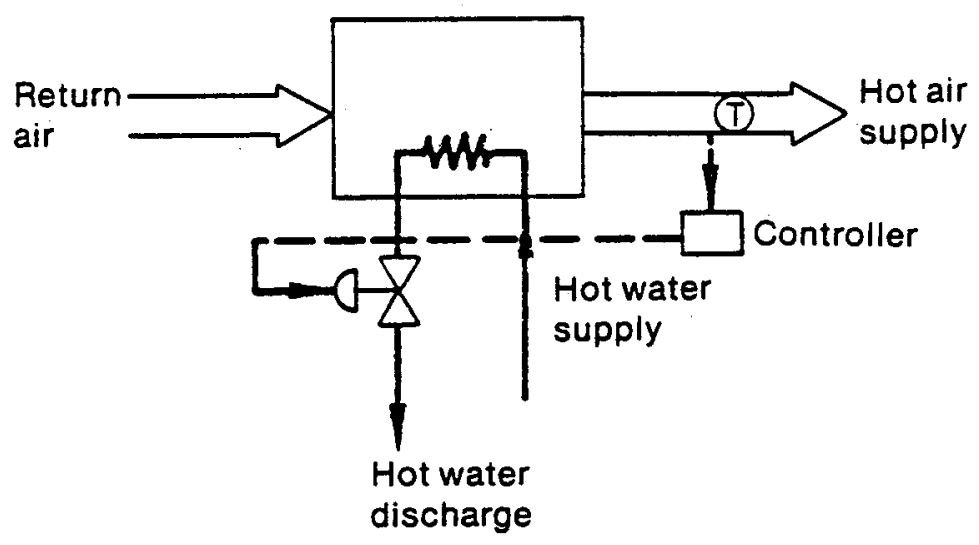

(a) Variable hot water flow

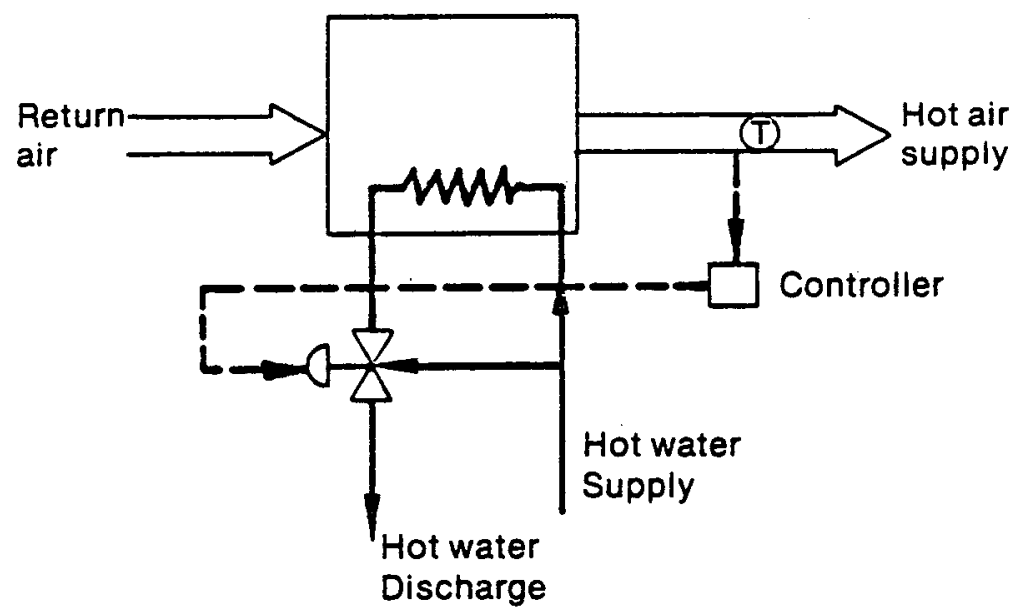

(b) Three way mixing valve

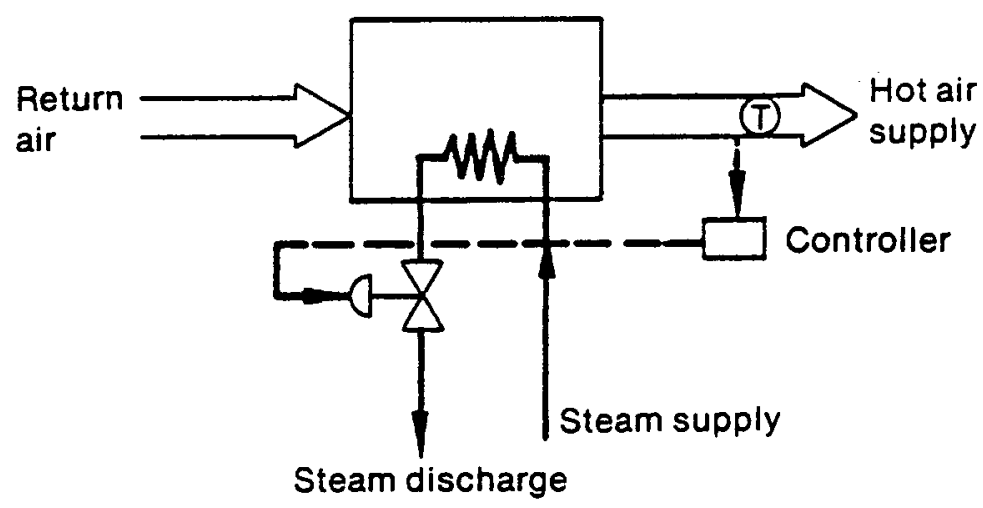

(c) Steam heating coil

FIGURE 7. Energy Control Methods for Terminal Reheat Coils 


\section{System 1 Analysis}

The analysis of this heating system was based on "generic" structure and heating equipment design. A $100,000 \mathrm{sq}$ ft office building requiring 100,000 cfm of total air flow and a minimum of 15,000 cfm fresh air was chosen for the structure. The air/water heat exchanger was designed using manufacturer suggestions for a design heating load (at 0 F) of $2.0(10.6) \mathrm{BTU} / \mathrm{hr}$ and an alr flow of $31,500 \mathrm{cfm}$. The water/water heat exchanger was designed using the manufacturers suggestions for a plate-type heat exchanger. The design conditions at $0 \mathrm{~F}$ were:

1) Geothermal water Supply temperature $=165 \mathrm{E}$

2) Loop water

$$
\text { Supply temperature }=160 \mathrm{~F}
$$

3) Loop water

$$
\text { Return temperature }=130 \mathrm{~F}
$$

4) Loop flow as determined by air-water heat ex. design

The system was operated at a constant loop water flow rate (although varlous magnitudes of this flow were investigated) and the hot deck temperature required to meet a specifled demand was obtalned by throttilng the geothermal water flow rate.

\section{Loop Water Flow Optimlzation}

Figure 8 shows the varlation of geothermal water flow rate with loop water flow rate for varlous hot deck supply temperatures. Notlce that at higher hot deck temperatures (colder weather conditions) the suggested design point indicates a loop water flow that is somewhat lower than it should be.

The best operation, with respect to geothermal water use, is obtained by operating to the right of the steep portion of the curves where loop water flow has little effect on the geothermal flow. For a low hot deck temperature 


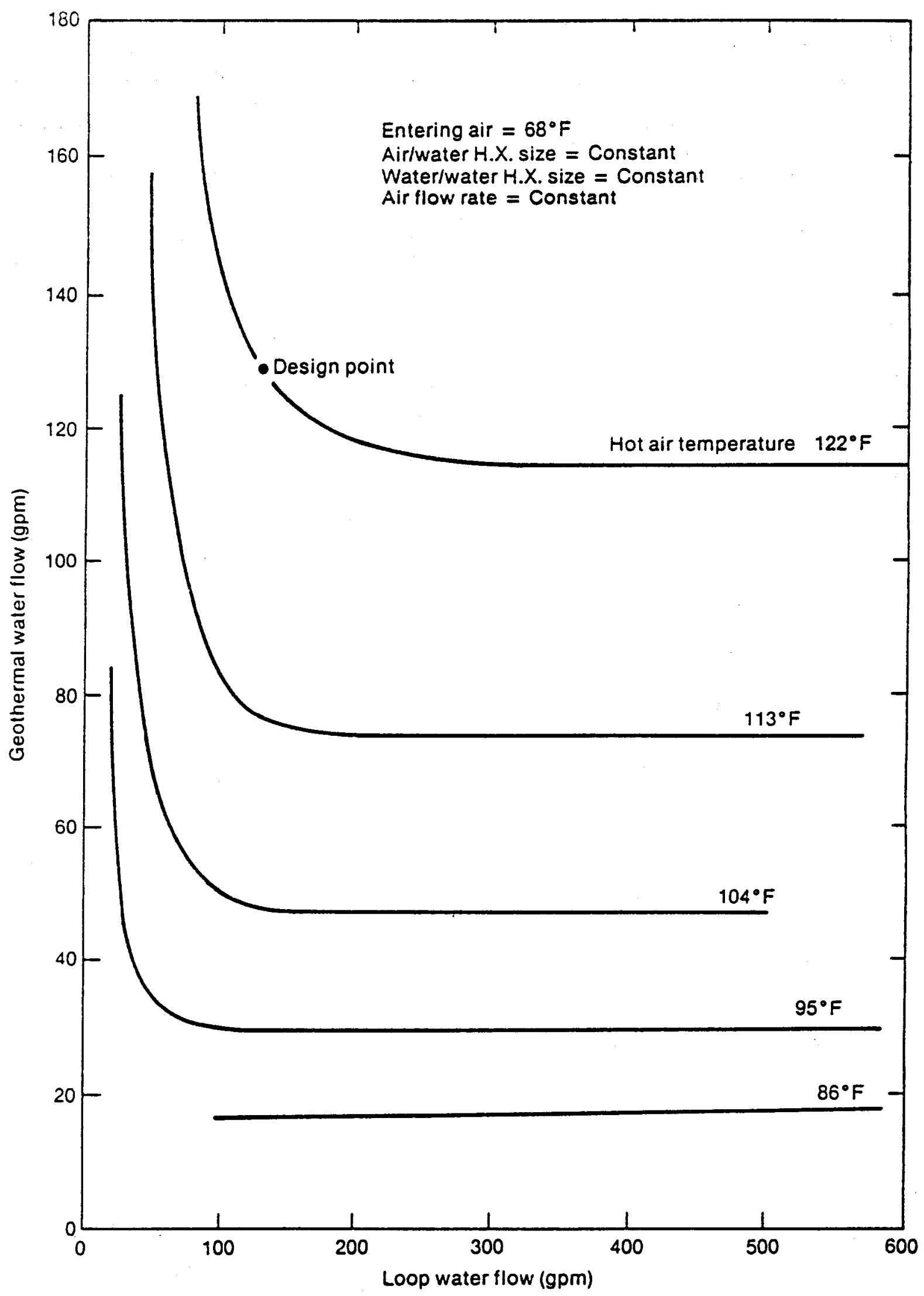

FIGURE 8. Changes in Required Geothermal Flow as a Function of Loop Water Flow at Various Heating Loads 
(low heating demand) the design loop water flow is satisfactory. For higher hot deck temperature, a flow rate greater than the design loop water flow rate is recommended. Since the costs of Increasing the loop water flow are minimal, it is advantageous to operate the system at a loop water flow rate approximately $50 \%$ greater than the design value typically recommended by equipment manufacturers: Air-Water Heat Exchanger Size

Figure 9 shows the effect of changing the size of the alr-water heat exchanger on geothermal flow.

The heating demand and resultant flow are for the office structure described in Section 2.0. As the ambient temperature decreases, and the corresponding heating load increases, the effect of heat exchanger size Increases dramatically. At a heating load corresponding to an ambient temperature of $2.5 \mathrm{~F}$ a $50 \%$ decrease in heat exchanger size results in a $40 \%$ Increase in geothermal use, while a $100 \%$ increase in heat exchanger size only decreases the geothermal flow by $9 \%$. At heating load corresponding to an amblent temperature at $30 \mathrm{~F}$ these changes in heat exchanger size result in a 13\% increase and a $5 \%$ decrease in geothermal water flow.

The optimum heat exchanger size is determined by the economics for a particular application, which will be strongly influenced by the expected amblent temperatures for the design location. These economic considerations are examined in detall in Section 3.0.

Plate Heat Exchanger Size

Figure 10 shows the effect of plate heat exchanger size on geothermal water requirements. The results are simflar to those obtained for the a1r/water heat exchanger size analysis. For a $100 \%$ increase in heat exchanger size, at a heating load corresponding to an ambient temperature of 


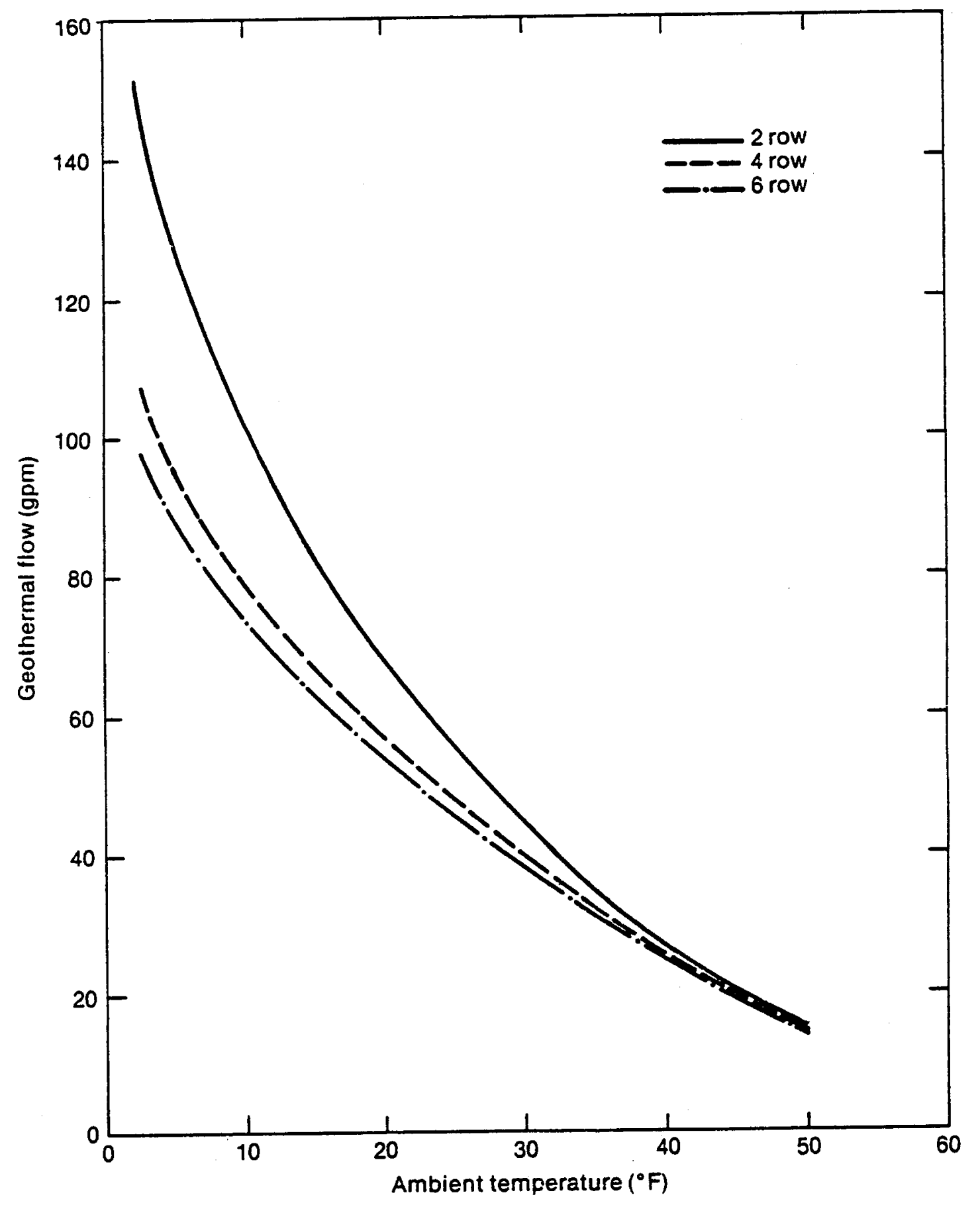

FIGURE 9. Geothermal Flow Variations as a Function of Air-Water Heat Exchanger Design 


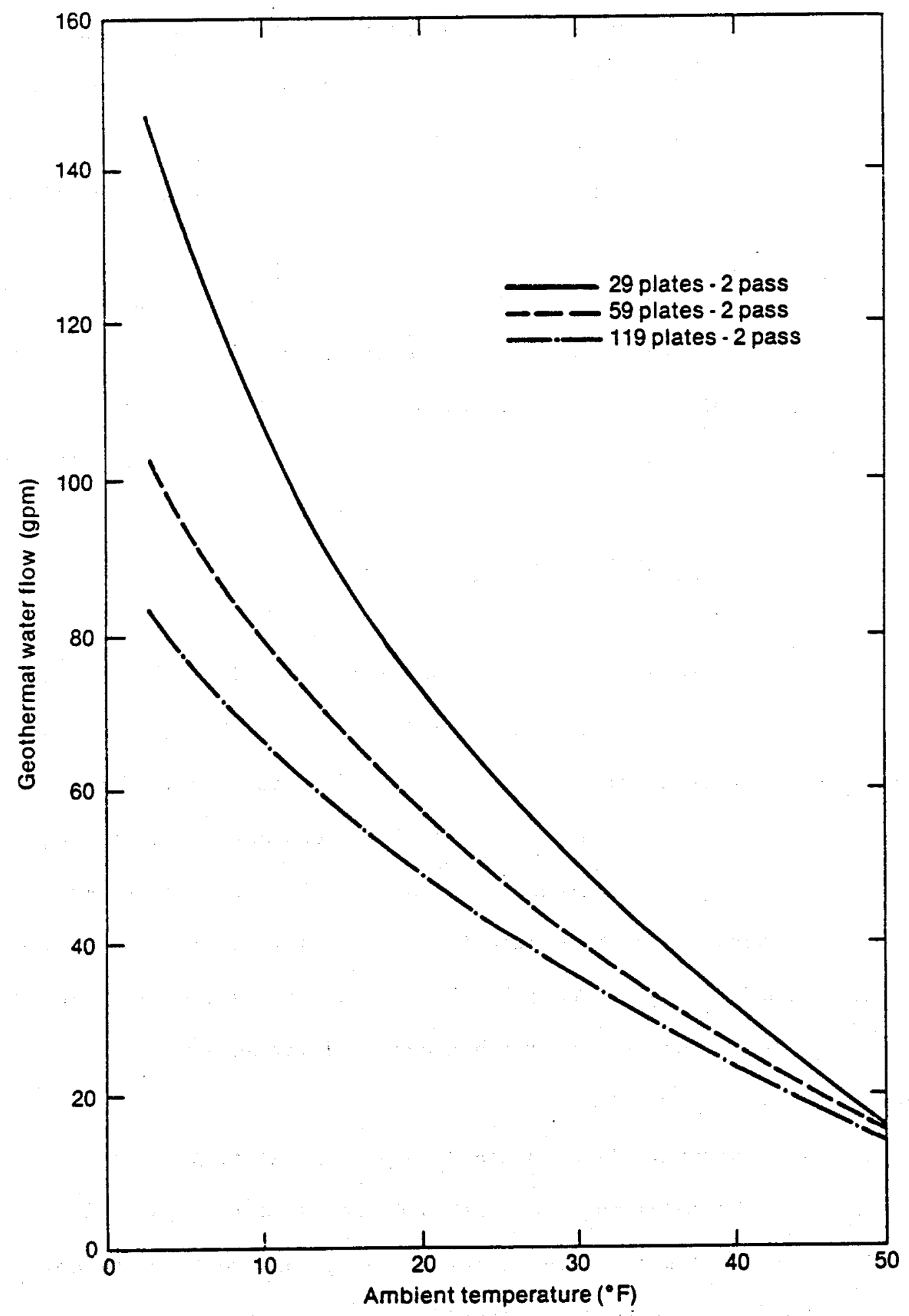

FIGURE 10. Geothermal Flow Variations as a Function of Plate Heat Exchanger Design 
$2.5 \mathrm{~F}$, the decrease in geothermal water use was $19 \%$. For a $50 \%$ decrease in heat exchanger size at these conditions the increase in geothermal water use was $29 \%$. The changes at a heating load corresponding to an ambient temperature of $32 \mathrm{~F}$ were a $10 \%$ decrease and an $10 \%$ 1ncrease in geothermal usage.

This section is intended to show the sensitivity at geothermal flow rate to plate heat exchanger size. The actual determination of heat exchanger size must be based on economics; standard design procedures yleld a heat exchanger that is roughly the correct size but may be somewhat larger than is necessary.

\subsection{SYSTEM 2: DUAL DUCT (CONSTANT VOLUME)}

System Description

The heating system shown in Figure 11 supplies the entire bullding with two main alr sources. One duct is maintained hotter than the desired room temperature and the other is maintained at a cooler temperature. Each zone recelves a mixture of air from these streams via a constant volume mixing box, which allows for heating and cooling of all zones. The mixing boxes maintaln a constant volume of supply air while allowing a full range of mixtures, from $100 \%$ cold alr to $100 \%$ warm alr. The central unit for this system is similar to system 1 but supplies fresh alr to both hot and cold alr streams. System Control

The cold deck temperature is maintalned at a constant temperature (usually about $55 \mathrm{~F}$ ) by adjusting the fresh and exhaust alr dampers. The fresh air damper is equipped with a minimum setting and in cold weather the cold deck temperature may fall below the desired level. The hot deck recelves a portion of the mixed air as decermined by downstream air damper settings. The hot deck temperature is usually set by an amblent reset schedule or a zone comparator. 


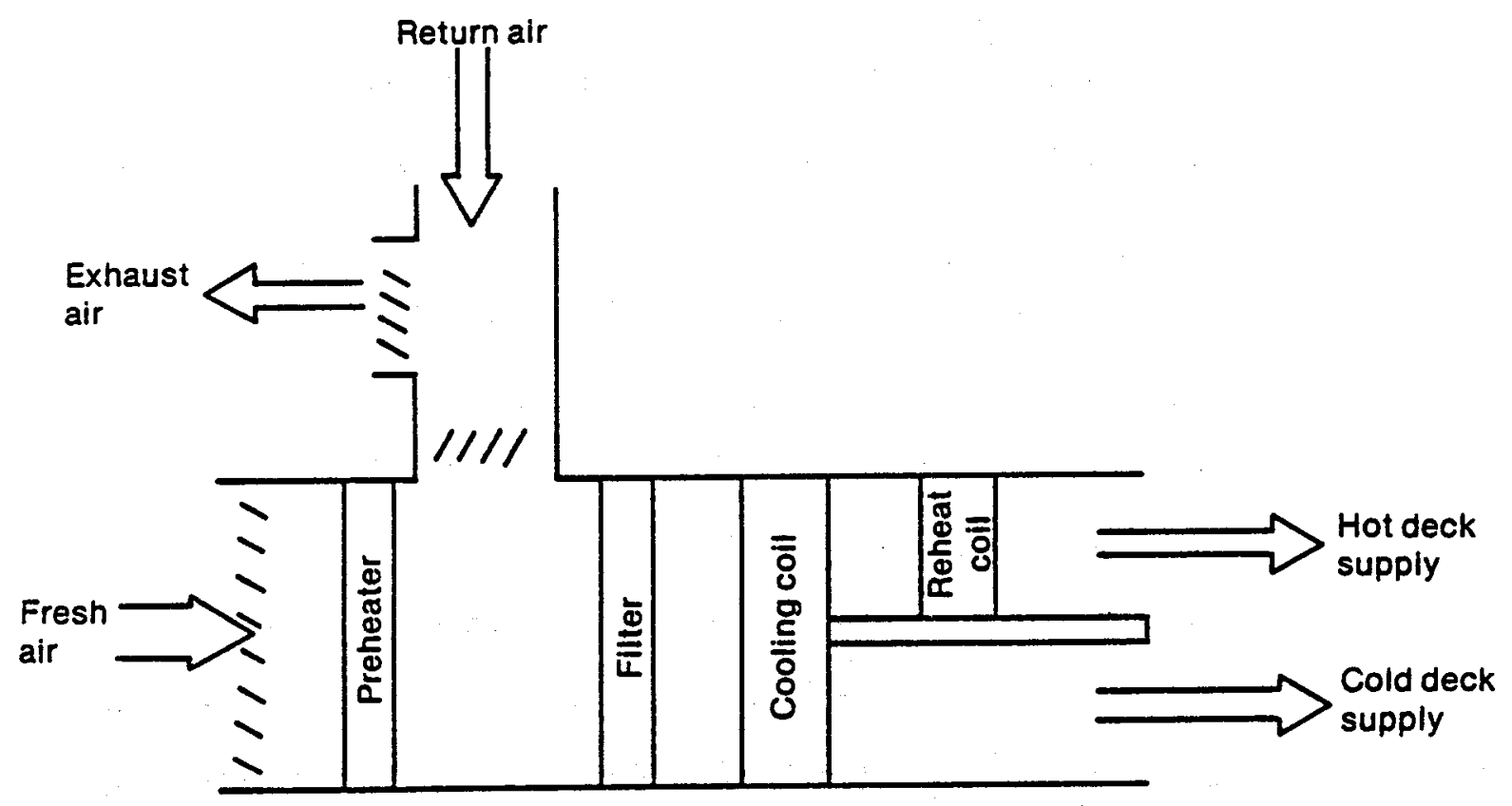

FIGURE 11. Dual Duct Constant Volume Heating System 


\section{Geotherma1 Operation}

The suggested operation for this system is very simllar to that described in Section 2.1. The loop-water flow should be set using the same guidelines and the heat exchangers should be designed according to the economic analysis discussed in Section 3.0. The primary difference between this system and that of Section 2.1 is the temperature of air supplied to the heat exchanger. This temperature is lower for this system since both the hot and cold air ducts are supplied from the mixed alr.

For a given heating load, optimum operation is obtained when the system is meeting all of the building heating, cooling, and fresh air needs and the following conditions exfst:

1) Hot Deck Temperature is as low as possible (and therefore hot deck air flow is as high as possible)

2) Cold Deck Temperature is as high as possible (and therefore fresh alr flow is minimized)

The first condition can be achleved by resetting the hot deck temperature downward until a zone comparator indicates that one zone is requesting maximum hot air (as indicated by mixing box damper position). The second condition can be achleved by resetting the cold deck temperature upward unt1l a zone comparator indicates that one zone is requesting maximum cold air (as Indicated by the mixing box damper position). The cold deck temperature control is set with a master/submaster system so that building fresh air requirements can override the zone comparator signal. 


\subsection{SYSTEM 3: VARIABLE AIR VOLUME WITH TERMINAL REHEAT}

\section{System Description}

Figure 12 shows a conventlonal varlable alr volume system with terminal reheat units. This sytem is flexible in its ability to handle simultaneously wide ranges of heating demands for different zones. The central heating unit for this system is. Identical to that of system 2 (Dual Duct) except for two features: One, the fan allows for wide variations in alr volume and two, the air exiting the cooling coll is delivered to each zone instead of being divided between two ducts. Air exiting the central unit is distributed to each zone where it is dellvered to the room via a terminal unft. Each terminal unit on the bullding perimeter contalns a heating coll and damper combination to regulate the air flow and temperature. System Contro1

The main air supply temperature is adjusted by modulating in series the fresh air and exhaust air dampers and the hot water to the main reheat coil. This temperature is determined by a number of methods, an ambient reset schedule is most common. As the amblent temperature increases (more cooling required) the mixed air temperature is reset downwards.

A zone thermostat modulates in series the afr damper control and a three way mixing valve on the water to the terminal unit heating coll (see Figure 13). The atr flow is continually decreased as the zone requires less cooling; when the minimum damper position is reached and heating is required, the 3-way mixing valve is opened to allow heating water to the coll. 


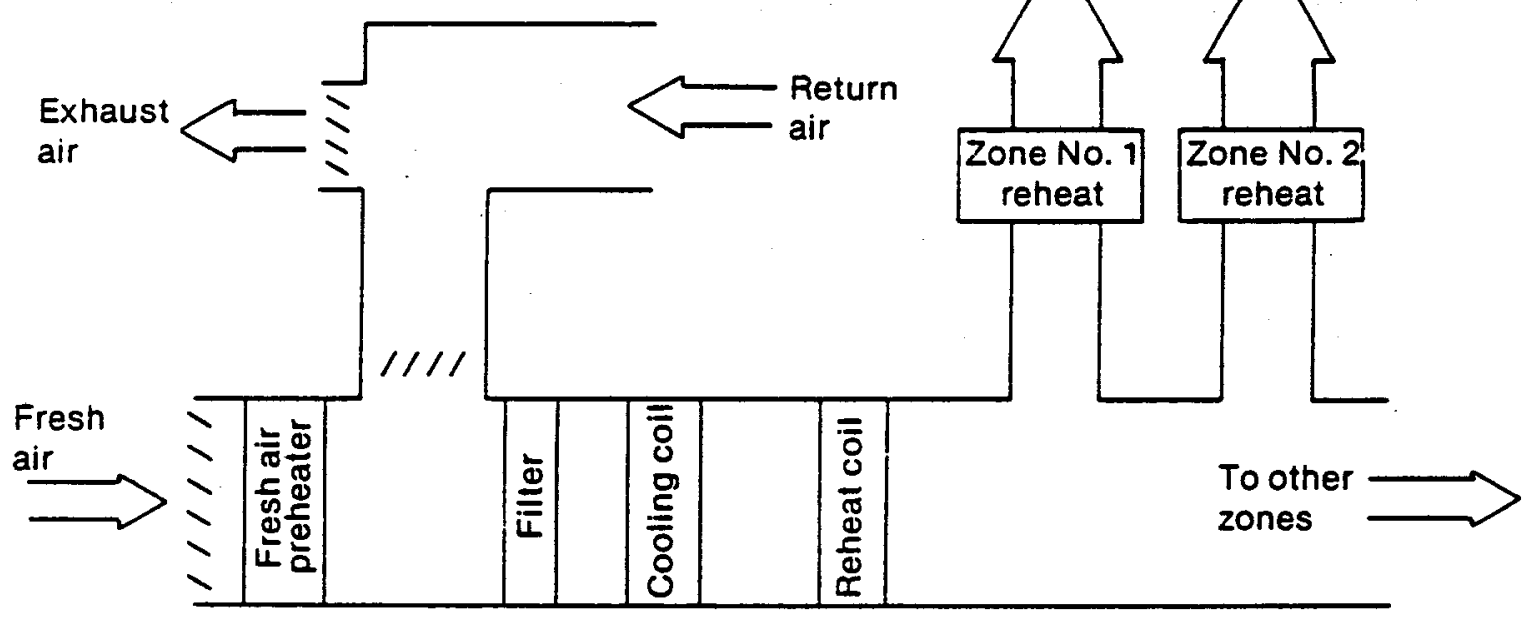

FIGURE 12. Variable Air Volume System with Terminal Reheat 
Geothermal Operation

The optimum operation for this system is similar to that for system

2: Dual Duct. The primary goals for the control system are to:

1) Minimlze fresh alr use (prevent overcooling and subsequent reheating)

2) Maximize alr flow through the system (1ncreased heat transfer rates and lower operating temperatures)

3) Maintain loop water flows that are sufficlent to minimize the geothermal water use.

Figure 13 shows a block diagram of this heating system with three zones. The distribution of heating and cooling loads is changing continualiy throughout the day, therefore at any instant in time the position of dampers and valves will be different for each zone. The zones in Figure 13 illustrate the three possible regions of operation. Zone $A$ is at minimum air flow and requesting full heat (water valve completely open). Zone $C$ is at maximum air flow (maximum cooling) with no water use. Zone $B$ is in between these and is requiring some heat, air flow is at minimum and the water valve is partially open. The most apparent problem for this system is that all heating is done at minimum air flow which is poor for efficlent heat transfer, however, this cannot be changed if the system is to provide both heating and cooling. Optimum operation is obtalned by controlling the loop water supply temperature and resetting this temperature via a zone comparator that senses the water valve positions. Again, optimum operation is achieved when one zone is requesting full heating (Zone A, Figure 13). The supply alr temperature is controlled using the same master/submaster control scheme described for the cold duct in system 2: Dual Duct. This provides a reset on the alr temperature until one zone is requesting full cooling or the master control overrides to provide the necessary fresh alr. 


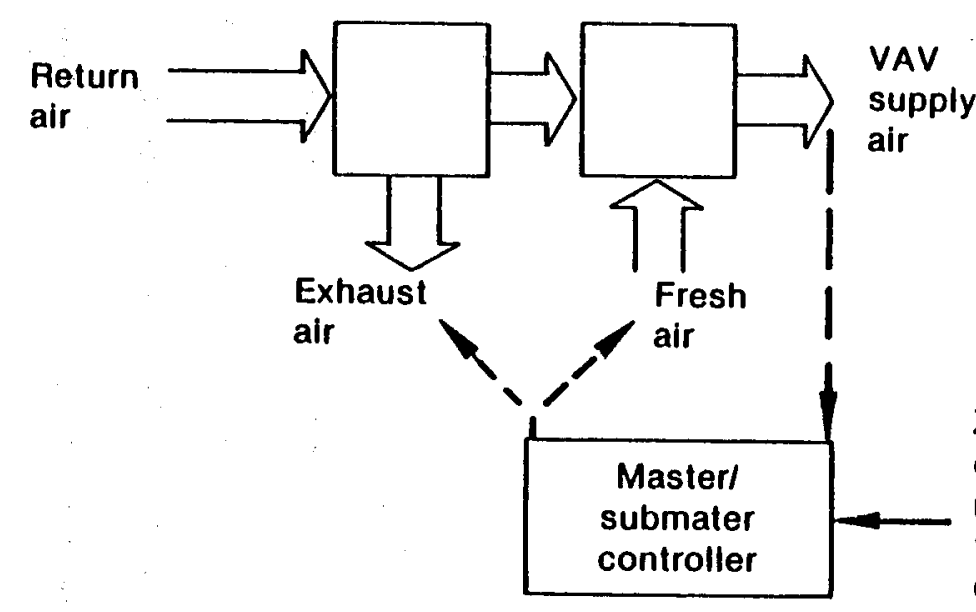

Central unit

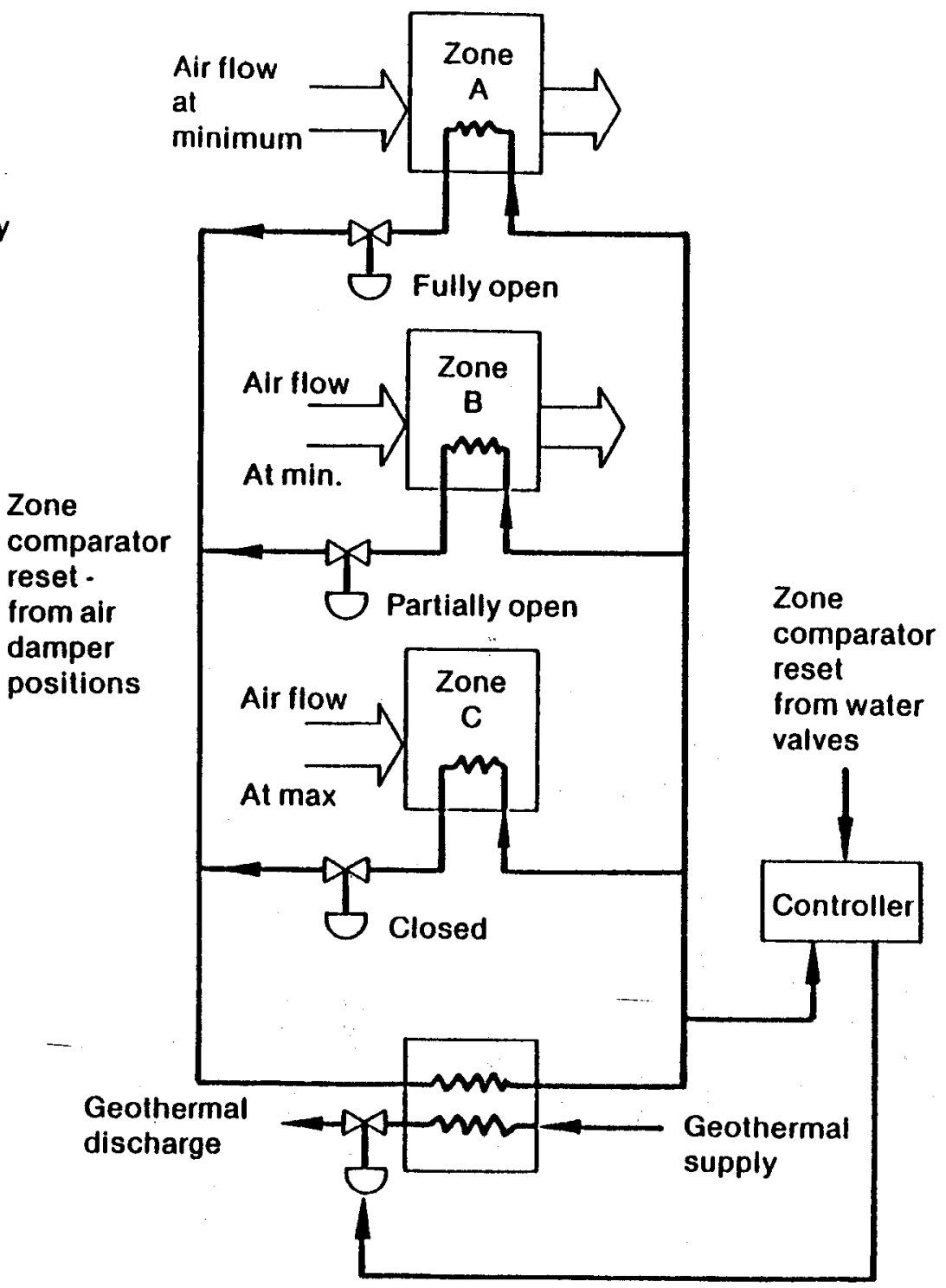

FIGURE 13. Block Diagram for VAV-Terminal Reheat System with Three Zones 


\subsection{SYSTEM 4: SINGLE ZONE FIXED VOLUME}

System Description

Figure 14 shows a conventional constant volume heating system with Face and Bypass Damper Contro1. Flgure 15 shows a conventional constant volume varlable temperature system. For the purpose of analyzing geothermal heating these two systems are Identical. The face and bypass damper system provides a more efficlent mearis of temperature and humidity control for space cooling, but, for heating these differences can be ignored. This system is designed to serve a single zone, which may be one room or a serles of rooms with very similar heating and cooling load requirements. System Control

A thermostat within the zone modulates in sequence the fresh air and exhaust air dampers, and the flow of water to the heating coil to maintain the required space temperature. The water to the heating coll may be throttled or diverted by means of a three-way mixing valve. Geothermal Operation

Optimum operation is obtained by maintaining a fixed loop water flow rate as outlined in Section 2.1 and by using heat exchangers designed with consideration for the economics outlined in Section 3.0. Figure 16 shows the deslred control strategy for this heating system. The geothermal water flow is throttled to obtain the necessary space temperature.

An equivalent control system would modulate in sequence the exhaust and fresh alr dampers and geothermal water flow to malntaln a desired outlet supply temperature. This temperature would then be reset by a signal from the room thermostat. 


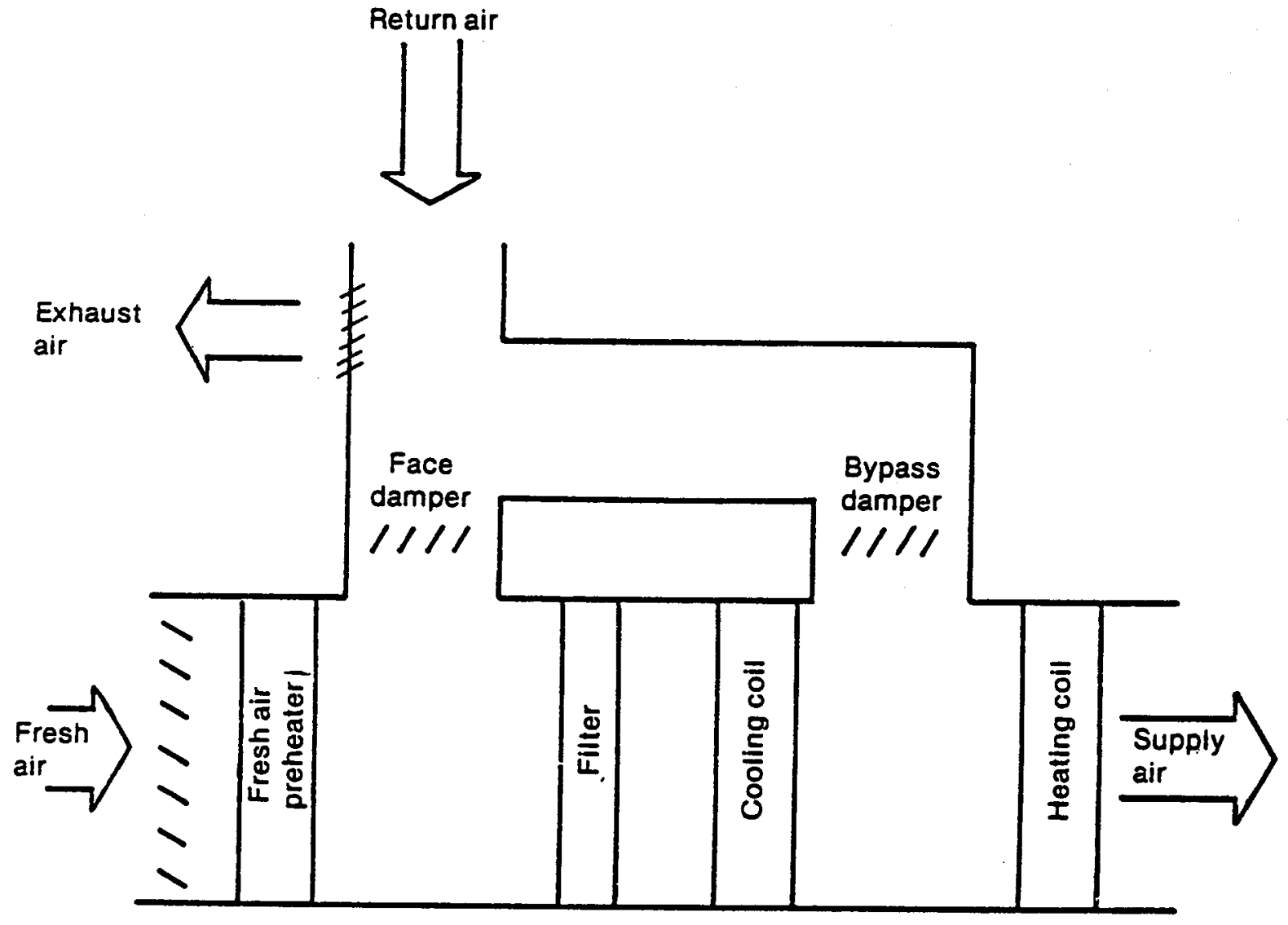

FIGURE 14. Constant Volume System with Face and Bypass Damper Control 


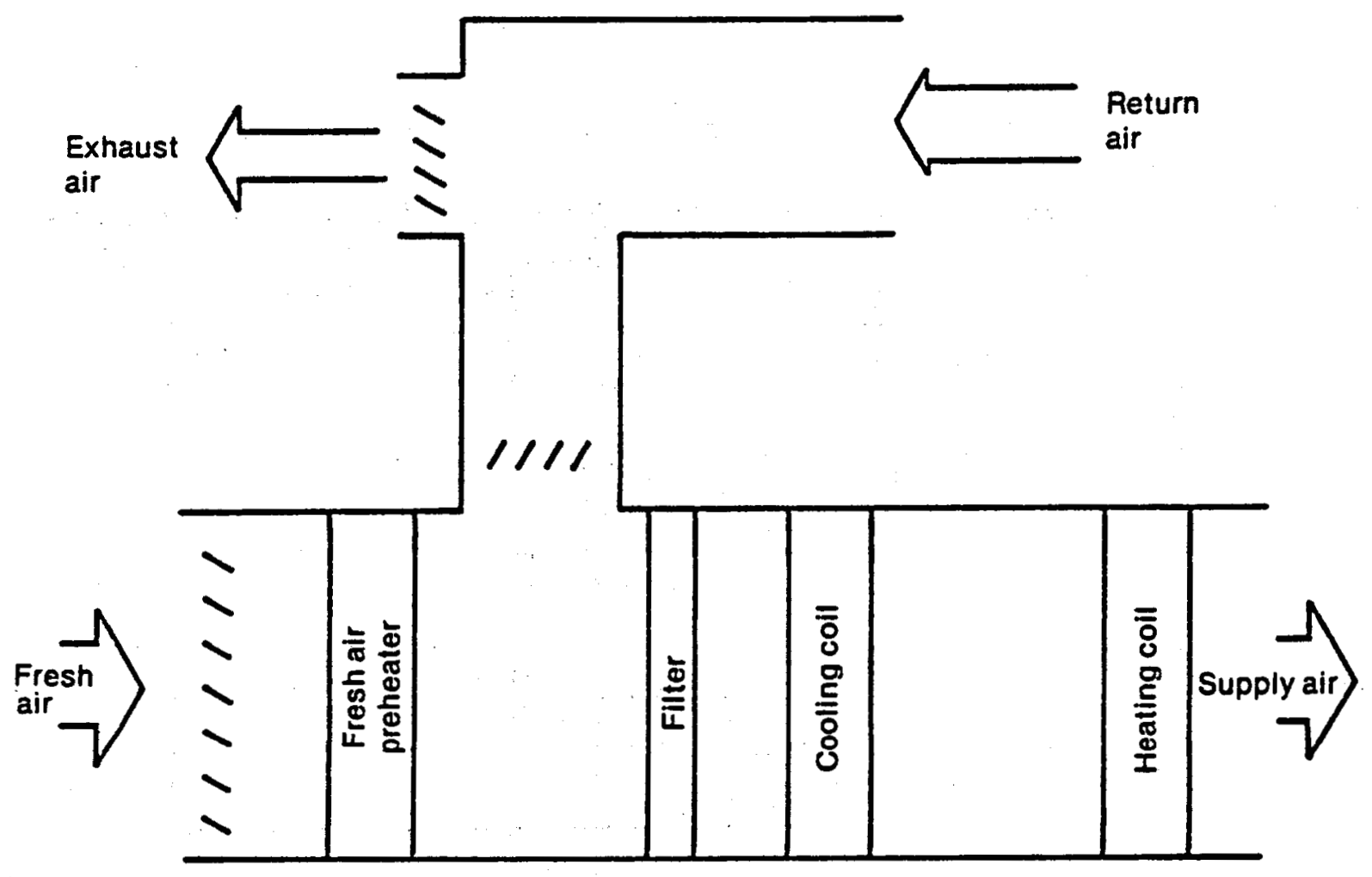

FIGURE 15. Constant Volume Variable Temperature System 


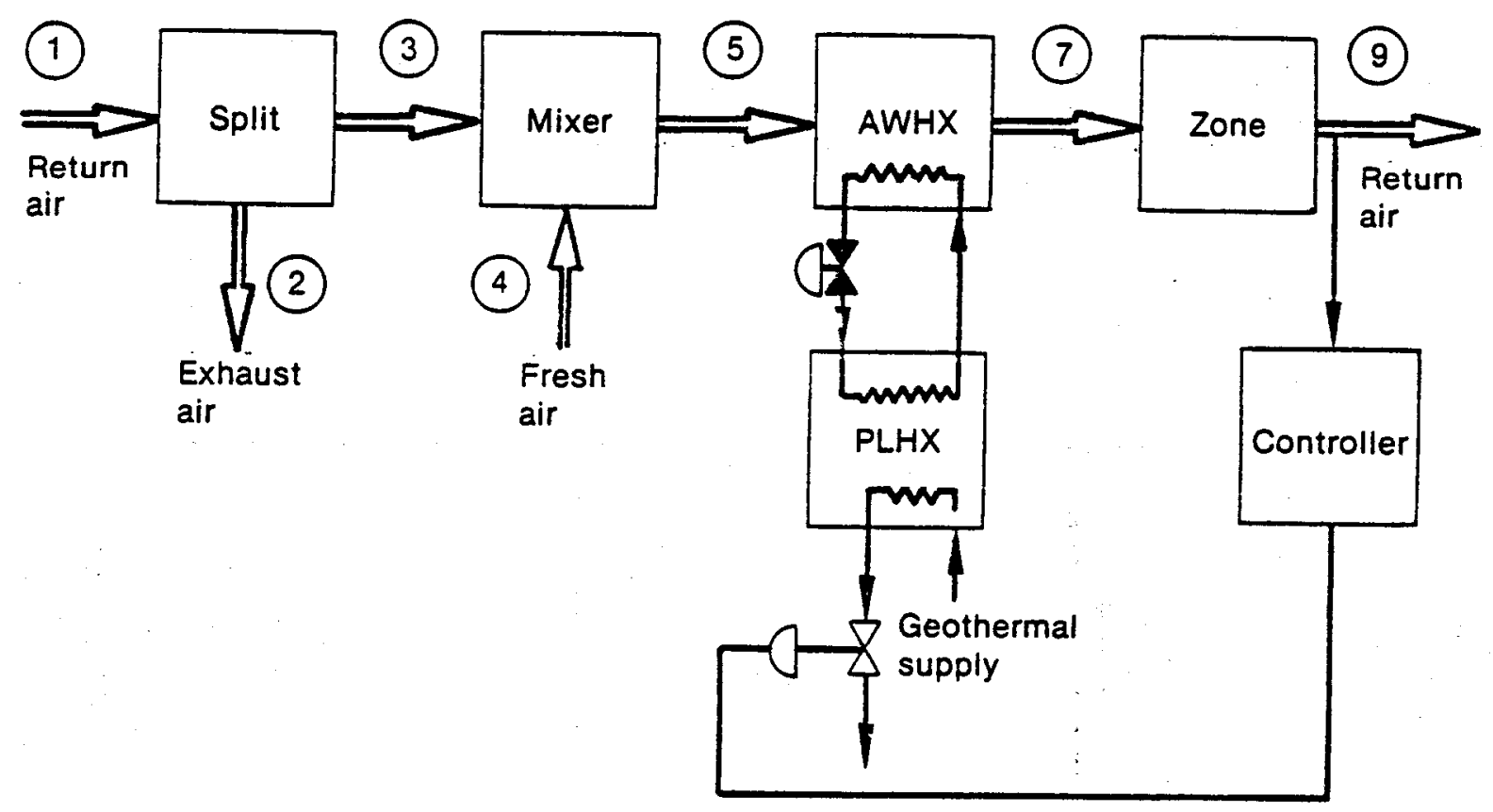

FIGURE 16. Control Strategy of Constant Volume System 


\subsection{SYSTEM 5: INDUCTION UNIT}

\section{System Operation}

Figure 17 shows a typical induction unit construction. Each zone within a heating system would contain one of these units. All of the induction units would recelve a constant volume of air from a central conditioning unft. This system is similar to system 3 (VAV with terminal reheat). The main differences are that the induction units operate from a constant volume high velocity air supply instead of a lower velocity and variable volume. The system is operated with elther cooling or heating water supplied to the Induction units. In order to provide heating to some zones and cooling to other zones it is necessary to supply all of the zones with cold air and reheat as needed.

\section{Geothermal Operation}

The optimum use of geothermal water is obtained with a1r control schemes similar to that suggested for system 3 (VAV with terminal reheat). The air supply temperature is controlled by modulating the exhaust and fresh air dampers. A zone comparator resets the supply air temperature upward (by reducing the fresh afr input) until the water valve on one induction unit is completely closed or until minimum allowable fresh air flow is reached. The fresh alr controller may override this reset to maintain space conditions. The geothermal water flow is controlled to maintain a specified loop water supply temperature. This temperature is reset downwards unt1l a zone comparator monitoring water valve positions indicates that one zone has reached a fully open position.

Loop water flow rate must be set at a level great enough that decreases in total loop water flow do not inhibit the operation of the plate heat exchangers. (See Section 2.3). 


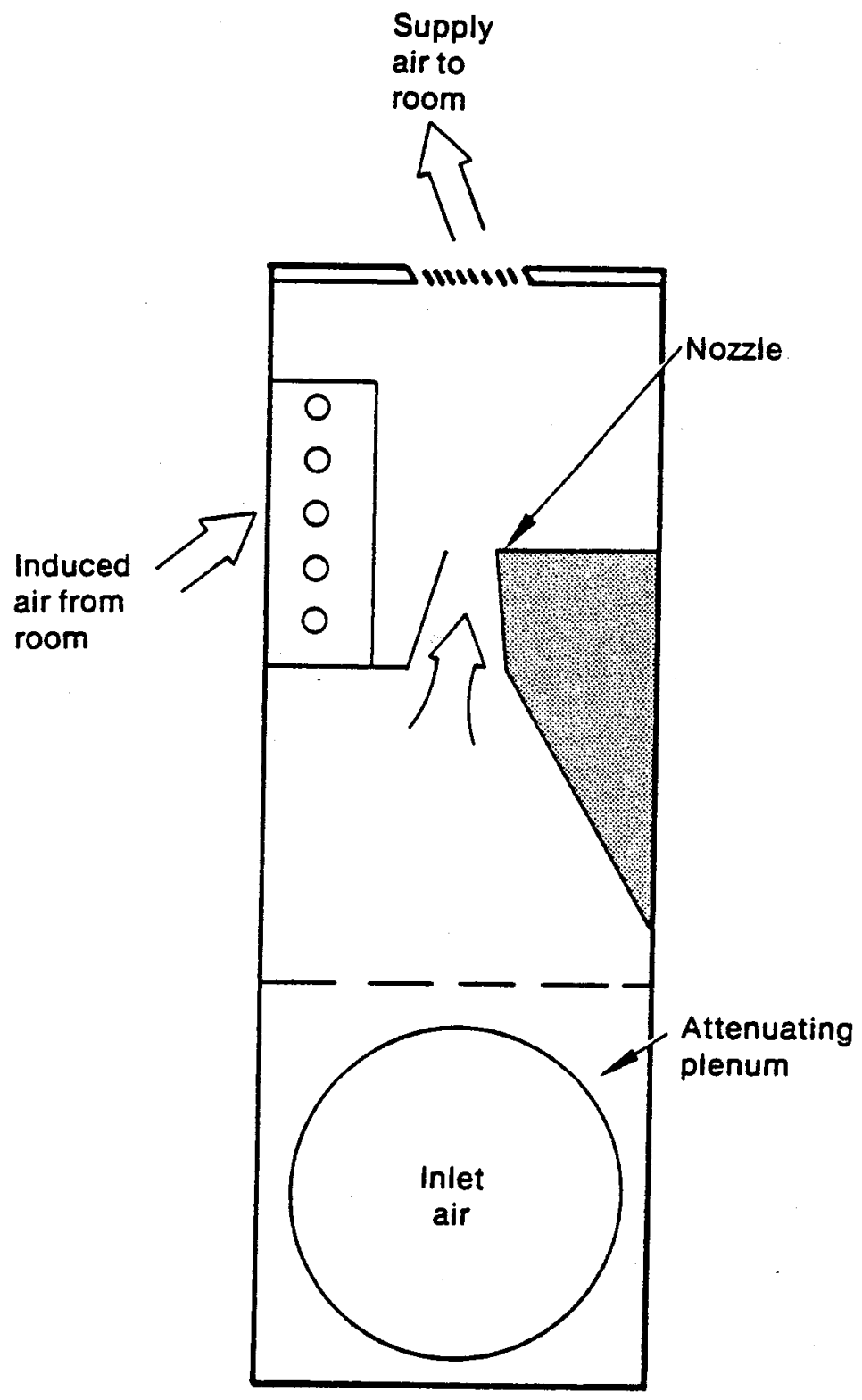

FIGURE 17. Induction Plenum and Heater 


\subsection{ECONOMIC DECISIONS IN GEOTHERMAL HEATING SYSTEMS}

Numerous methods are avallable for determining the optimum economic declslons in destgning a geothermal heating system and selecting individual equipment size, type, and material. These methods are the same as those. used Eor any economic evaluation payback time, percent return on investment (ROI), incremental ROI, discounted cash flow rate of return, venture profit, etc. The starting point in geothermal heating system economic analysis is determination of an appropriate cost for the geothermal water. Secondary problems are determining an acceptable time value of money and required rate of return.

The cost of the geothermal water can be determined by two different methods. One method bases the cost in terms of conventional energy costs and a value indicating the energy extracted per unit mass of geothermal water. For example, assume natural gas costs $\$ 2.50 /$ therm and $80 \%$ efficlency in conversion to thermal energy and 60 BTU's of energy will be extracted per pound of geothermal water (a $60 \mathrm{~F}$ temperature drop between supply and discharge). The geothermal water value is then calculated as follows:

$$
\text { VALUE }=\frac{\$ 2.50}{1,000,000 \mathrm{BTU}} \quad \frac{1}{8} \quad \frac{1 \mathrm{BTU}}{1 \mathrm{~b} F} \quad 60^{\circ} \mathrm{F} \quad \frac{62.4 \mathrm{lb}}{\mathrm{ft}^{3}}=0.01170 \$ / \mathrm{FT}^{3}
$$

or $\$ 1.17 / 100 \mathrm{ft}$

The second method bases the cost on capital recovery and required return on investment. For example, if the total capital investment is $\$ 1,000,000$, the recovery time is 10 years, the required simple ROI $1810 \%$, and the expected use is $500 \mathrm{gpm}$ for 200,000 minutes per heating season, the value is then calculaced

$$
\text { VALUE }=\frac{\$ 162,745(\text { Cost of Capital) }}{\left(500 \frac{\mathrm{Gal}}{\mathrm{Min}}\right)(200,000 \mathrm{~min})\left(\frac{\mathrm{FT}^{3}}{7.48 \mathrm{Gal}}\right)}=0.01217 \$ / \mathrm{FT}^{3}
$$


This method could also include pumping costs and additional operation and maintenance costs.

The cost of the geothermal water to the consumer will vary depending on whether the well and distribution system is constructed by a private investment group that intends to sell the water or whether the entire system is developed and installed by the end user. Also, major differences occur between private sector development and municipal development. Bloomster, et al. (9) has published a comprehensive report on the costs assoctated with the development and operation of geothermal heating systems.

Due to the variations in assigning a value to geothermal water, the following economic analysis will be based on a range of values and the results should be scaled appropriately for any given system.

\subsection{EQUIPMENT SELECTION}

The analysis in this section is based on a hypothetical office structure and heating system. The primary features of this structure and heating system are listed in Table 1 . The gearly heating load was estimated from a data base containing minimum and maximum dally temperatures for Bolse, Idaho between 1962 and $1981(10)$

In order to reduce the number of calculations required to predict yearly geothermal water usage, the following procedure was utilized:

1. A series of heating loads for the building ldentifled in Table 1 were determined for amblent temperatures ranging from 0 F to $65 \mathrm{~F}$ (see Figure 18). This does not include fresh air heating requirements.

2. These heating loads were used as the input for the variable alr volume heating system shown in Figure 5.

3. Geothermal water use, for the range of ambient temperatures ( $0 \mathrm{~F}$ to $65 \mathrm{~F}$ ), was estimated for system operation with three sizes of 
air/water heat exchangers. The heat exchanger sizes were 2ROW, 4ROW, and 6ROW.

4. The weather data was used to determine the average number of minutes during a heating season that the average dally temperature was between $0 \mathrm{~F}$ and $5 \mathrm{~F}, 5 \mathrm{~F}$ and $10 \mathrm{~F}$, and so forth up to $60 \mathrm{~F}$ and $65 \mathrm{~F}$.

5. Annual geothermal water use for the heating system operation with each heat exchanger was determined from the information obtained in the first four steps (Table 2).

TABLE 1: Primary Features of Hypothetical Office Structure and Heating System

Total Floor Area $=100,000 \mathrm{sq}$. ft. Heating System:

Maximum air flow $=100,000 \mathrm{cfm}$

Minimum fresh alr $=15,000 \mathrm{cfm}$

DesIgn heating load (C O F) 2,000,000 BTU/HR

Heat Exhanger Design (to be based on manufacturers' guidelines)

Air/Water - Finned Tube, Crossflow (2, 4, or 6 row, $34 \mathrm{ft}^{2}$ face area )

Water/Water - Plate Type, Counterflow

Maximum Al Flow $=31,500 \mathrm{cfm}$

Geothermal Supply Temperature $=165 \mathrm{~F}$

Loop Water Specifications

Supply Temperature $=160 \mathrm{~F}$ at $0 \mathrm{~F}$ amblent

Return Temperature $=130 \mathrm{~F}$ at $0 \mathrm{~F}$ amblent

Flow Rate - Based on design of alr/water heat exchanger 


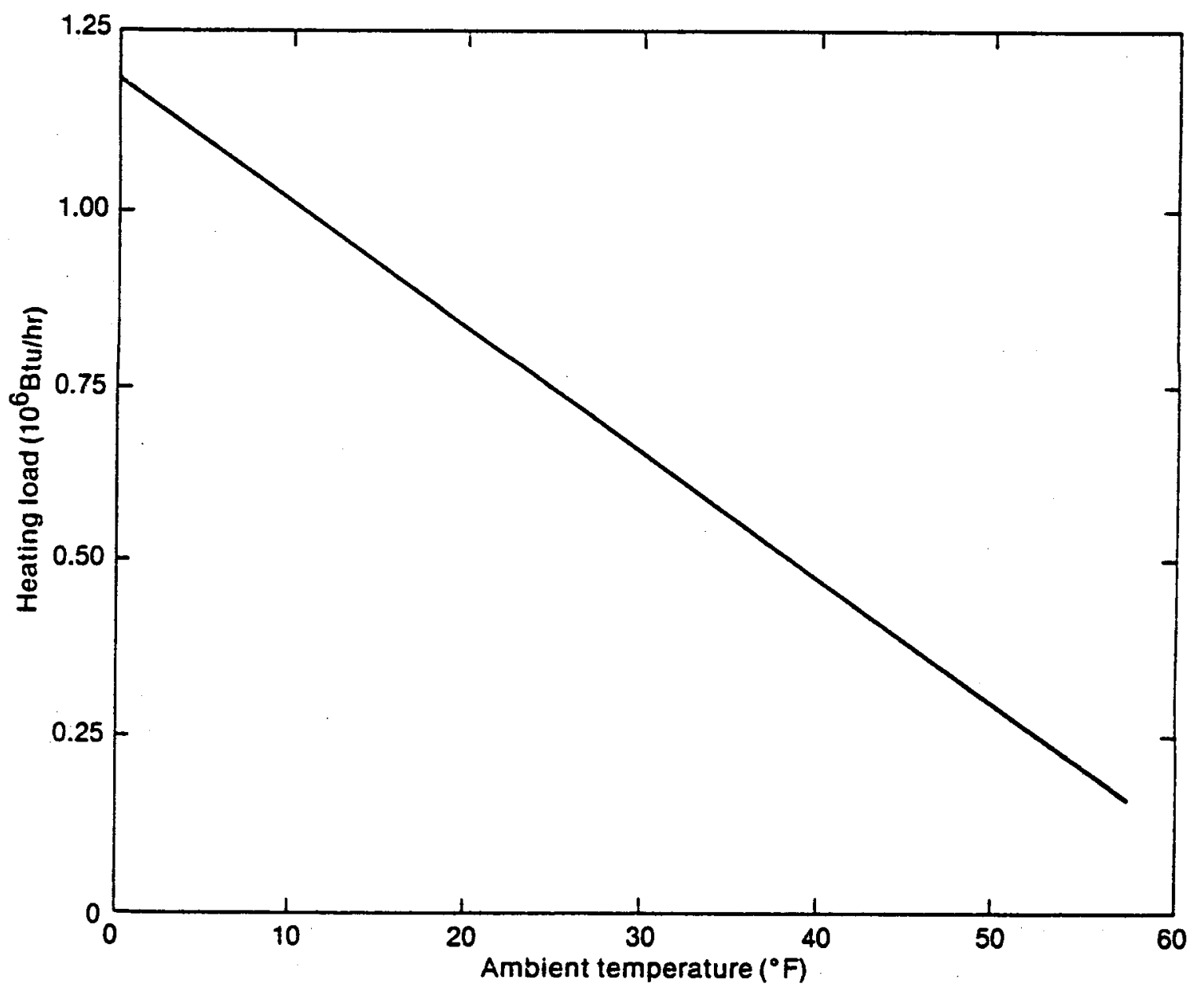

FIGURE 18. Heating Loss for Hypothetical Office Building at Various Ambient Temperatures 
It might be suggested that this procedure would provide Incorrect results for several different reasons:

1. Any glven heating season will have average dally temperatures that are significantly different from the mean of several heating seasons.

2. Transient phenomena in the heating load determination cause the actual heating load to lag amblent temperature changes. Therefore, the heating load predicted by a steady state model does not equal the actual heating load at a glven amblent temperature.

3. Average dally temperatures are a linear mean of the daily temperature and, as we have seen, geothermal water use is nonllnear with heating load.

Seasonal fluctuations are large, but averages must st111 be used for examining long term economics. The primary questions are: 1) Does the average daily temperatures provlde a reasonable estimate of the average dally heating load; and 2) can the geothermal water use predicted from this heating load be used to represent the Integrated use for that day? In order to answer these questions a simple comparison was made. The average dally temperature swings for several ranges of amblent temperature were complled along with the average dally temperature (Table 3). A sine function was then used to estimate the hourly temperatures for a glven average day and the geothermal water use was determined for these hourly temperatures. The results were totaled for each amblent temperature range and the number of minutes per year. The detalled calculations predicted an annual geothermal water use that was only 17 higher than that predicted by the average dally temperatures. Since this number is substantially lower than other sources of error, the average dally temperatures were used for the remaining calculations. 
TABLE 2. Example of Detalled Geothermal Water Use Calculation

\begin{tabular}{cc} 
Time & Ambient Temperature \\
of Day & $($ F $)$ \\
\hline $1: 00$ & -1.2 \\
$2: 00$ & -2.3 \\
$3: 00$ & -2.6 \\
$4: 00$ & -2.3 \\
$5: 00$ & -1.2 \\
$6: 00$ & 0.4 \\
$7: 00$ & 2.5 \\
$8: 00$ & 4.9 \\
$9: 00$ & 7.5 \\
$10: 00$ & 10.1 \\
$11: 00$ & 12.6 \\
$12: 00$ & 14.6 \\
$13: 00$ & 16.2 \\
$14: 00$ & 17.3 \\
$15: 00$ & 17.6 \\
$16: 00$ & 17.3 \\
$17: 00$ & 16.2 \\
$18: 00$ & 14.6 \\
$19: 00$ & 12.6 \\
$20: 00$ & 10.1 \\
$21: 00$ & 7.5 \\
$22: 00$ & 4.9 \\
$23: 00$ & 2.5 \\
$24: 00$ & 0.4
\end{tabular}

Geothermal Water Use

\begin{tabular}{rc} 
(gpm) & (Gal, hourly) \\
\hline 188 & 11,280 \\
200 & 12,000 \\
200 & 12,000 \\
200 & 12,000 \\
188 & 11,280 \\
170 & 10,200 \\
150 & 9,000 \\
130 & 7,800 \\
114 & 6,840 \\
102 & 6,120 \\
92 & 5,520 \\
85 & 5,100 \\
80 & 4,800 \\
75 & 4,500 \\
75 & 4,500 \\
75 & 4,500 \\
80 & 4,800 \\
85 & 5,100 \\
92 & 5,520 \\
102 & 6,120 \\
114 & 6,840 \\
130 & 7,800 \\
150 & 9,000 \\
170 & 10,200
\end{tabular}

Total Daily Use $=182,820$ Gallons Average Daily Use $=127 \mathrm{gpm}$ Average dally use based on $7.5 \mathrm{~F}$ ambient temperature $=113.5 \mathrm{gpm}$

TABLE 3. Summary of Detalled Geothermal Water Use Calculations

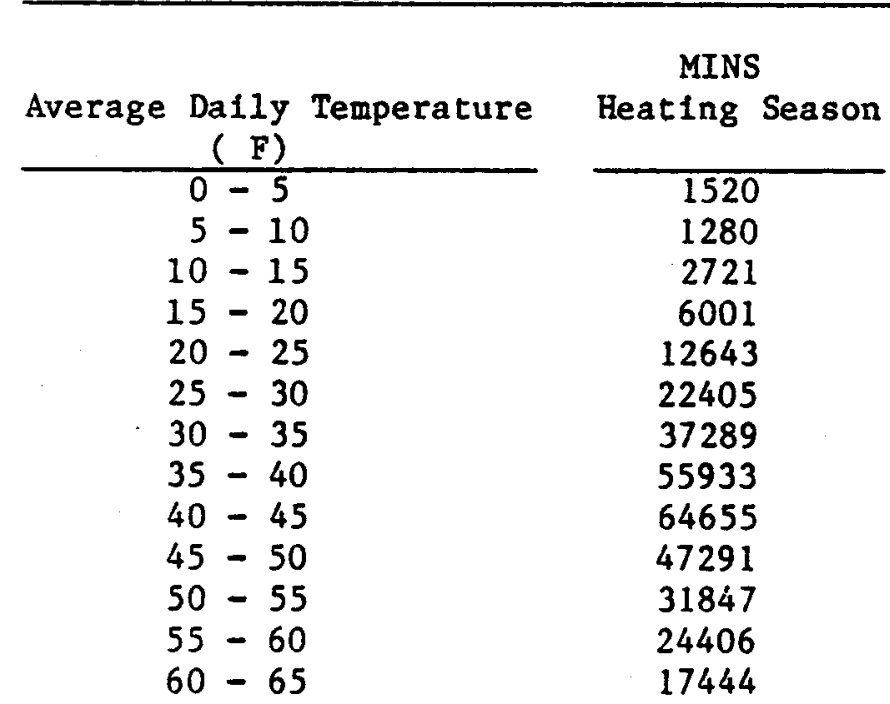

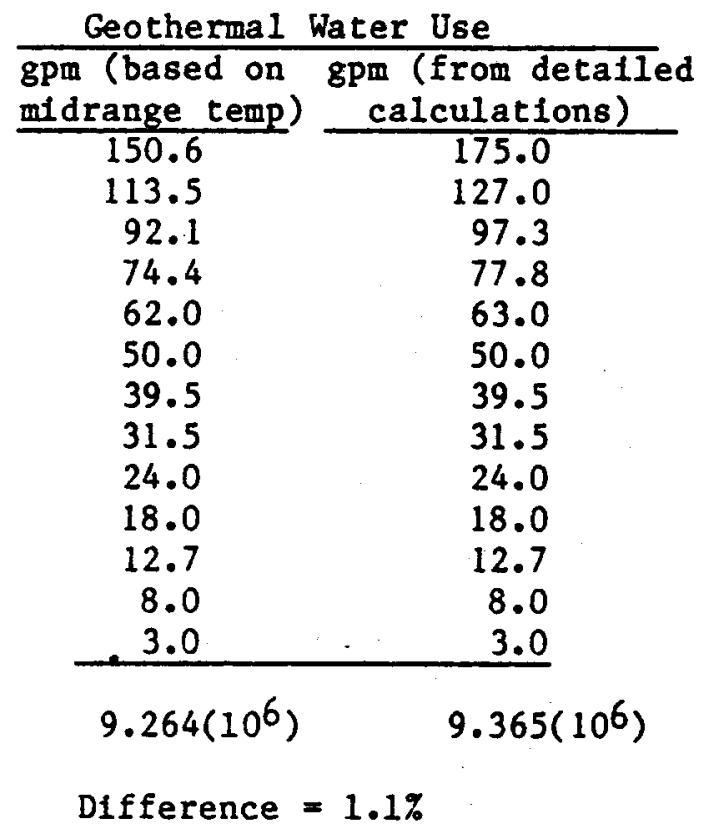


The annual geothermal water use for 2, 4, and 6 row alr-water heating colls was estimated using average daily temperatures for an average Boise, Idaho heating season. The total estimated geothermal water required was 9.26, 8.30 , and 7.96 million gallons for 2,4 , and 6 row heat exchangers respectively. Table 4 shows both the flow required and the annual use required for each temperature range.

The annual savings in geothermal water must then be compared to the increased cost of purchasing the successively larger heat exchangers. The results of this economic comparison are summarized in Table 5. A base price of $\$ 8500$ was used for the 2-row heat exchanger, with prices for larger sizes estimated using a 0.8 cost exponent. That is, for a 4 row exchanger, essentially twice the size or work required to produce, the estimated cost would be:

$$
\text { Cost }(4 \text { row })=\$ 8500(2)^{0.8}=\$ 14,799
$$

and for the 6-row

$$
\operatorname{Cost}(6 \text { row })=8500(3)^{0.8}=\$ 20,469
$$

So the incremental cost of purchasing a 4-row vs a 2-row is estimated as $\$ 6299$, and the 6-row vs 4-row as $\$ 5670$. These "incremental" cost numbers can then be compared to the incremental savings in geothermal energy cost. Shown on Table 5, then, are the incremental costs of purchasing additional heat exchanger capacity in confunction with the cost savings in geothermal water at three different typical costs for geothermal water. The incremental (first year) return on investment, ROI, Indicates that investment in the larger 4-row exchanger would be warranted, while the 6-row would $11 k e 1$ y not be a sound investment.

Recognizing that this conclusion would be Influenced by the local climate, the calculations were repeated for an assumed colder cllmate as described in Table 6, which also shows the estimated geothermal flow 
TABLE 4. Geothermal Flow Required Using Various Air-Water Heat Exchangers

\begin{tabular}{cc} 
Required Geo. & Geothermal Water \\
Water Flow Rate & Used (gal $\times 10^{-6}$ ) \\
\hline
\end{tabular}

\begin{tabular}{|c|c|c|c|c|c|c|c|c|}
\hline $\begin{array}{l}\text { Temp } \\
\text { Range } \\
(\mathrm{F}) \\
\end{array}$ & $\begin{array}{l}\text { Mean } \\
\text { Temp } \\
(\mathbf{F}) \\
\end{array}$ & $\begin{array}{l}\text { No. of minutes } \\
\text { Heating Season }\end{array}$ & 2-Row & 4-Row & 6-Row & 2-Row & 4-Row & 6-Ron \\
\hline $\begin{array}{c}0-5 \\
5-10 \\
10-15 \\
15-20 \\
20-25 \\
25-30 \\
30-35 \\
35-40 \\
40-45 \\
45-50 \\
50-55 \\
55-60 \\
60-65\end{array}$ & $\begin{array}{r}2.5 \\
7.5 \\
12.5 \\
17.5 \\
22.5 \\
27.5 \\
32.5 \\
37.5 \\
42.5 \\
47.5 \\
52.5 \\
57.5 \\
62.5\end{array}$ & $\begin{array}{r}1520 \\
1280 \\
2721 \\
6001 \\
12643 \\
22405 \\
37289 \\
55933 \\
64655 \\
47291 \\
31847 \\
24406 \\
17444 \\
\end{array}$ & $\begin{array}{r}150.6 \\
113.5 \\
92.1 \\
74.4 \\
62.0 \\
50.0 \\
39.5 \\
31.5 \\
24.0 \\
18.0 \\
12.7 \\
8.0 \\
3.0 \\
\end{array}$ & $\begin{array}{r}107.4 \\
86.6 \\
73.2 \\
61.2 \\
51.0 \\
43.0 \\
35.0 \\
28.7 \\
23.0 \\
17.5 \\
12.0 \\
8.0 \\
3.0 \\
\end{array}$ & $\begin{array}{r}98.4 \\
80.5 \\
68.7 \\
58.0 \\
49.0 \\
41.0 \\
34.0 \\
27.5 \\
21.5 \\
17.0 \\
12.0 \\
8.0 \\
3.0 \\
\end{array}$ & $\begin{array}{l}0.229 \\
0.145 \\
0.251 \\
0.446 \\
0.784 \\
1.120 \\
1.473 \\
1.762 \\
1.552 \\
0.851 \\
0.404 \\
0.195 \\
0.052\end{array}$ & $\begin{array}{l}0.163 \\
0.111 \\
0.199 \\
0.367 \\
0.645 \\
0.963 \\
1.305 \\
1.605 \\
1.487 \\
0.828 \\
0.382 \\
0.195 \\
0.052 \\
\end{array}$ & $\begin{array}{l}0.150 \\
0.103 \\
0.187 \\
0.348 \\
0.620 \\
0.919 \\
1.268 \\
1.538 \\
1.390 \\
0.804 \\
0.382 \\
0.195 \\
0.052\end{array}$ \\
\hline \multicolumn{2}{|c|}{$\begin{array}{l}\text { TOTAL FOR } \\
\text { HEATING SEASON }\end{array}$} & 325435 & & & & 9.264 & 8.302 & 7.956 \\
\hline
\end{tabular}


TABLE 5. Incremental Cost Savings for Increased Heat Exchanger Capacity

\begin{tabular}{|c|c|c|c|c|c|}
\hline $\begin{array}{c}\text { Heat } \\
\text { Exchanger } \\
\text { Comparison }\end{array}$ & $\begin{array}{l}\text { Incremental } \\
\text { Inves tment } \\
(\$) \\
\end{array}$ & $\begin{array}{c}\text { Cost of } \\
\text { Geo. Water } \\
(\$ / 100 \mathrm{ft})\end{array}$ & $\begin{array}{c}\text { Geothermal } \\
\text { Savings } \\
(\mathrm{gal} / \mathrm{yr})\end{array}$ & $(s / y r)$ & $\begin{array}{c}\text { Incremental } \\
\text { ROI } \\
(\%) \\
\end{array}$ \\
\hline $\begin{array}{l}2 \text { Row/4Row } \\
4 \text { Row/6Row }\end{array}$ & $\begin{array}{l}6299 \\
5670\end{array}$ & $\begin{array}{l}0.50 \\
0.75 \\
1.00 \\
0.50 \\
0.75 \\
1.00\end{array}$ & $\begin{array}{l}0.962\left(10^{6}\right) \\
0.346\left(10^{6}\right)\end{array}$ & $\begin{array}{r}643 \\
965 \\
1286 \\
231 \\
347 \\
462\end{array}$ & $\begin{array}{r}10.2 \\
15.3 \\
20.4 \\
4.1 \\
6.1 \\
8.1\end{array}$ \\
\hline
\end{tabular}

TABLE 6. Geothermal Water Required for Colder Climate for Varlous Alr-Water Heat Exchangers

Annual Geothermal Water Used (Ga1 $\times 10^{-6}$ )

Mean

\begin{tabular}{|c|c|c|c|c|}
\hline $\begin{array}{l}\text { Temperature } \\
(F)\end{array}$ & $\begin{array}{l}\text { Heating Season } \\
\text { (min) }\end{array}$ & 2-Row & 4-Row & 6-Row \\
\hline \multirow[t]{2}{*}{$\begin{array}{r}2.5 \\
7.5 \\
12.5 \\
17.5 \\
22.5 \\
27.5 \\
32.5 \\
37.5 \\
42.5 \\
47.5 \\
52.5 \\
57.5 \\
62.5\end{array}$} & $\begin{array}{r}2721 \\
6001 \\
12643 \\
22405 \\
37289 \\
55933 \\
64655 \\
47291 \\
31847 \\
24406 \\
17444 \\
1520 \\
1280\end{array}$ & $\begin{array}{l}0.410 \\
0.681 \\
1.164 \\
1.667 \\
2.312 \\
2.797 \\
2.554 \\
1.490 \\
0.764 \\
0.439 \\
0.222 \\
0.012 \\
0.004\end{array}$ & $\begin{array}{l}0.292 \\
0.520 \\
0.925 \\
1.371 \\
1.902 \\
2.405 \\
2.263 \\
1.357 \\
0.732 \\
0.427 \\
0.209 \\
0.012 \\
0.004 \\
\end{array}$ & $\begin{array}{l}0.268 \\
0.483 \\
0.869 \\
1.299 \\
1.827 \\
2.293 \\
2.198 \\
1.301 \\
0.685 \\
0.415 \\
0.209 \\
0.012 \\
0.004\end{array}$ \\
\hline & & 14.516 & 12.419 & 11.863 \\
\hline
\end{tabular}


required for 2, 4 and 6 row heat exchangers. The incremental cost savings for this climate are shown on Table 7, along with the incremental purchase price of the additional capacity and the first year return on investment. In this case, the 4-row is the obvious choice over the two row, while incremental ROI's up to $10-15 \%$ are now reallzable for the 6-row vs the 4-row.

TABLE 7. Incremental Cost Savings for Increased Heat Exchanger Capacity - Colder Climate

\begin{tabular}{|c|c|c|c|c|c|}
\hline \multirow{2}{*}{$\begin{array}{c}\text { Heat } \\
\text { Exchanger } \\
\text { Comparison } \\
\end{array}$} & \multirow{2}{*}{$\begin{array}{l}\text { Incremental } \\
\text { Investment } \\
(s) \\
\end{array}$} & \multirow{2}{*}{$\begin{array}{l}\text { Cost of } \\
\text { Geo. Water } \\
(\$ / 100 \mathrm{ft})\end{array}$} & \multicolumn{2}{|c|}{$\begin{array}{l}\text { Geo. Water } \\
\text { Savings }\end{array}$} & \multirow{2}{*}{$\begin{array}{c}\begin{array}{c}\text { Incremental } \\
\text { ROI }\end{array} \\
(\%) \\
\end{array}$} \\
\hline & & & $(\mathrm{gal} / \mathrm{yr})$ & $(s / y r)$ & \\
\hline 4 Row $/ 6$ Row & 5670 & $\begin{array}{l}0.50 \\
0.75 \\
1.00 \\
0.50 \\
0.75 \\
1.00 \\
\end{array}$ & $0.5560\left(10^{6}\right)$ & $\begin{array}{r}1402 \\
2103 \\
2803 \\
371 \\
557 \\
743 \\
\end{array}$ & $\begin{array}{r}22.3 \\
33.4 \\
44.5 \\
6.5 \\
9.8 \\
13.1 \\
\end{array}$ \\
\hline
\end{tabular}

An important distinction must be made in calculating investment return between overall return versus incremental return. The overall return for the entire project might still appear favorable for installing even larger capacities, but the Incremental savings vs incremental cost would not warrent the larger heat exchangers. In performing these economic design calculations, it is necessary that the overall as well as the incremental return on Inveṣtment be estimated.

There is an additional economic consideration that is suggested by the required geothermal flow as illustrated on Table 4 (or Table 6). Note that, as expected, the geothermal flow goes up dramatically as the amblent temperature decreases, but that the total annual water demand to supply energy during the time that the temperature is at the lower range is not a major part of the 
total use. The Implication is that, for the climate spectfied (Boise, Idaho), where only $14 \%$ of the total demand occurs at a temperature lower than $30 \mathrm{~F}$, it may be undesirable to design geothermal heating systems to supply the full demand down to, say $0 \mathrm{~F}$. Th1s factor is strongly coupled to the fact that, for high demand, geothermal use rises almost exponentlally as the demand increases. (Higher approach temperatures are required in the geothermal heat exchangers as the demand goes up, resulting in significantly increased flow. In the limit, as the loop water supply temperature approaches the geothermal source temperature, the geothermal flow must theoretically tend toward Infinfty.) An economic analysis of appropriate design loads for geothermal heating systems is the subject of the following section, which was presented at the October 1983 meeting of the Geothermal Resources Counc1l, In Portland, Oregon (11).

There are economic trade-offs between the capital expenditures versus the savings realized as a function of the design temperature. Also, for a given geothermal resource, an Increased number of users can be satiofled if higher design temperatures are specifled. These considerations become even more Important for retrofit applications, where a back-up conventional heating system is already in place.

\subsection{SYSTEM ECONOMIC ANALYSIS}

This section, entitled "Economic Advantages in Using Conventional Energy Supplements in the Design of Geothermal District Heating Systems," was presented at the 1983 Annual Meeting of the Geothermal Resources Council. This paper discusses the impact of usage factor on district heating economles and means of improving these economics by optimizing the number of buildings in the district heating system. 
ECONOMICAL ADVANTAGES. IN USING CONVENTIONAL ENERGY SUPPLEMENTS IN THE OESIGN OF GEOTHERHAL DISTRICT HEATING SYSTENS

\author{
James A. Batdorf and George M. Simons
}

Department of Chemical Engineering University of Idano

\section{ABSTRACT}

Most geothermal heating systems are designed to handle the maximum losd anticipated during a normal heating season. Typically, this load is associated with an ambient temperature of near $0^{\circ} \mathrm{F}$. Since geothermal water usage increases exponentially as the load demand increases, designing to handle such a high peak load results in a very low usage factor (less than 20\%) for the heating season. This means that less than 20\% of the energy that could be supplied by a geothermal source is actualiy used. Designing for peak loads to occur at higher temperatures (eg. $20^{\circ} \mathrm{F}$ ) and using natural gas as a supplenent below that temperature, results in signifcant increases in geothermal utilization and overall natural gas savings. The economic tradeoffs in aetermining the optimum design temperature are discussed.

\section{BACKGROUND}

Many geothermal energy resources in the Hestern United States are low temperature (less than $200^{\circ} \mathrm{F}$ ) hot water reserves. This quality of resource is best utilized in low temperature direct use applications such as space heating. Given the high cost of exploration and resource development it is more economical to develop resources that have a relatively large application. Since individual space heating demands are relatively small, it is usually necessary to develop a system for multiple users. These nultiple user, or District Heating Systems are receiving considerable interest throughout the Western United States ( 1 ).

The retrofit of an existing space heating system for use with a geothermal water energy source generally utilizes the following strategy. A primary heat exchanger transfers energy from the geothemal water to a secondary working fluid (generally water). This fluid is then circulated to the building(s) to heat the room air. The primary heat exchanger may be located at or near the geothermal water production well or it may be located within the building. These differences are generally determined by such factors as the corrosion and precipitation properties of the particular geothemal flutd. After energy transfer from the secondary fluid to the building air the secondary fluid is recirculated back to the prlmary heat exchanger. Geothermal fluid leaving the primary heat exchanger is either surface discharged or reinjected into the substrata.

Depending on the particular design and installation of the existing heating system the extent of modifications required to convert to geothermal heating can vary over a wide range. from connecting into an existing hot water loop to modifying the air-handling equipment to accept larger heat exchangers and higher pressure drops. In most applications the original system is retained to provide emergency back-up and peak load requirements.

Changing the design point at which the back-up system is to.be activated alters the geothermal system usage factor (ratio of actual use to system capacity). The system economics are primarily dependent on fixed costs and therefore the unit cost of geothermal energy is approximately equal to the annual fixed costs divided by the annual geotherma) energy usage (usage factor times system capacity). This indicates that the geothermal energy unit cost is inversely related to the usage factor. In order to improve the economics of geothermal systems, it is generally desirable to increase the geothermal usage factor. Normally there is no control over the usage factor, however if the original system design includes back-up capability, this usage factor can be increased by relying more on backup energy and expanding the system stze to include more buildings. Obviously there is a trade-off between decreasing the cost of the geothermal energy and using more supplenental energy, which in turn requires additional capital for retrofitting additjonal buildings. This paoer examines the economics of this trade-off and suggests that a switch over to back-up systems be done at ambient temperatures considerably higher than is normally done.

\section{DISTRICT HEATING}

A geothermal district heating system can be operated in a number of ways. A private investment group or municipal utility may develop the resource, construct the transmission system and 
sell the geothermal fluid. In other cases the developer and the consumer may be one in the same. For Instance. In the Capttol Mall Heating Project In Bofse. Idaho, the State of Idaho developed the resource and the energy will be used to heat state owned bulldings (2).

The design of a geothermal district heating system requires careful planning and economic evaluation. Most of the system parameters are fixed by the resource location. the amount of production expected. the expected demand and the demand location. The areas available for greatest economic improvement are retrofte design and matching of the resource and denand. Several methods of improving the design and operation of a retrofitted heating system have been previously documented $(3,4,5)$. In order to match the retrofit to the demand the number of buildings to be supplied should be adjusted along with the peak design load to be provided by the geothermal resource.

\section{DISTRICT HEATING ECONOMICS}

There are many ways to analyze the economics of a geothermal district heating system. In all cases the project economics are complicated by the variations in development and retrofit costs and by governmental incentives (tax credits, exploration and development grants, demonstration project grants, etc.). A good example of a recently completed district heating project is the Capitol Mall Geothermal Energy Project in Boise. Idaho. Over $95 \%$ of the $\$ 1,850,000$ oroject cost was funded by the State of Idaho. The expected annual savings in natural gas expenditures is $\$ 150,000$ (based on 1981 natural gas costs) (2). This would amount to a $7 \%$ return on the capital investment over a 30 year period. This simple analysis is based solely on the amortization of the capital investment and does not account for changes in operating costs, inflation, or escalation of natural gas costs.

Bloomster, et.al. (6) has published a comprehensive report on the costs associated with the development and operation of a geothermal district heating system. They discuss the sensitivity of the delivered energy cost to many factors including financing, well cost. usage factor, resource temperature and flow rate, well life. transmission and distribution costs, and geothermal flutd disposal costs. The energy cost is also dependent on the cost required to modify an existing heating system. This report indicates that the economics of a geothermal district heating system are determined primarily by the initial capital inves tment cost, the type of financing, and the usage factor. The variable costs (operation, maintenance, and pumping) are reported to be small when compared to the annual fixed costs (6). In order to more accurately determine and further improve the economics of a geothermal heating system it is necessary to determine the usage factor under different operating conditions.

\section{USAGE FACTOR DETERMINATICH}

Usage factors can be calculated by Integrating the geothermal flow requirements for a typical heating system over a typlcal heating season. This requires an accurate estimate of the heating requirements and the assoctated geothermal fluid flow requirements. Also it is necessary to know the distribution of heating requi rements during a typical heating season. Figure I shows distribution of average dafly temperatures for the heating season in Boise. Idaho (these were compiled from 20 years of weather data). Various methods are available to estimate the heating requirements for a buflding with specifled size, contruction, and ventilation requirements $(7,8,9)$. Figure 2 shows the results of this type of analysis for a typical $100,000 \mathrm{sq}$. ft. office structure. Computer modeling techniques have also been developed to calculate the geothermal water requirements for a speciffe geothermal heating system $(4,5)$. Figure 3 shows the results of this type of andiysis for the office structure of Figyre 2 and the geothermal heating system shown in Figure 4. Combining this information allows the prediction of the annual geothermal water requirements for given bullding operating with a specific heating system under typical weather conditfons. The annual amount of geothermal water required by the above mentioned office structure for a typical Boise. Idaho heating season would be $9,264,000$ gail ons. This estimate is based on a minimum design temperature of $0^{\circ} \mathrm{F}$, at which the peak geothermal flow is 175 gpm. For system designed spectfically to meet this building's energy needs (peak flow of $175 \mathrm{gpm}$ ) the total system capacity would be $56,950,000$ gallons for the total heating season. thus the usage factor would be 0.163 . The usage factor for a district heating system of similarly designed buildings would be lower if the total system peak capacity was greater than the sum of the building peak requirements.

\section{OPTIMIZATION OF OISTRICT MEATING SYSTEM ECONOMICS}

The following analysis is for a hypotheticai system of buildings, each haring geothermal usage requirements similar to those shown in figure 3. Assuming that this system has a maximum geothermal supply of $1000 \mathrm{gpm}$ the annual usage factor can be calculated for various design temperatures. This design temperature is the point below which the back-up system is utflized to supplement heating requirements beyond the geothermal resource capabilities. As this temperature is increased more butldings can be added to the system since. the peak demand for each building is then lower. Figure 5 shows the results of this analysis. Note that the usage factor starts at 0.163 which corresponds to 5.7 butidings on the system $(1000$ $\mathrm{gpm} / 175 \mathrm{gpm}$ peak load) and approaches 1.0 at temperature of $68^{\circ} \mathrm{F}$ (1000 butidings using $1 \mathrm{gpm}$ throughout the heating season).

For given geothermal supply, the addition of another building to the systen affects the 
economics in a number of ways. First, there is an increase in capital expense to retrofit the butlding and extend the distribution system to tre bullding. Second, the pesk amount of geothermal fluld avallable to each individual user is reduced. The third effect is an tncrease in. the total amount of geothermal flutd supplied by the system for a given heating season. Fourth, the amount of supplemental energy required by each Individual user will be increased as their peak geothermal capacity is reduced. The optimum number of bulldings to place on a geothemal district heating system will depend primarily on the above economic impacts as well as the capabilities of the back-up systen.

After a geothermal district heating project has been developed and is operational. it is obviously important to attempt to operate the system in such a manner as to maximize the economic return. The fixed costs involved in operating a district heating system include amitorization of the capital expenses for the resource exploration and development, distribution systen construction, and heating system modification. The variable costs include supplemental energy costs, pumping costs, and operation and maintenance costs. The addition of a building to the geothermal heating system does not greatly affect the operation and maintenance costs and the pumping costs are at least an order of magnitude below the other costs. This indicates that the important costs to consider are the capital amortization costs and the supplemental energy costs. The "income" from a district heating system is the reduction in supplemental fuel expenaltures. inerefore, ile lins imum. economic return is a trade-off between increased savings in supplemental fuel expenses and increased expenses for distribution system expansion and heating system modifications.

The geothermal energy unit cost is calculated using life cycle costing and discounted cash flow analyses similar to that described by Bloomster. et. ai. (6):

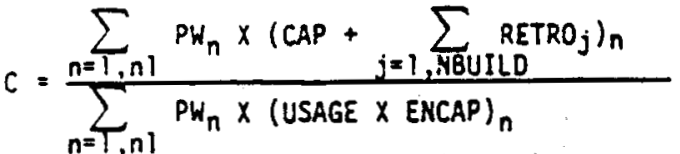

$$
\begin{aligned}
& C=\text { unit cost of geothermal energy } \\
& \text { nl = useful life, years } \\
& P W=\text { present worth factor } \\
& \text { CAP } \times \text { Capital cost of well and transmission system } \\
& \text { RETRO = capital cost for each building } \\
& \text { NBUILD = number of buildings on the system } \\
& \text { USAGE = annual usage factor } \\
& \text { ENCAP = energy capacity of the system }
\end{aligned}
$$

A cost analysis based on a municipal financed system with $8 \%$ financing and a 30 year project iffe was used to determine the effect of the usage factor on the geothermal unit energy cost. The basis for the cost analysis included an initial investment cost of $\$ 1,000,000$, a cost of $\$ 100,000$ for the addition of each building to the system, and a system energy capicity based on $1000 \mathrm{gpm}$ and $50{ }^{\circ} \mathrm{F}$ temperature drop. The relation between the usage factor, number of buildings, and design temperature was determined as described for Figure $S_{1}$ and resulted in the cost estinates as shown in Flgure 6 . Note that the minimum cost occurs at a design temperature of $40^{\circ} \mathrm{F}$, this roughly corresponds to the location of the maxi. mum in the average dally temperature distribution shown in Figure i.

As economic analysis was also performed for a user owned system. In this case the incremental return from adding buildings to the system was estimated. As before, it is assumed that the geothermai resource has a maximum flow of 1000 $\mathrm{gpm}$. The cost of adding a building to the system was estimated at $\$ 100,000$. Natural gas savings were determined for operating the system with various design temperatures. these savings. were based on a natural gas cost of $\$ 0.50 / 700,000$ BTU. The results showed that increasing the number of hypothetical buildings heated by geother$\mathrm{mal}$ energy from 5.7 to 7.7 resulted in an incremental ROI of 10.7\%; this corresponds to changing the design temperature (for peak load geothermal heating) from $0^{\circ} \mathrm{F}$ to $5^{\circ} \mathrm{F}$. As this design temperature increased, the incremental ROI slowly decreased. Changing the design temperature from $25^{\circ} \mathrm{F}$ to $30^{\circ} \mathrm{F}(17.9$ hypothetical buildings to 20) resulted in an incremental ROI of 9.2\%. These results do not include any consideration for the escalation of natural gas costs or the variations in retrofit costs. As stated previously, the retrofit costs can vary greatly depending on the present building heating system ( $\$ 100,000$ was felt to represent an upper limit on these costs for the described butlding). The impact of natural gas cost escalation can also be significant. For this system, at $0^{\circ} \mathrm{F}$ design temperature, 142,000 therms of natural gas were displaced by the geothermal energy. At a design temperature of $30^{\circ} \mathrm{F}, 476,000$ thenms of natural gas were displaced by the geothermal energy ( 5.7 versus 20 buildings).

\section{CONCLUSIONS}

Large capital expenditures are requireo to develop a geothermal district heating project. Energy consumption for pumping and supplemental energy requirements for heating are the primary variable costs. Since the annual fixed costs for capital recovery are much larger than the variable costs, the geothermal energy cost is heavily dependent on the system usage factor. The design of a geothermal neating system should therefore include an accurate usage factor evaluation. This can only be accomplished by analyzing the combined effects of the heating season temoerature distribution and the geothermal heating system performance. Future work by the authors will characterize varicus heating system/weather combinations with respect to usage factors.

The following considerations apply to the design of a geothermal district heating system where the users will own and operate the system. For heating systems with back-up or supplemental heating capabilities the unit cost of the geothermal energy can be minimized by correct selection of the system usage factor. This 
requires the addition of a suffictent number of bulldings to the system so that the geothermal flow 1 s at its maximum value when the amblent temperature drops to a predetermined level, below which the extra energy required is supplied by the back-up system. Our intitial studies indicate that this point roughily colncides with the peak in the seasonal distribution of average daily temperatures, eg. $40^{\circ} \mathrm{F}$ for colse, Idaho. Optimum economics for the heating system should also include an examination of the incremental return for the addition of each new bullding, these returns vary over a wide range depending on the specific retrofit costs for each bullding.

Utility owned systems will also benefit from increasing the usage factor. The system usage factor is determined by the end user and is therefore not directly controllable by the energy supplier. However, since the cost of supplying the geothermal energy is a direct function of the usage factor it may be advantageous for the supplier to attempt indirect control by providing cost incentives and/or penal ties relating to individual use. More direct control might be achieved by usage agreements that limit the maximum flow to an individual user. This will also benefit the consumers, as higher usage factors will result in lower geothemal energy. costs and therefore an improved return on consumer retrofit investment costs. This also provides utilities with an incentive to help consumers conserve geothermal energy by correct equipment selection and proper operation.

This work has been conducted under contract from the Department of Energy. Idaho Operattons Office, Idaho Falls, Idaho.

\section{REFERENCES}

1 Fornes, Ann 0., 1981, "Direct-Use Geothermal Oistrict Heating Projects in the U.S... A Sumary," Geothermal Energy, 10(4), p 198

2 State of Idaho, Dept. of Administration, Public Works, 1983, "The Capitol Mall Geothemal Energy Project"

3 Hul1, Glen; Simmons, George; May 1975. "A Retrofitted Geothermal Heating System," ASHRAE Journal, $21(5)$, p 45.

4 Simons, George M.; Ali, Syed 1.; Batdorf, James A.; Oct. 1980. "Modeling and Control of Geothermal Heating Srstems," ISA Transactiuns, Vol. 20, No. $1,1981$.

5 Batdorf, James A., April 1982, "Modeling of Geothermal-Water Space Heating Systems to Improve System Operation and Control," Master of Sctence Thesis. University of Idaho Graduate School.

6 Bloomster, C.H.; Fassbinder, L.L.; McDonald, C.L.: 1977, "Geothermal Energy Potential for District and Process Heating Applications in the U.S.An Economic Analysis," Geothermal Energy Recent Developments (ed. M.J. Collie), Moyes Data Corporation, 1978
7 MBSLD. Computer Program for Heating and Cooling Loads in Bulldings," 1974. "BSIR 14-574. National Bureau of Standards

8 Freeman. Thomas, Sept. 1976. "TRNSYS, A Transient Simulation Program," Report 38 , Untverstey of Wisconsin Solar Energy Laboratory. Madison Wisconsin

9 "81bitography on Avallable Computer Programs in the General Area of Heating, Refrigerating. Air Conditfonting, and Ventllating," 1975. American Soctety of. Heating, Refrigerating. and Air Conditioning Engineers, Inc. 
Batdorf

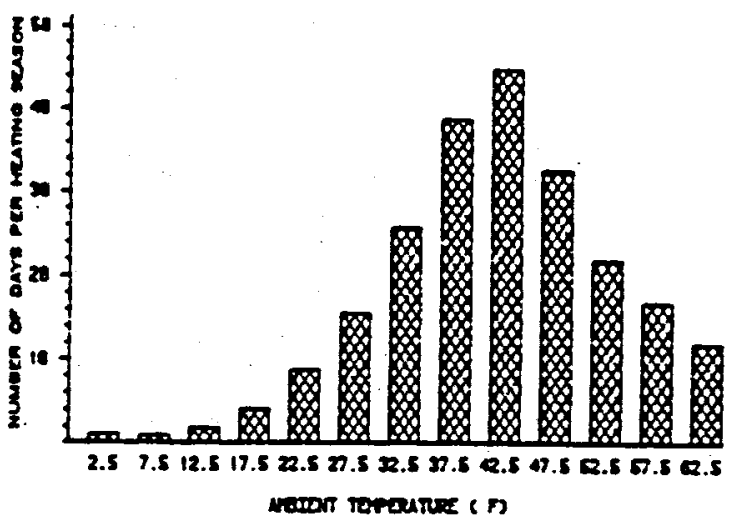

FIGURE I: DISTRIBUTION OF AVERAGE DALYY TEMPERATURE

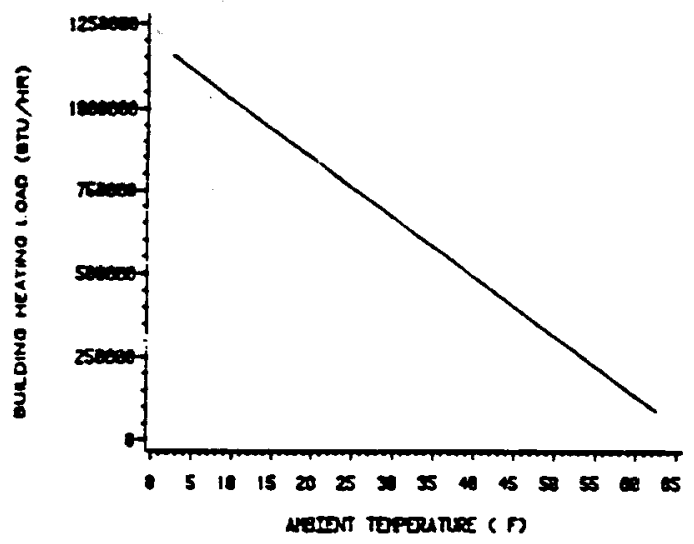

FIGURE 2: BUILDING HEATING LOAD VS. AMBIENT TEMPERATURE

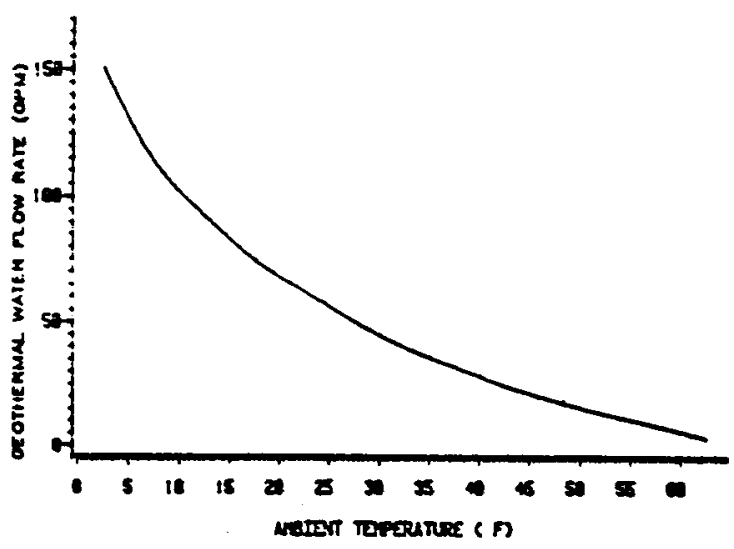

FGURE 3: GEOTHERUAL FLOW RATE VS. MMIENT TEMPERUTURE

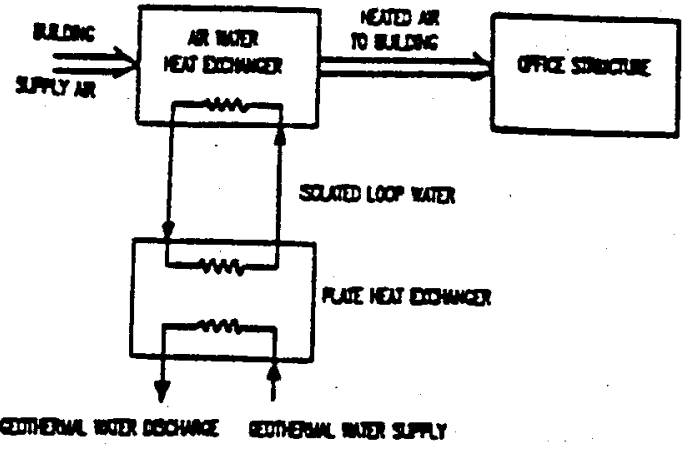

FGURE 4: GEOTHERUAL HEATNG RETROFT CONFIGURATION FOR A TPICAL OFFICE STRUCTURE

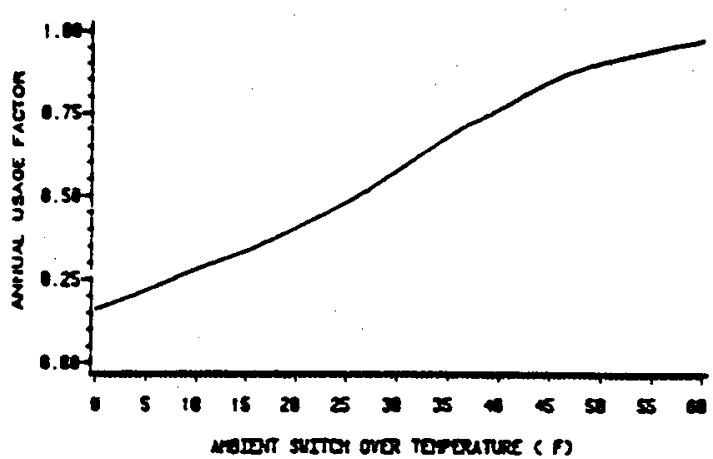

FIGURE 5: ANNUAL USAGE FACTOR VS. ALBIENT DESIGN TEMPERATURE

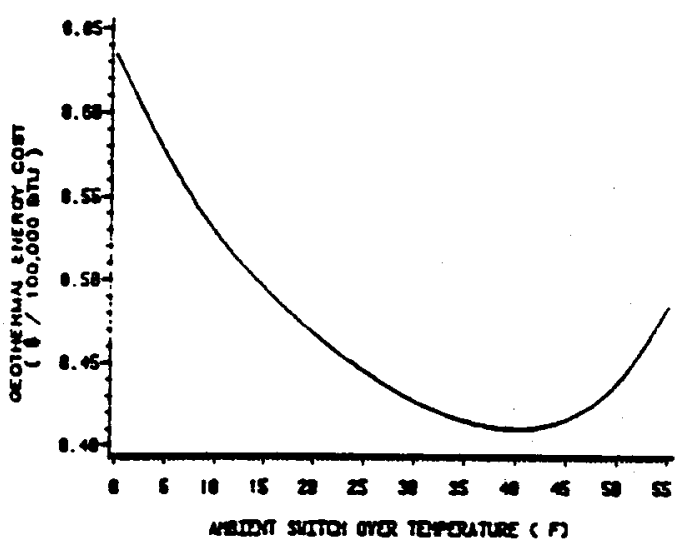

FIGURE 6: GEOTHERUAL UNT ENERGY COST VS. AMGIENT DESIGN TEMPERATURE 


\subsection{SUMMARY OF RECOMENDATIONS}

By examination of several standard heating systems for operation on geothermal energy, there are varlous general guidelines that become evident for decreasing the utilization for geothermal water.

\subsection{LOOP WATER FLOW}

As was seen in Section 2, the loop water flow as recommended by heat exchanger manufacturers is generally about $50 \%$ of what it should be for efficlent utilization of geothermal water. First, it should be pointed out that the manufacturers are not making a mistake, but are providing guidelines for conventional energy supplies or heating systems. They are balancing the energy extracted against pumping cost. For a conventionally fired boiler, which in turn heats the loop water for a bullding's heating system, it makes Iittle difference what the loop water flow rate is, since the energy that does not get extracted in the alr-water heat exchanger 18 returned, and thereby recovered, in the boller. For geothermal systems, however, the energy must be extracted in one pass, as there is no recovery possibility (with the exception of cascaded systems). As the loop water flow is decreased, the temperature at which the loop water must be supplled must necessarily increase to deliver the required energy. As this temperature increases, eventually approaching the source temperature of the geothermal water, the geothermal flow must Increase dramatically. Once again, with a natural gas flame source temperature in a conventionally fired boller, there is no problem in increasing the loop water temperature, as $1 t$ would never approach the gas temperature.

Let us examine what happens as the design value for the loop water flow continues to increase. If the temperature of the loop water were to remain constant while supplying the same energy demand, then as the flow rate goes up, the return temperature back to the geothermal primary heater must rise 
accordingly. This return temperature is the lower limit for geothermal water rejection from the primary heat exchanger. It is most important to note, therefore, that as the loop water flow rate is increased, the supply temperature must be decreased accordingly to achieve the results shown in Section 2.

It appears that a flow rate approximately twice normal design recommendations is appropriate, with an accompanying drop in the temperature of the loop water supply.

The overall guldeline in setting loop water supply temperature is to maximize the efflciency of the alr-water heat exchanger. This is done by dropping the supply temperature until an afr flow rate through the air-water heat exchanger is near maximum. As the loop water supply temperature is decreased, then the return temperature is also decreased, allowing for maximum utilization of the geothermal water.

\subsection{DESIGN TEMPERATURE}

Typical design temperatures for a large portion of the United States are in the range of about $O F$. Let us examine the consequences of using a design temperature this low for a geothermally heated system. As discussed in Section 3.2 , only about 10 to 15 percent of the total annual heating demand occurs at amblent temperatures below about $30 \mathrm{~F}$. For a given geothermal well, with a limited geothermal flow, requiring that the system supply all energy requirements down to $O F$ severely limits the usage factor for the geothermal supply. Coupled with the fact that the efficlency of geothermal systems goes down as the demand goes up (once again due to the close approach temperature to the geothermal source temperature), it might be suggested that design temperatures closer to about $30 \mathrm{~F}$ should be considered. The extra energy that must be supplied to operate the heating system at lower ambient temperatures 
would then be supplied by conventional (gas, oll, electriclty) high temperature sources. The use of a higher design temperature for the geothermal system allows additional users to be served, hence the larger usage factor for a given geothermal source.

There are admittedly several other economic considerations in selecting an appropriate design temperature, such as the avallability of a back-up system and geographical closeness of end users. The suggestion 1s that a higher design temperature at least be consldered for geothermal systems, with the final answer based on sound economics rather than adherence to conventional designs for conventional systems.

\subsection{MAXIMIZING HEAT EXCHANGER EFFICIENCY}

As stated prevlously under the discussion of loop water flow and temperature, the goal is to drop the loop water temperature until the alr-water heat exchanger(s) are operating near maximum alr flow, which achleves the highest heat transfer coefflcient. The point at which this occurs depends entirely upon the required heating load that the system must supply. There are two ways to track the load and make the control changes on loop water supply temperature: 1) ambient reset control, and 2) zone comparator reset.

Use of an amblent reset control is a simple and cost effective way to monttor the bullding's heating load. As the amblent temperature drops, the loop water supply temperature must increase, and a linear reset schedule as implemented by this commerclally avallable device is quite an approprlate way to Implement control. In all cases examined by Rolfson (12), however, the zone comparator does an even better job and tracks actual energy demand much better. The zone comparator takes into account the variance in the energy demand from zone to zone, allowing for a non-uniform distribution of people 
(energy provided by body heat) and lighting, and for other energy sinks and sources. The ambient reset controller must by deslgn be a compromise, and in the effort to guarantee that the bullding will always have sufficlent heat under all conditions, the tendency is to use a reset schedule that is always safe. The best designed schedule is very close to the operation of the zone comparator, however, the building operator will almost always move the set points higher than is necessary. Th1s phenomonon 18 "un-controlled" and is a real problem. For this reason alone, it appears that the use of the zone comparator is warranted. The cost of installation for the comparator is somewhat higher, but the estimated payout times for the increased expense over the amblent reset controller are on the order of one to two years.

\subsection{HEAT EXCHANGER DESIGN}

Here again, because of the non-recoverable nature of geothermal energy, it appears that heat exchangers on the order of twice the capacity normally recommended are economicaliy attractive. In section 3.1 , the incremental return on investment for the Incorporation of larger air-water heat exchangers indicates that the use of a 4-row heat exchanger over a 2-row is certainly Indicated, and the use even a 6-row may be warranted in colder climates.

There is a natural process in system design that may turn a relatively Inefficlent design into a good one. First, it appears that the manufacturers guidelines are somewhat conservative, in that they have the responsibility to guarantee a given performance. Also, In borderline cases, the design engineer always will select the next larger size. The net result is that the heat exchanger may be somewhat "overdesigned" for conventional systems, but quite appropriate for geothermally operated systems. The remaining problem when these safety margins are built in is that the capability of the heating system is underestimated, and therefore underut1lized. The net result is that more 
geothermal water is spent than necessary.

The best approach is for the design engineer to know what the heat exchanger performance actually is, and to design the control system with minimal safety margin. Use of zone comparison generally satisfies any requirement for bullt-in safety margin.

\subsection{THREE-WAY MIXING VALVES}

If three-way mixing valves are incorporated into the heating system, then the best way to operate the system is to continue to lower the temperature unt1l the valves are nearly or totally off. They are a convenient and effective way to control system operation, but may result in more energy spent than necessary. For conventional systems, they are quite appropriate, but not so for geothermal systems. The reason why the use of such devices causes more geothermal water to be utilized is that they are in a fact a bypass around the heat exchanger. This bypass results in higher return temperatures to the primary geothermal heat exchanger thereby limiting the temperature to which the geothermal water can be refected.

\subsection{CONTROLLING GEOTHERMAL FLOW}

The basic question of why the geothermal flow should be regulated at all should be addressed. If the geothermal source is significantly larger than the demand, then there probably is little reason to limit the geothermal flow. However, as flow increases, the life of the geothermal well is limited, and peaking the flow beyond that necessary most certainly degrades the well performance. Further, proper design allows for more users to be served and for higher usage factors. As geothermal systems become more common, then the demand for the resource will increase so that erficient utilization will be even more required to keep the cost of dellvered energy down. 


\subsection{ADDITIONAL CONTROL STRATEGIES}

In addition to the design and control suggestions developed in this document, there are specific guidelines that we have published previously $(13,14)$ that might be considered by the design engineer.

1) Night set back. This strategy sets the bullding temperature down for overnight operation, thus decreasing the energy loss from the bullding. In many cases examined, however, this approach results in a greater demand for geothermal water, in that the system must peak in morning hours, with a decreased operational efficlency. For buildings with a high throughput of outside air (such as chemical or biological laboratorles), the use of night set back would be energy efficient, but not so for office bufldings whereby most of the air is recycled. The use of this control strategy should not be automatically implemented, but should be examined on a case by case basis.

2) Fresh Air Heat Exchangers. For a building that has a high percentage of recycle air, the minimum return temperature for the loop water is the building temperature, usually $68 \mathrm{~F}$. On cold days, where the fresh or make-up air is considerably less than $68 \mathrm{~F}$, the incorporation of a fresh air heat exchanger saves a significant anount of geothermal energy and is a cost effective addition to the heating system. After the 10op water has passed through the primary alr-water heat exchanger, it then passes through a fresh air heat exchanger which directly contacts the outside air before it is mixed with the recycle air. The standard argument against this procedure is the fear of freezing the heat exchanger, so that 40 to $45 \mathrm{deg} F$. protection 11 mits on the alr exiting the heat exchanger are sometimes implemented. In such cases, however, the loop water temperature still remains far above $40 \mathrm{~F}$, so that the temperature $11 \mathrm{mit}$ is unnecessarłly high. An alternate strategy is to monitor the temperature in 
the loop water and provide an alarm or automatic drain when the loop water temperature approaches $40 \mathrm{~F}$.

3) Interior zone temperatures. The central part of a large bullding requires cooling throughout the year, as there is no way to dissipate heat to the exterior zones that are maintained at $68 \mathrm{~F}$. (The top floor of the center section would loose heat through the celling, however.) In order to maintain the central zone at $68 \mathrm{~F}$, a significant amount of cool, fresh alr must be admitted to the building, which must then be heated to $68 \mathrm{~F}$. About 5\% of the heating expediture can be saved if the temperature can be allowed to float upward.

\subsection{PERSONNEL QUALIFICATIONS}

As heating systems become more complicated, and as the heating cost becomes a larger part of the operating cost, attention should be given to the selection and training of the staff responsible for the day to day operation of the physical plant. Once a well designed system is installed and made operational, the job is not over. Commonly held bellefs concerning proper operation are often incorrect, and on-site adjustments by building staff often negate the excellent englneering that has been completed. Complete computer controlled systems are now belng installed that in some cases remove control from the operator. For the short term, this approach can work, but as the system degrades and needs maintenance and updating, the on-site personnel will be asked to assume responsibility.

\subsection{ENERGY ACCOUNTABILITY}

Incentive for reducing the energy required for space heating is of ten lacking in government operated facilities. Budgetary constraints sometimes negate any Individual reward or compensation for a job well done. Money saved 
on energy consumption is not generally avallable to the facility to use on other projects or needs, and may go back to a general fund. The net result 1s often an unconcerned attitude toward energy fonservation.

\subsection{GEMS PROGRAM METHODS}

The modeling for this project was accomplished with the use of two computer programs. A transient simulation program TRNSYS (5) was used to estimate bullding heating loads. This information was then used as input to a second program GEMS, General Energy and Material Balance Simulation, University of Idaho $(6,15,16)$. The GEMS program is based on a modular concept where each equipment item is assembled from a serles of modules that describe the processes occurring within that equipment. For example, the central heating unit shown in Figure $19 a$ would be assembled with varlous modules as shown In Figure 19b. As with any programming there are certain "tricks" that reduce operator frustration and increase productivity. In the course of using GEMS to model several types of heating systems, we have discovered several means of simplifying the program or reducing the run time without altering the results. The following paragraphs 1dentify these "tips" and programming guidelines. The spectfic programing modules for the alr water heat exchanger, AkHX, and the plate heat exchanger, are described in Append1x A.

\subsection{FRESH AIR CONTROL}

For a typical system, the amount of fresh air 18 adjusted to maintain a temperature in the cold deck. The exhaust air 18 modulated to maintain a pressure balance. The required GEMS modules and controls are shown in Figure 20. The GPMOD block passes the flow of the fresh alr stream to the SPLIT block, which is executed after GCTRL has adjusted the fresh alr flow. Both GPMOD and GCTRL are again executed after the SPLIT and MIXER blocks 


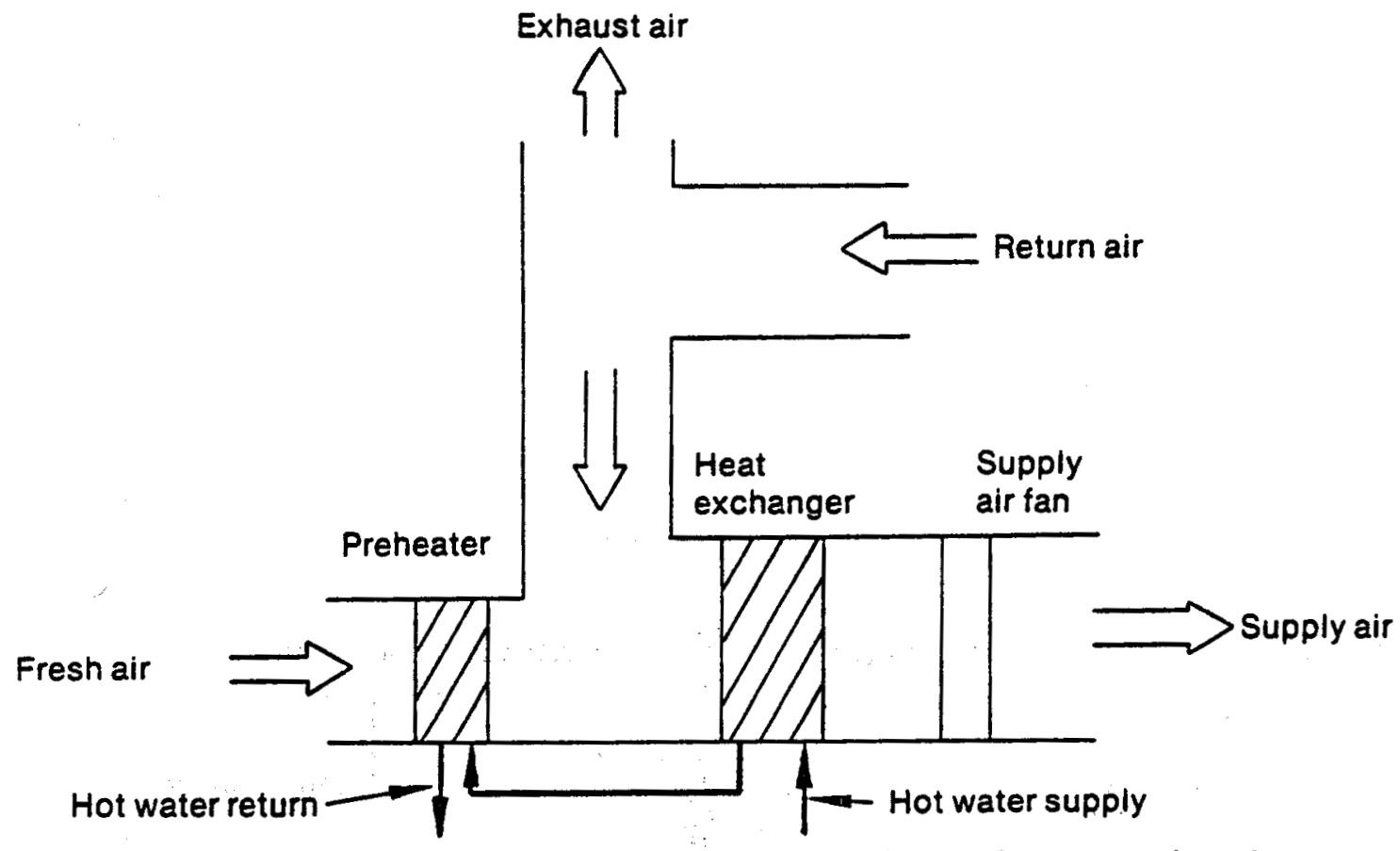

FIGURE 19a. Conventional Single Zone Fixed Air Volume Heating System

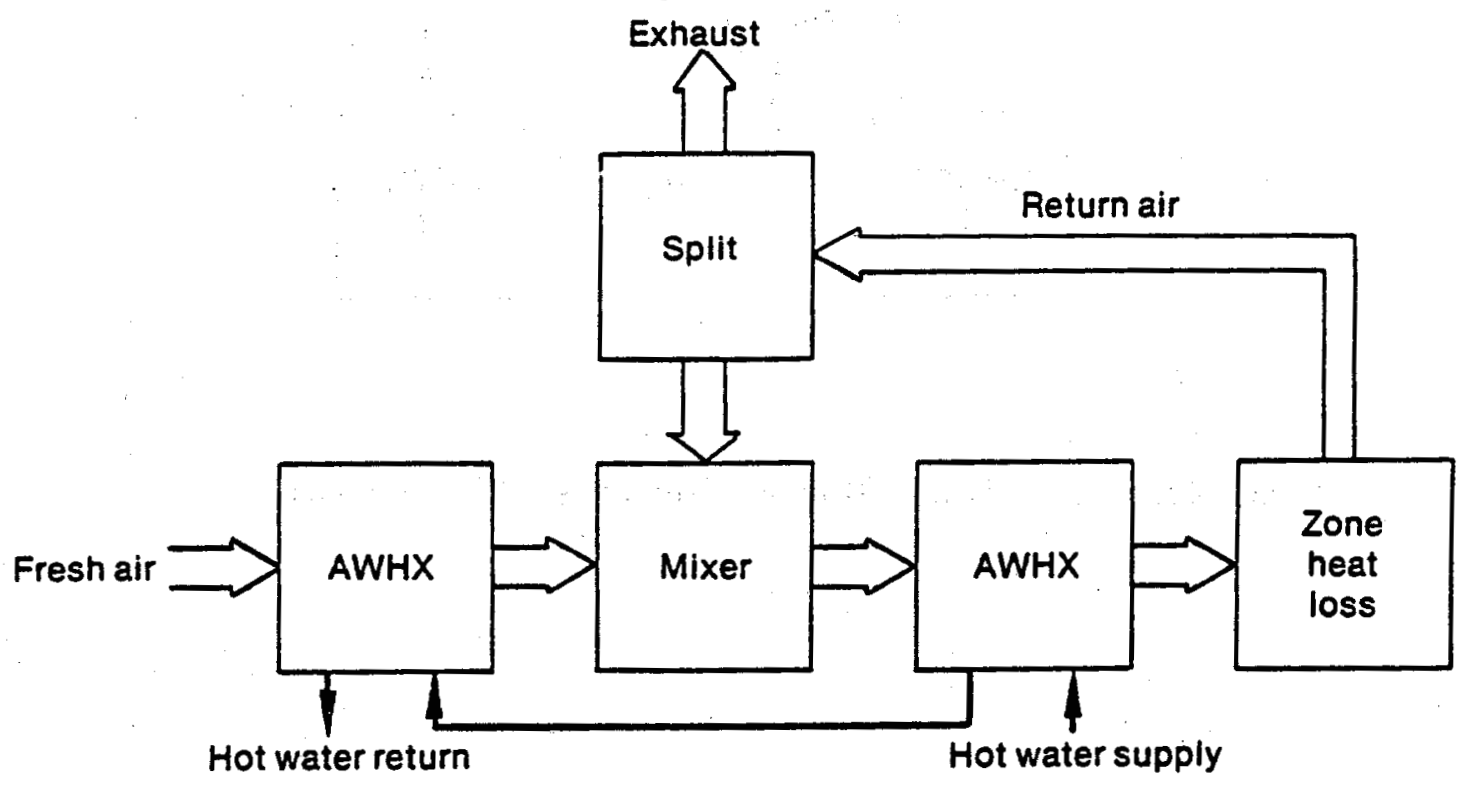

FIGURE 19b. GEMS Block Diagram for Heating System ( $A$ WHX = Air water heat exchanger) 


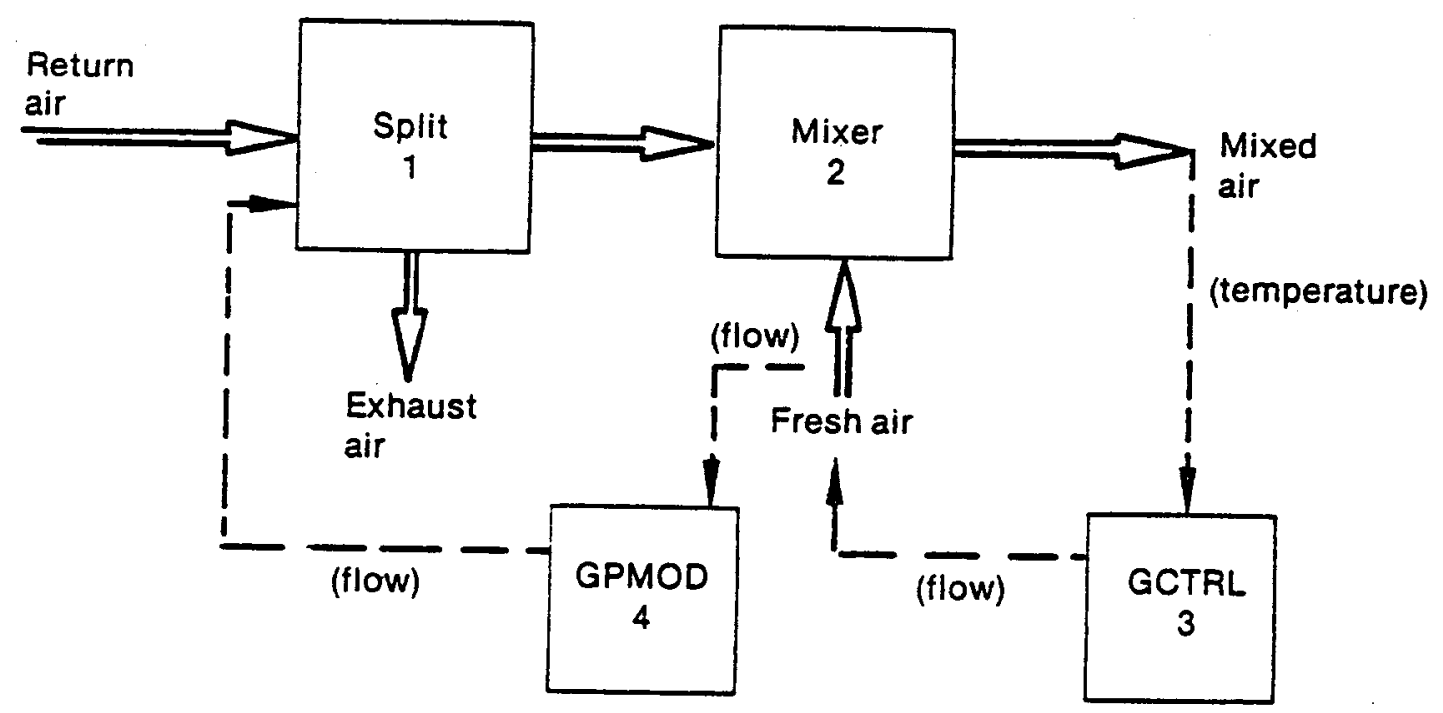

FIGURE 20. GEMS Block Diagram for Fresh Air Control 
maintalning the alr balance (mass alr in = mass alr out).

\subsection{ELIMINATING RECYCLE LOOPS}

Nested recycle loops, especially when each level is controlled, are very slow in reaching convergence. Figure 21 shows the GEMS block diagram for a constant volume, dual duct heating system. This is the system used to perform the economic analysis in Section 3. There are varlous controllers in this system; one controller maintains the cold duct temperature by modulating the exhaust and fresh alr flows, and a second controller malntains the hot duct temperature by adjusting water flow rate. Other controllers malntain each zone temperature by regulating the flow of hot and cold alr to the zone. As the zone controllers are regulated the percentage of the air flow between hot and cold ducts varles (total flow remains constant). In the course of reaching a converged solution this can cause many problems (zero flows, split block errors, etc.) and the materlal balance can cause convergence difficulties.

Many of these problems can be ellminated by disconnecting the return alr 10op. A flxed flow of alr is then supplied to the first SPLIT block at the converged temperature (69 F in most cases). Convergence is then achleved when the return alr stream after zone heat 1088 in Figure 21 has the same flow and temperature as the return air stream to the split block. In this way, the entire system always has the correct total flow to start with.

\subsection{DETERMINING CONTROLLER GAINS}

F1gure 22 shows the GEMS block diagram for a varlable alr volume system with terminal reheat units. In this system the return air temperature is known (destred zone cemperature), but the quantity of air is unknown. Convergence of this system is best achleved by the following steps: 


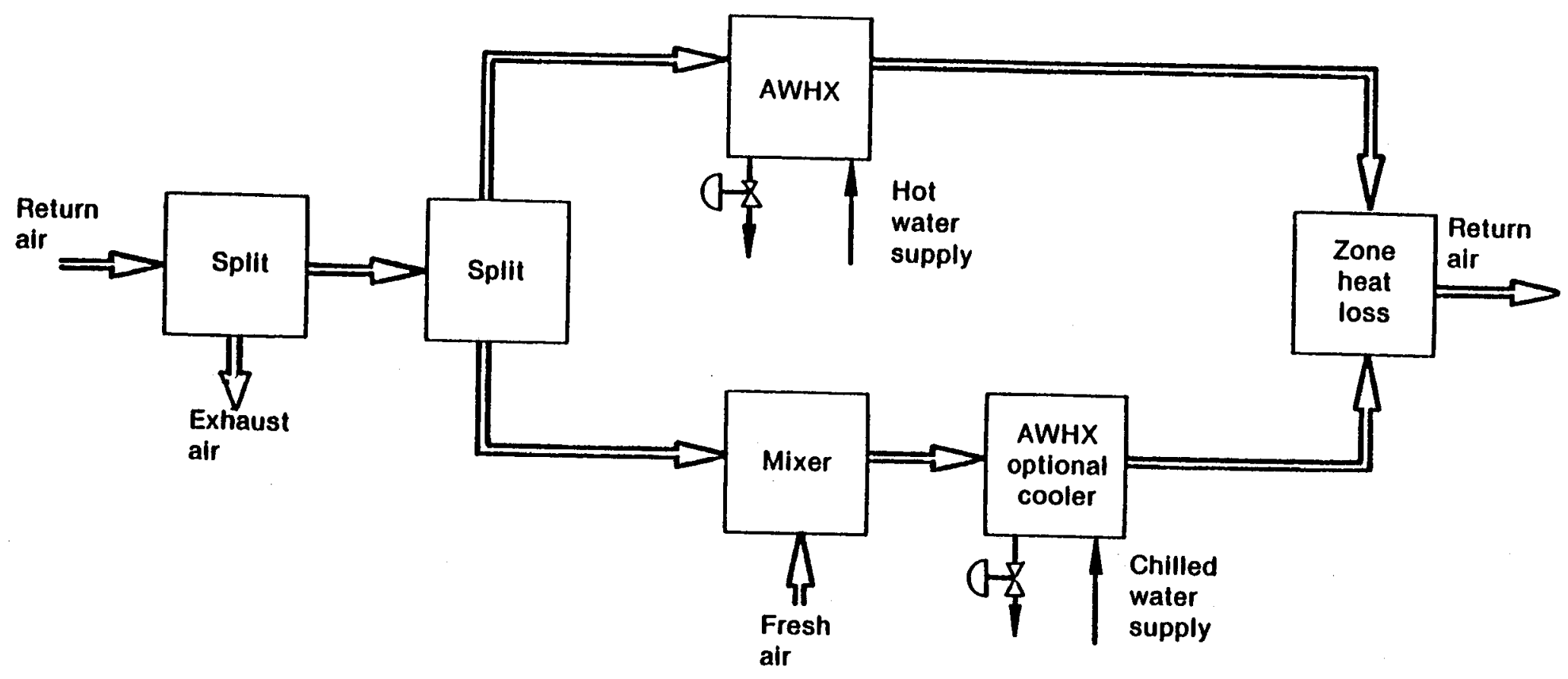

FIGURE 21. Simplified GEMS Block Diagram for Dual Duct Constant Volume Heating System 


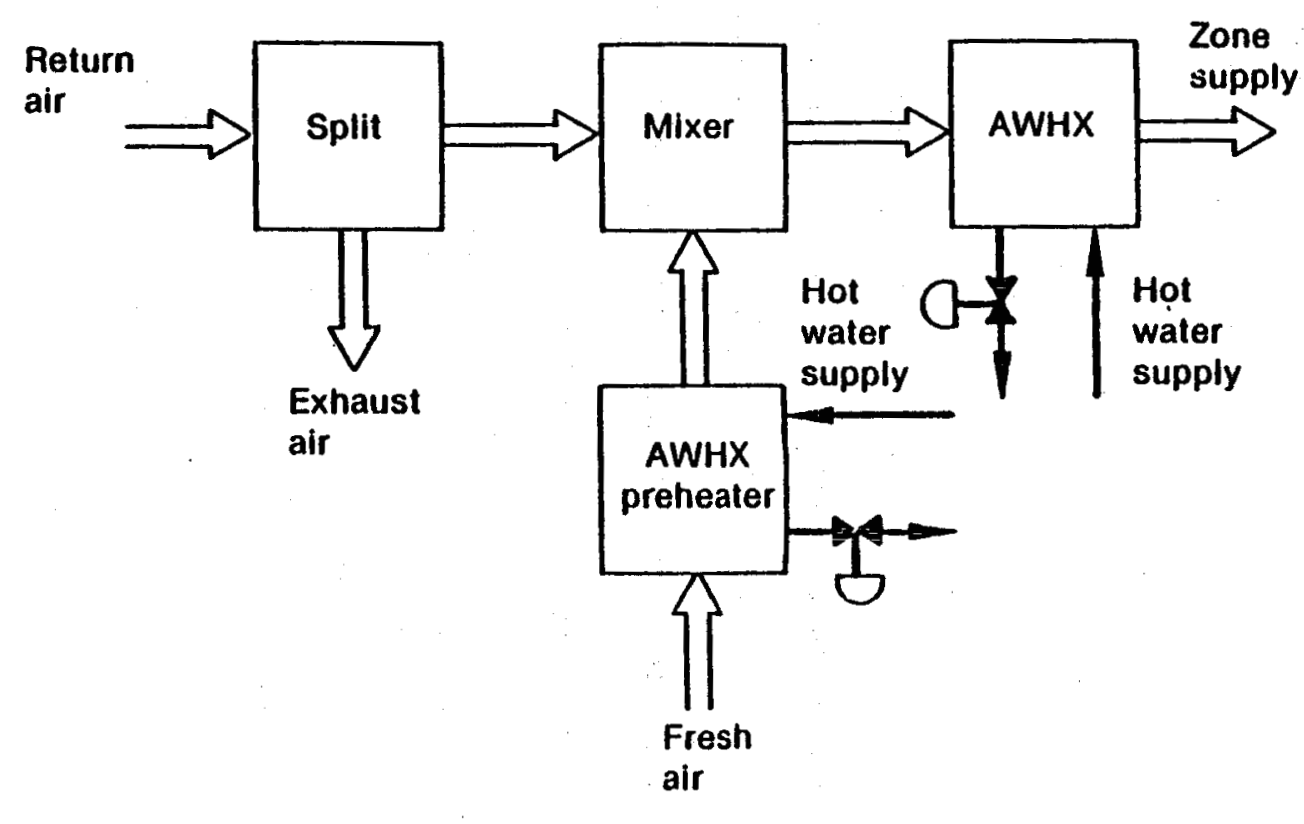

Central air handling

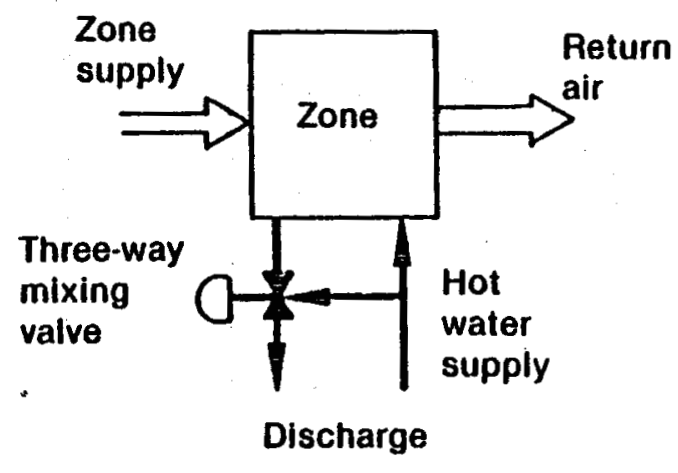

Zone air handling

FIGURE 22. GEMS Block Diagram for Single Duct VAV with Terminal Reheat 
1. Break return atr loop

2. Fix return air temperature

3. Use a GCTRL block to control the flow or return alr to the simulation

4. Use apropriate controller gains

Approprlate controller gain can only be determined by trial and error but some general trends have been observed. The controllers on interior loops should be applied each iteration with a galn on the order of 1.0 . Controllers on exterior loops should not be applied until the interfor loops have stabilized, this can require as few as 2 or as many as 50 1terations. The gain on the exterior controller should also be on the order of 1.0 ; In most cases, the programming can start with a value of 0.6 and increase in increments of 0.2 as long as stability is achieved.

\subsection{COMBINING HEAT EXCHANGERS}

In many cases it is convenient to combine a number of zones and their respective heat exchangers to simplify the complexity of the simulation. Appendix B explains the detalls of modeling heat exchangers with the GEMS module AWHX and identifies the key concepts required to combine heat exchangers and maintain modeling accuracy. 


\section{APPENDIX A: GEMS Subroutines}

\section{A-1.0 Air-Water Heat Exchanger}

The air water heat exchanger used by Ali (17) was modified to provide complete compatability with other GEMS subroutines. The following documentation on the air-water heat exchanger written for GEMS is divided into seven sections. The first two sections describe the equations and calculational procedure used within the heat exchanger model. The third section discusses the selection of the equation used to determine the air side heat transfer coefficient, and the fourth section compares the output of the model to information published by two different manufacturers of finned heat exchangers.

\section{A-1.1 Calculational Procedure}

The following calculational procedure determines the outlet temperature of the air and water streams given the exchanger construction details and the air and water inlet conditions. The procedure is based on the work of Kays and London (18).

1. Input construction details of heat exchanger

- frontal height

- frontal width

- depth

- tube dianeter
- fin spacing

- fin thickness

- thermal conductivity of fin

2. Input temperature and flow of inlet water

3. Input temperature and flow of inlet air

4. Guess outlet stream temperatures

- outlet air tempetature = inlet air temperature

- outlet water temperature = inlet water temperature 
5. Calculate average stream temperatures

$-T($ avg $)=(T$ (inlet $)+T$ (outlet) $) / 2.0$

6. Calculate air and water properties as a function of their respective average stream temperatures

- density

- thermal conductivity

- heat capacity

- viscosity

7. Calculate the air mass flow rate

8. Calculate the minimum cross sectional air flow area

9. Calculate the air velocity based on the above area

10. Calculate the water velocity

11. Calculate heat transfer areas

12. Calculate dimensionless parameters

- Reynolds Number

- Prandt 1 Number

- Nusselt Number

- Capacity Rate Ratio

13. Calculate air and water heat transfer coefficients

14. Calculate fin efficiency

15. Calculate average overall heat transfer coefficient

16. Calculate NTU based on air side area and minimum capacity rate

17. Calculate exchanger effectiveness from Kays and London (18) correlation for cross-flow exchangers with both sides unmixed

18. Calculate total heat transfered

19. Calculate outlet temperatures

20. Compare outlet temperatures with previous guesses and return to step number 5 if convergence has not been reached 
A-1.2 Primary Equations

The following list of equations were used in the appropriate calculational steps identified in the previous section (see section A-1.5 for nomenclature).

1. Calculate Heat Transfer Coefficients

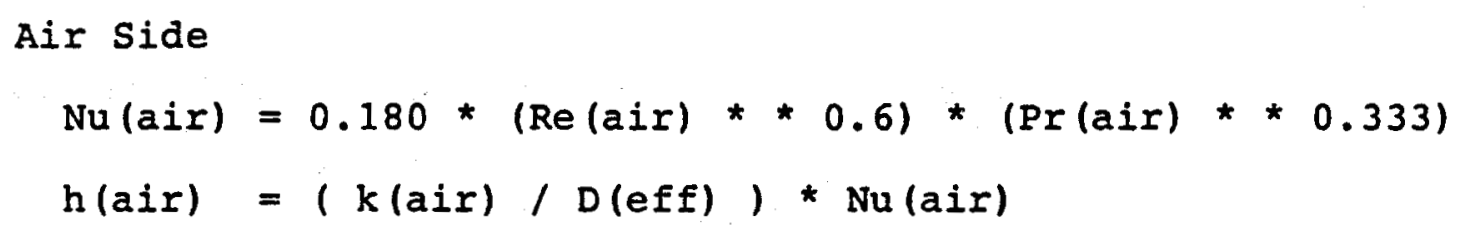

2. Calculate Efficiency of Fin Surface

$$
N(f)=\tanh (m * \operatorname{del}) /(m * \operatorname{del})
$$

$$
\begin{aligned}
& \text { where } m=\{(2 * h(a i r)) /(k(f i n) * x(f i n))\} * * 0.5 \\
& \operatorname{del}=[(\mathrm{FH}-\mathrm{NT} * \mathrm{D}(\text { tube })) /(2 * \mathrm{NT})]
\end{aligned}
$$


3. Calculate Fin Efficiency

$$
N(0)=1.0-[A(f i n) /(A(f i n)+A(t u b e))\} *\{1.0-N(f)\}
$$

4. Calculate Average Overall Heat Transfer Coefficient

$$
\frac{1.0}{U(\text { avg })}=\frac{1.0}{(N(0) * h(\text { air })}+\frac{A(f i n)}{(A(\text { tube }) * h(\text { water }))}+R(w)+F F
$$

5. Calculate NTU based on air side area and minimum capacity rate

$$
\mathrm{NTU}=(\mathrm{A}(\mathrm{fin}) * \mathrm{U}(\mathrm{avg})) / \mathrm{C}(\mathrm{min})
$$

6. Evaluate Exchanger Effectiveness from relationship for cross-flow heat exchangers with both sides unmixed

$$
\begin{aligned}
\mathrm{EA} & =\frac{1.0}{\mathrm{ZA} * \mathrm{NTU}} \sum_{\mathrm{n}=0}^{\infty}(\mathrm{TI} * \mathrm{~T} 2) \\
\text { where } \quad \mathrm{T} 1 & =1.0-\exp (-\mathrm{NTU}) \sum_{\mathrm{m}=0}^{\mathrm{n}}\{(\mathrm{NTU} * * \mathrm{~m}) / \mathrm{m} !\} \\
\mathrm{T} 2 & =1.0-\exp (-\mathrm{ZA} * \mathrm{NTU}) \sum_{\mathrm{m}=0}^{\mathrm{n}}[(\mathrm{ZA} * \mathrm{NTU}) * * \mathrm{~m} / \mathrm{m} !\}
\end{aligned}
$$

7. Calculate Total Heat Transfered

$$
Q=C(\min ) *(T(\text { hot in) }-T(\operatorname{cold} \text { in })) * E A
$$

8. Calculate Outlet Temperatures

$$
\begin{aligned}
& T \text { (hot out) }=T(\text { hot in) }-Q / C \text { (hot) } \\
& T(\text { cold out) }=T(\operatorname{cold} \text { in) }-Q / C(\operatorname{cold})
\end{aligned}
$$


A-1.3 Air side Heat Transfer Coefficient

The equations presented for air-side heat transfer coefficients are generally in the form of a modified Dittus-Boelter equation. For heat transfer in air flowing cross-flow to finned tubes the constants for the equation vary as shown below:

$$
\begin{aligned}
\text { Nu }(a i r)=a *(\operatorname{Re} * * b) *(P r * * c) \\
\text { where } a=0.10 \text { to } 0.20 \\
b=0.50 \text { to } 0.70 \\
c=0.30 \text { to } 0.40
\end{aligned}
$$

The Reynolds number is based on a length dimension of 4 times the hydraulic radius. Briggs and young (24) modified this by including terms for the fin height and thickness:

$$
\begin{aligned}
\mathrm{Nu}(\operatorname{air})= & 0.134 *(\operatorname{Re} * * 0.681) *(\mathrm{Pr} * * 0.333) \\
& *((\mathrm{~s} / 1) * * 0.2) *((\mathrm{~s} / \mathrm{t}) * * 0.113)
\end{aligned}
$$

The last two terms were examined for typical air conditioning heat exchanger configurations, the resulting product was found to range from 0.8 to 1.0 . This suggests that this correlation could be viewed as a Dittus-Boelter equation with the following parameters:

$$
\begin{gathered}
\text { Nu }(\text { air })=a *(\operatorname{Re} * * 0.681) *(\operatorname{Pr} * * 0.333) \\
\text { where } a=0.110 \text { to } 0.126
\end{gathered}
$$


Rich (20) modified the Dittus-Boelter equation to include terms for the tube spacing in the direction of air flow. This resulted in the folowing equation:

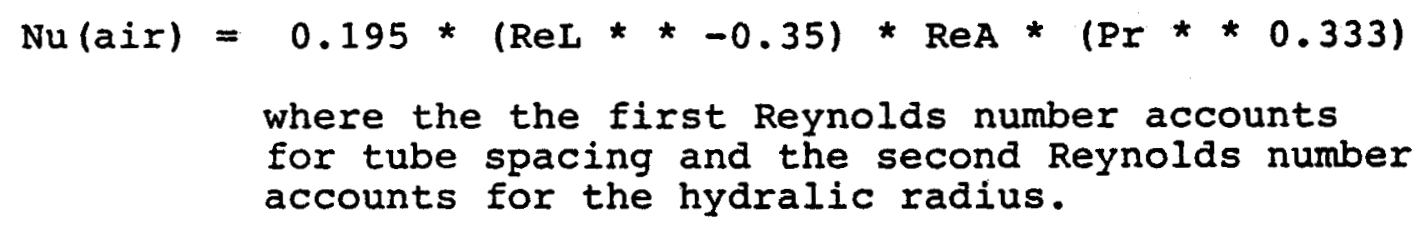

This correlation was also examined for typical conditions found in air conditioning heat exchangers, the results indicated that this could be expressed in the following form:

$$
\mathrm{Nu}(\operatorname{air})=0.111 *(\operatorname{ReA} * * 0.65) *(\operatorname{Pr} * * 0.333)
$$

These heat transfer correlations depend on the specific method of construction (welded, pressed, etc.) and the type of fin (straight, wavy) and will vary considerably among manufactures. The above correlations were compared to the heat exchanger performance published by two heat exchanger manufactures and the results of this comparison were used to determine a correlation for the model:

$$
N u(\operatorname{air})=0.180 *(\operatorname{Re} * * 0.60) *(P r * * 0.333)
$$


A-1.4 Comparison to Manufacturers Data

The two heat exchangers examined and their respective manufacturers are listed below. Figure A-1 shows the results of analyzing heat exchanger " $A$ ". and figure $A-2$ shows the results of analyzing heat exchanger " $B$ ". As these figures show there is a large dependance on the correlation used and variation from manufacturer to manufacturer. In some cases it appears that the manufacturing data may be slightly conservative.

Air - Water Heat Exchanger 'A'

Bohn Aluminum and Brass Company

1 row

frontal height $=12.5$ in.

frontal width $=14.0 \mathrm{in}$.

exchanger depth $=1.0$ in.

0.5 inch $0 . D$. coppper tubes

0.006 inch aluminum fins

10 fins per inch

$3 \mathrm{ft} / \mathrm{sec}$ water velocity

180 F entering water

70 F entering air

Air - Water Heat Exchanger ' $B$ '

Environmental Elements Corporation, Titus Products (22)

Titus size $9 / 10$

1 row

frontal height $=12.5$ in.

frontal width $=14.0$ in.

exchanger depth $=1.0$ in.

0.5 inch $0 . D$. copper tubes

0.006 inch aluminum fins

8.0 gpm water flow

$180 \mathrm{~F}$ entering water

70 F entering air 


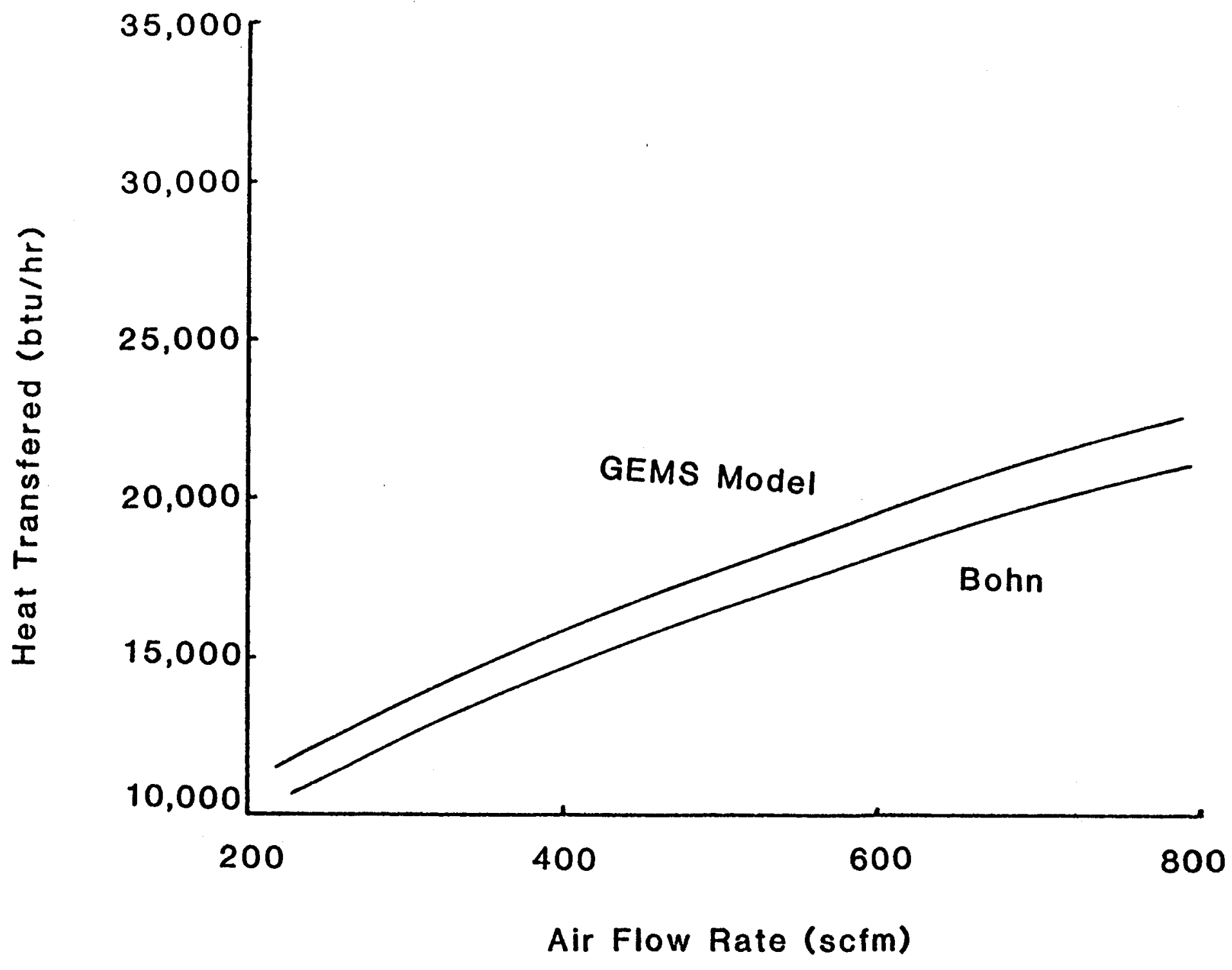

FIGURE A-1: COMPARISON OF GEMS MODEL WITH BOHN DATA 


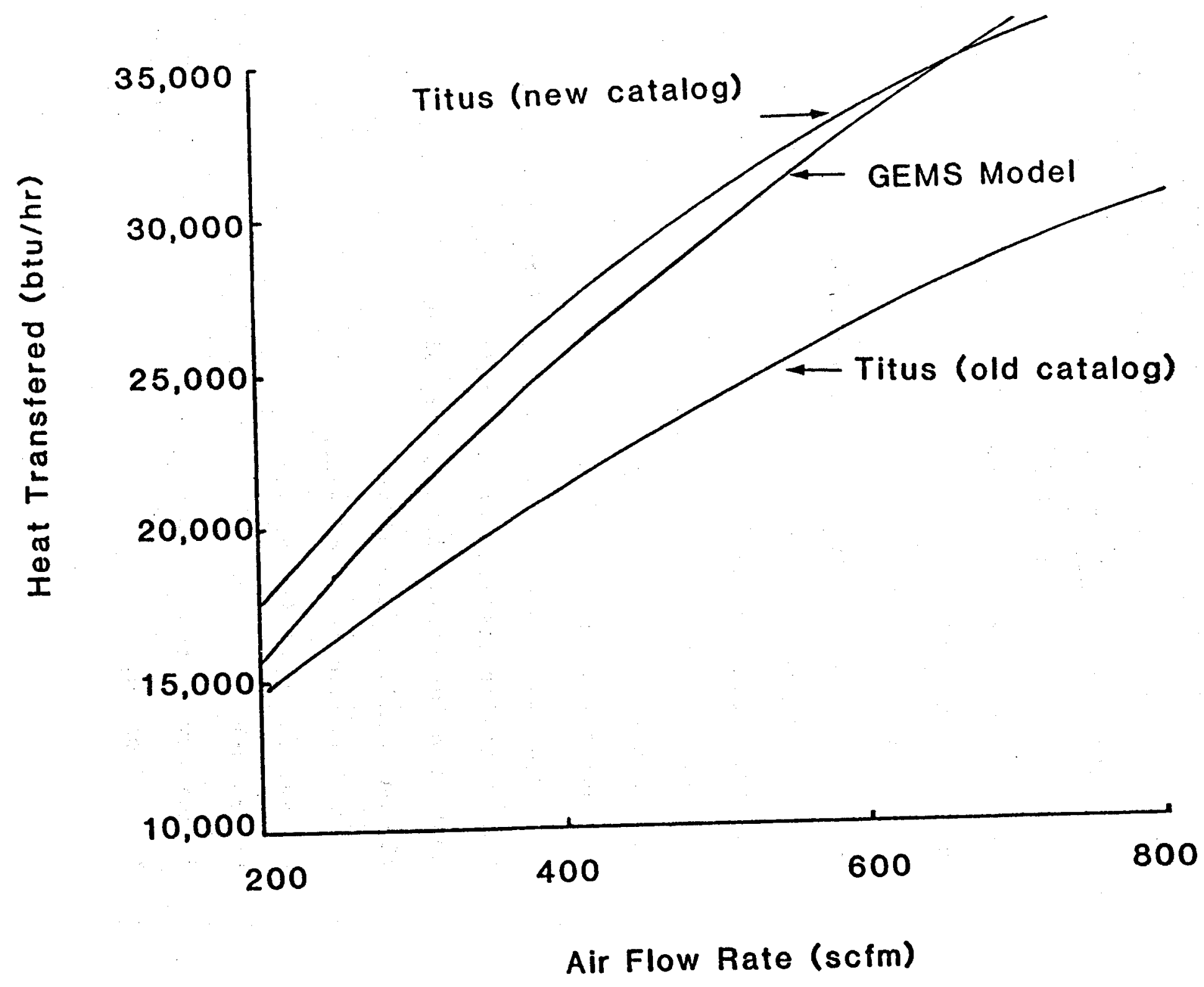

FIGURE A-2: COMPARISON OF GEMS MODEL WITH TITUS DATA 
A-1.5 Nomenclature for AWHX Equations

\begin{tabular}{|c|c|c|}
\hline$A(f i n)$ & $=$ & heat transfer surface area of fin \\
\hline A (tube) & $=$ & heat transfer surface area of tube (air side) \\
\hline$C$ (hot) & $=$ & capacity rate of hot fluid (mass flow $x$ heat capacity) \\
\hline$C(\operatorname{col} d)$ & $=$ & capacity rate of cold fluid \\
\hline$C(\min )$ & $=$ & minimum of $C$ (hot) and $C(\operatorname{col} d)$ \\
\hline$C(\max )$ & $=$ & maximum of $C$ (hot) and $C$ (cold) \\
\hline $\operatorname{Cp}(\operatorname{air})$ & $=$ & heat capacity of air \\
\hline Cp (water) & $=$ & heat capacity of water \\
\hline$D(e f f)$ & $=$ & $4.0 \times$ (hydraulic radius) $=4.0 \times$ hrad \\
\hline$D($ tube) & $=$ & inside diameter of tube \\
\hline $\mathrm{EA}$ & $=$ & exchanger effectiveness \\
\hline $\mathrm{FF}$ & $=$ & fouling factor \\
\hline $\mathrm{FH}$ & $=$ & fin height \\
\hline hrad & $=$ & hydraulic radius \\
\hline$h($ air) & $\begin{array}{l}= \\
=\end{array}$ & $\begin{array}{l}\text { exchanger depth } \mathrm{x} \text { min. air flow area / total H.T. area } \\
\text { heat transfer coefficient (air side) }\end{array}$ \\
\hline h (water) & $=$ & heat transfer coefficient (water side) \\
\hline$k(a i r)$ & $=$ & thermal conductivity of air \\
\hline $\mathrm{k}$ (water) & $=$ & thermal conductivity of water \\
\hline$k(f i n)$ & $=$ & thermal conductivity of fin \\
\hline 1 & $=$ & fin height \\
\hline$N(E)$ & $=$ & efficiency of fin surface \\
\hline$N(0)$ & $=$ & fin efficiency \\
\hline
\end{tabular}




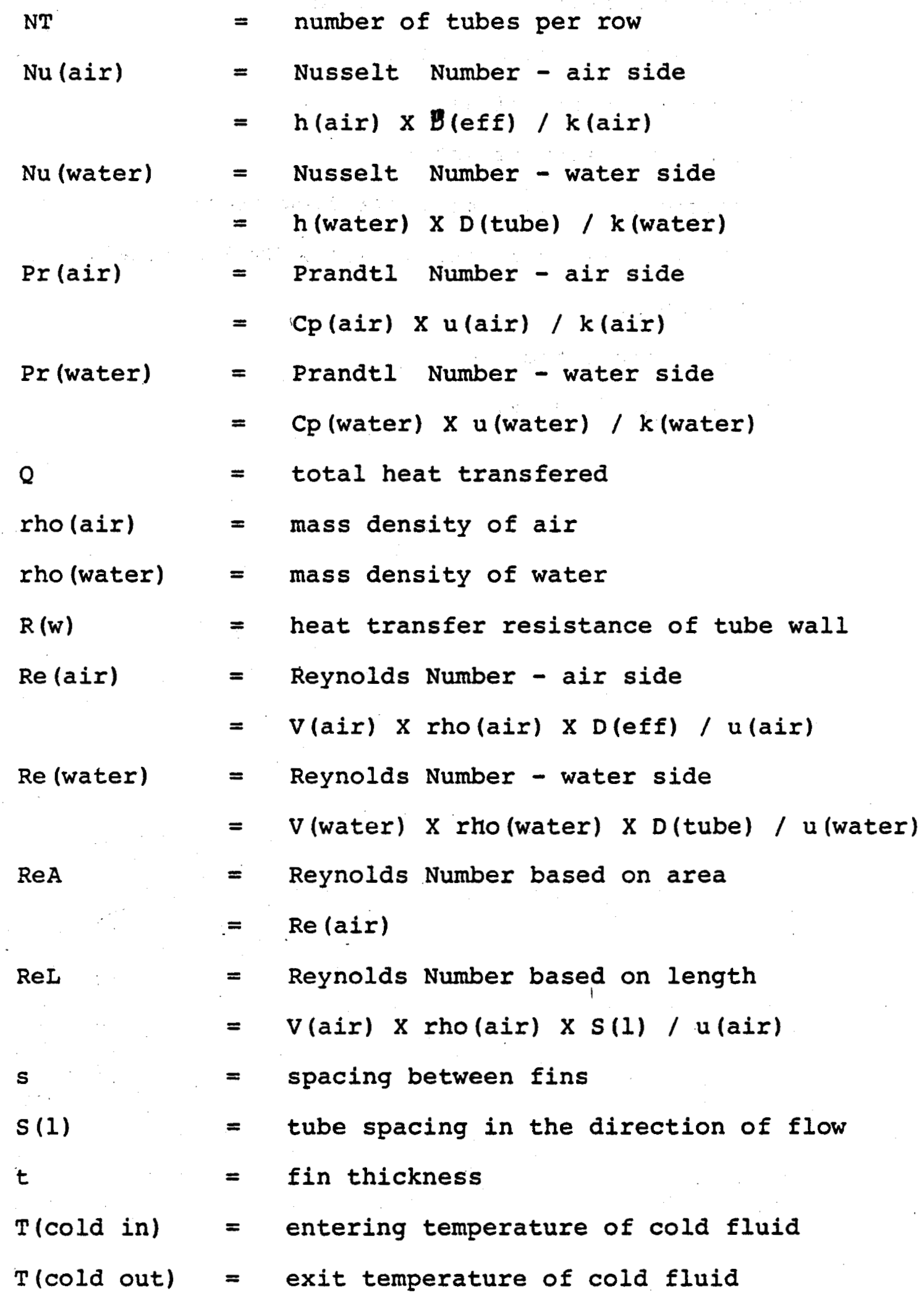


$\mathrm{T}$ (hot in) = entering temperature of hot fluid

$T$ (hot out) = exit temperature of hot fluid

u(air) = absolute viscosity of air

$\mathrm{u}$ (water) $\quad=$ absolute viscosity of water

$\mathrm{V}(\mathrm{air})=$ volumetric air flow / min. air flow area

$V$ (water) = mass flow of water / (tho(water) $\times$ NT X A (tube))

$x(f i n)=$ fin thickness

ZA

= capacity rate ratio

$=c(\min ) / C(\max )$ 


\section{A-2, Plate Heat Exchanger}

A computer program to model the operation of a plate heat exchanger was developed using the NTU approach as presented by Rohsenow and Hartnett (23). The flow passages between the plates in these heat exchangers are designed to be extremely tortuous. Thus they create greater turbulence and increase the heat transfer rate above the values found for flow between flat parallel plates. Information relating to the heat transfer rates in these heat exchangers is strongly dependant on the specific heat exchanger used and the degree of turbulence achieved within that exchanger. The following sections describe the equations and calculational procedures used within the plate heat exchanger model.

\section{A-2.1 Primary Equations}

The equations used for this model were obtained from the A.P.V. Company, Inc., Tonawanda, New York (24). This company manufactures and selis plate heat exchangers. They reported heat transfer coefficients for their heat exchangers in terms of the following equation (see section A-2.4 for nomenclature):

$$
N u=0.28 *(\operatorname{Re} * \star 0.65) *(\operatorname{Pr} * * 0.4)
$$


They also reported equations governing the pressure drop in their exchangers, which has also been included in the model:

$$
\begin{aligned}
& \text { Press. Drop }=2 * f *(G * * 2) * L /(g * \text { rho } * D(e)) \\
& \text { where } f=2.5 *\{(G * D(e) / u) * *-0.3\}
\end{aligned}
$$

These equations were assumed to be accurate or slightly conservative and should be confirmed by comparison with operating data for several heat exchangers.

\section{A-2.2 Calculational Procedure for Plate Heat Exchanger}

The following calculational procedure determines the outlet temperature given the exchanger construction details and the inlet conditions. This procedure is based on the work of Kays and Iondon (18) as presented by Rohsenow and Hartnett (23) .

1. Input construction details

2. Input temperature and flow of inlet air

3. Input temperature and flow of inlet water

4. Guess outlet stream temperatures

- outlet temperature 1 = inlet temperature 1

- outlet temperature 2 = inlet temperature 2

5. Calculateaverage stream temperatures

$-T($ avg $)=(T($ inlet $)+T$ (outlet) $) / 2.0$ 
6. Calculate fluid properties as a function of their respective average stream temperatures

- density

- thermal conductivity

- heat capacity

- viscosity

7. Calculate flow area

8. Calculate heat transfer area

9. Calculate fluid velocities

10. Calculate dimensionless properties

- Reynolds Number

- Prandt l Number

- Nusselt Number

- Capacity Rate Ratio

11. Calculate heat transfer coefficients

12. Calculate average overall heat transfer coefficient

13. Calculate NTU based on minimum capacity rate

14. Calculate exchanger effectiveness using the correlation for counter-flow heat exchangers, Rohsenhow and Hartnett (23)

15. Calculate total heat transfered

16. Calculate oulet temperatures of both fluids

17. Compare outlet temperatures with those from the previous guess and return to step number 5 if not converged 
A-2.3 Nomenclature for Plate Heat Exchanger

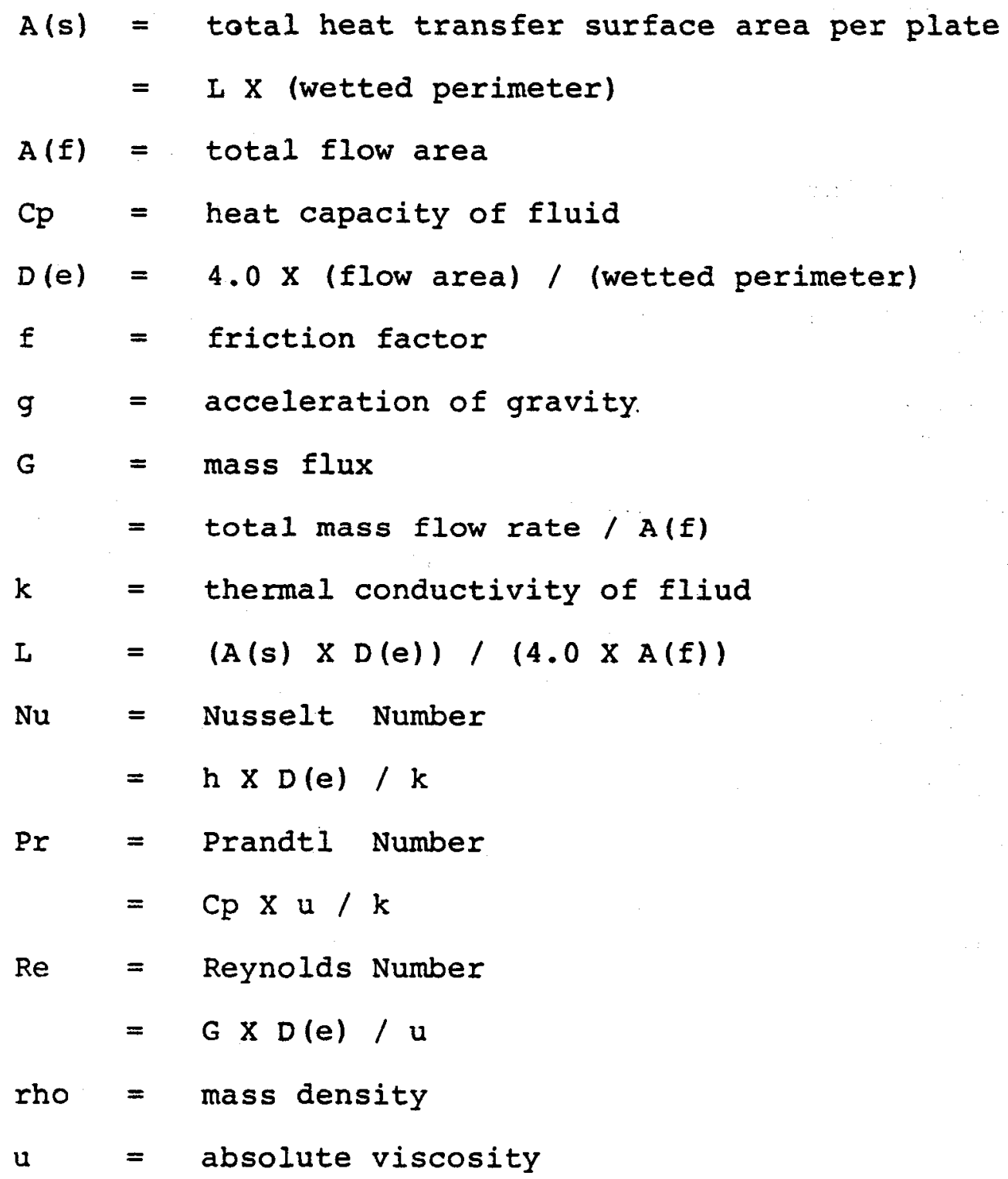


APPENDIX B: Modeling with AWHX

The GEMS model of an air-water heat exchanger (AWHX) is designed to model a single row, single pass heat exchanger. other heat exchanger flow configurations can be modeled by properly cambining the GEMS modules. The following sections describe the procedures required to model four of the basic air-water heat exchanger configurations. Other heat exchangers can be modeled by a simple extension of these examples. Following these four examples are some guidelines for combining heat exchangers in series or in parallel into one GEMS module.

The definitions of various terms used in describing air-water heat exchangers vary between manufacturers. It is best to obtain a good understanding of a the water circuiting in an exchanger before attempting to construct a GEMS model. The following definitions apply.

Passes: The number of times that the water travels from one side of the heat exchanger to the other between entering and leaving the heating coil.

Circuit: Each type of circuit defines a specific path sequence to pass the water through the exchanger. In the following sections three circuit types are described, half, full, and double circuit.

Row: A single column of tubes aligned perpendicular to the direction of the air flow. 
HALF CIRCUIT - SINGLE ROW
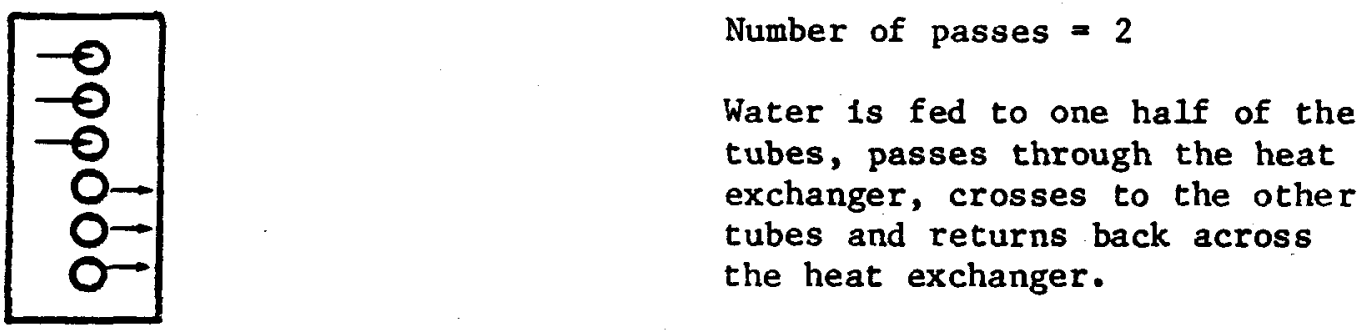

water in

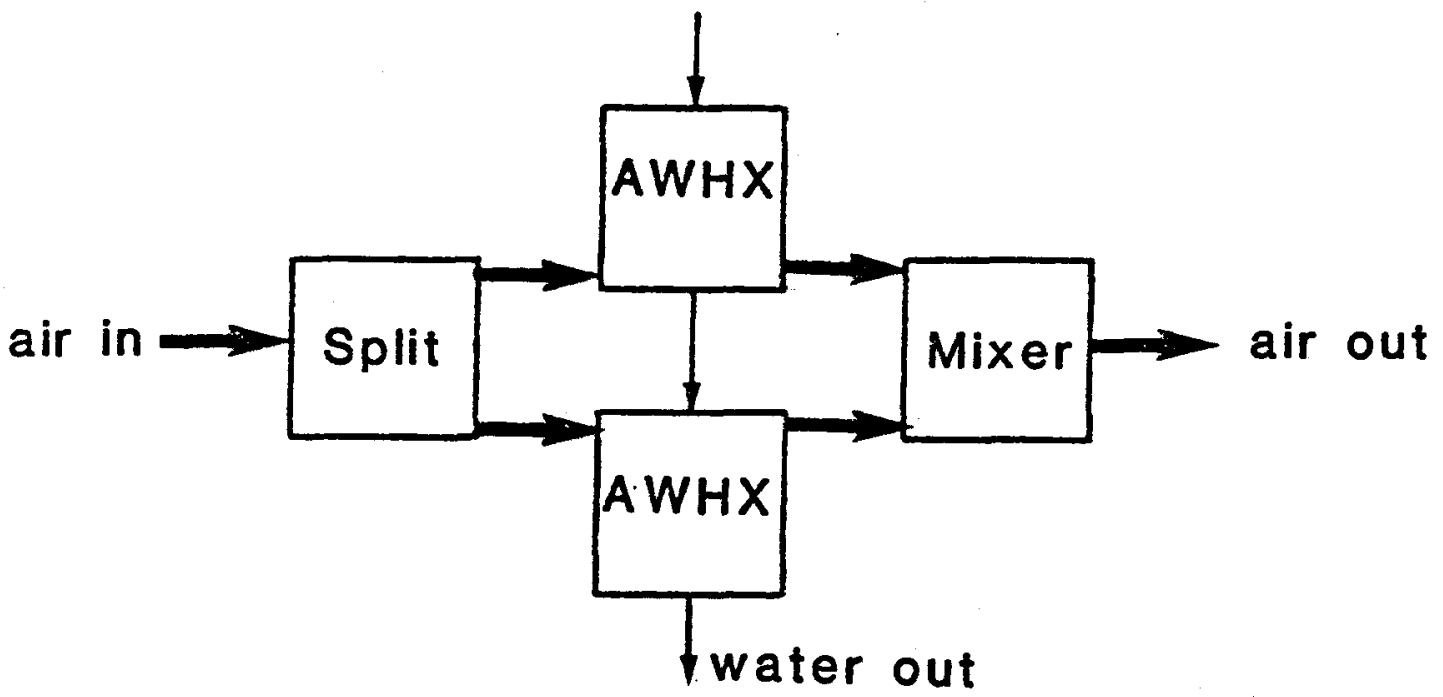

*Each AWHX is represents a heat exchanger that is one half the total finned height of the heat exchanger being modeled. 
FULL CIRCUIT - SINGLE ROW

Side View of Heat Exchanger
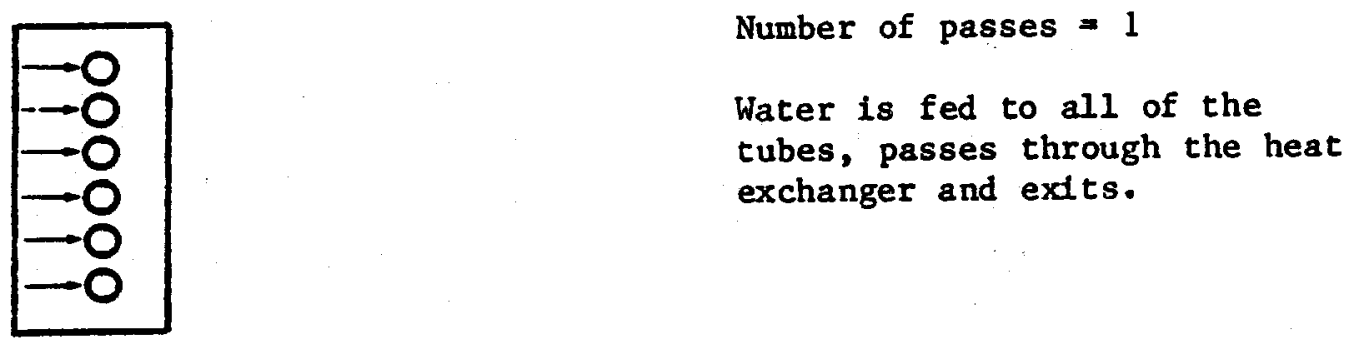

GEMS Model

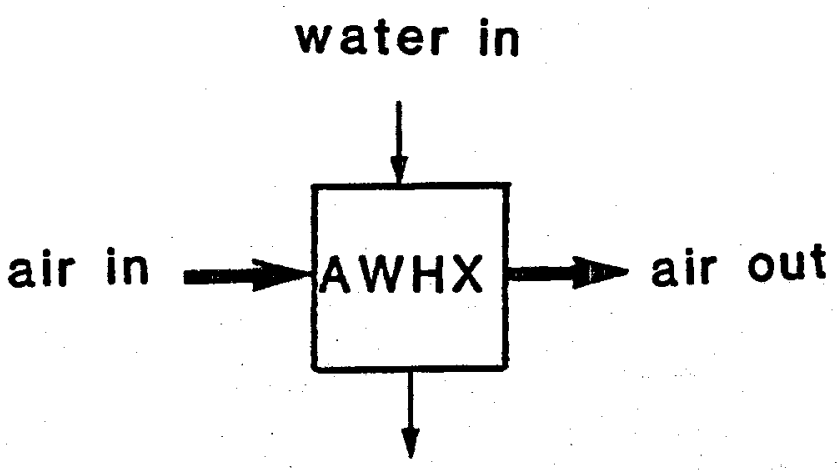

water out 
FULL CIRCUIT - DOUBLE ROW

Side View of Heat Exchanger

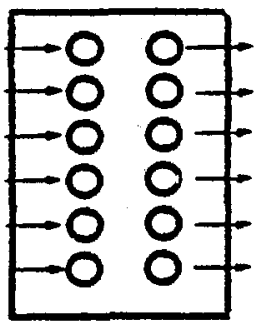

Number of passes $=1$

Water is fed to the first row of tubes, passes through the heat exchanger, crosses over to the second row, and returns back through the heat exchanger.

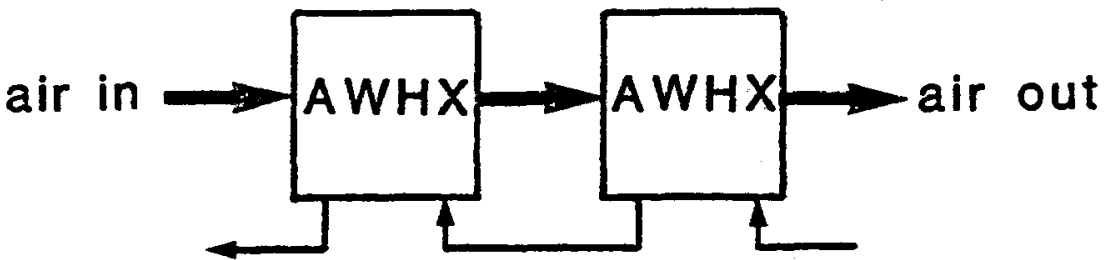

water out

water in

*Each AWHX represents one row of the heat exchanger being modeled. 
DOUBLE CIRCUIT - DOUBLE ROW

Side View of Heat Exchanger

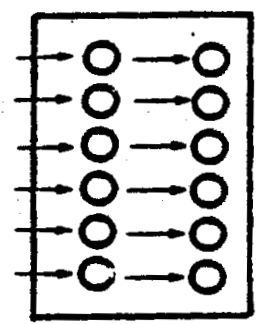

Number of passes $=1$

Water is fed to all of the tubes in the first two rows, passes through the exchanger and exits.

GEMS Mode1

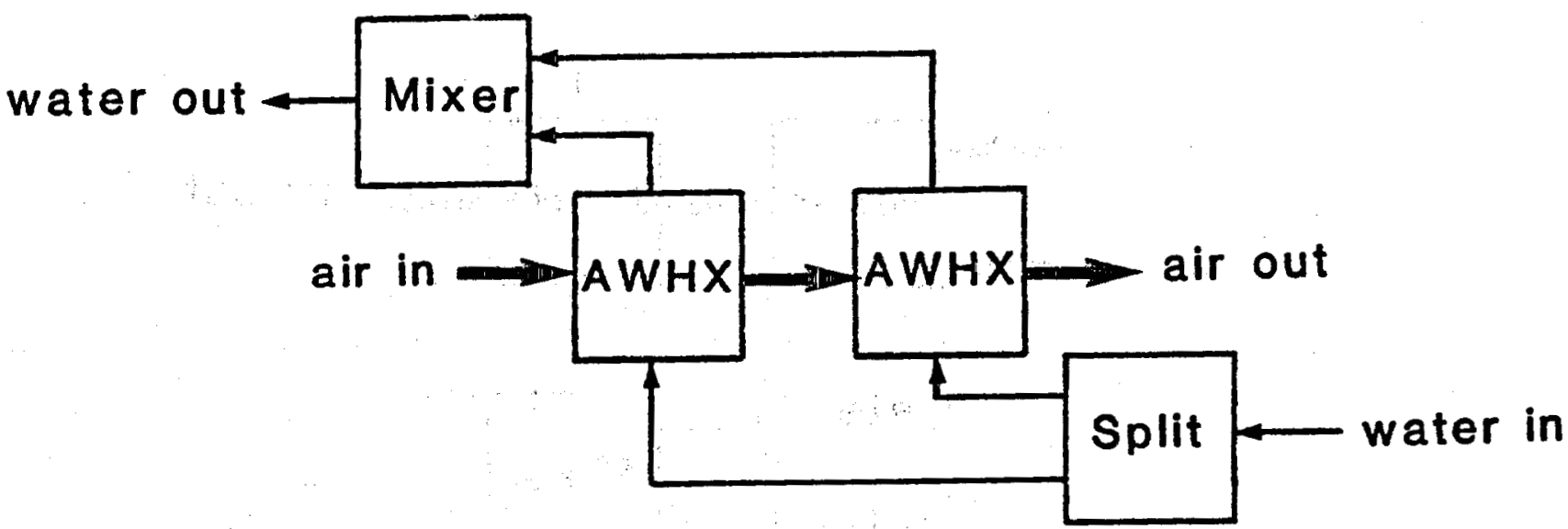

*Each AWHX represents one row of the heat exchanger being modeled. 
HEAT EXCHANGERS IN PARALLEL

\section{Restrictions}

1. Same entering air temperatures.

2. Same entering hot water temperatures.

3. Heat exchangers must be identical except for their frontal helght and number of tubes per row.

4. Air face velocities should be approximately equal.

GEMS Model

1. Add air flow rates

2. Add water flow rates

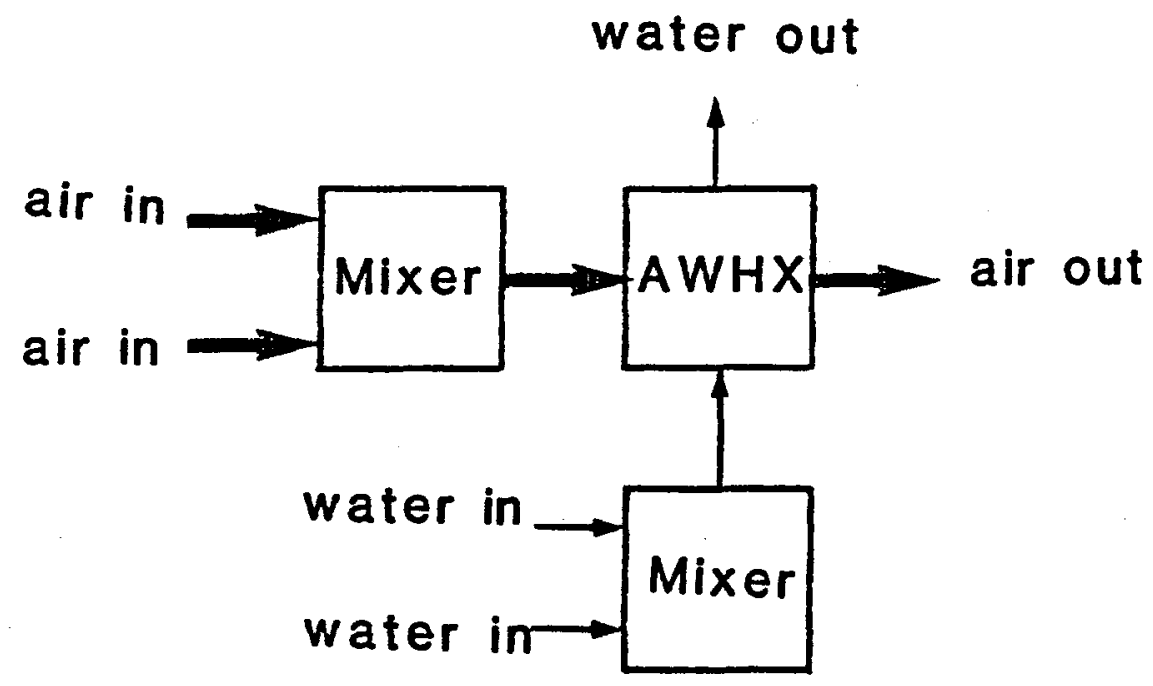

*AWHX is increased in size by adding the frontal heights and modeling as in the previous sections. 


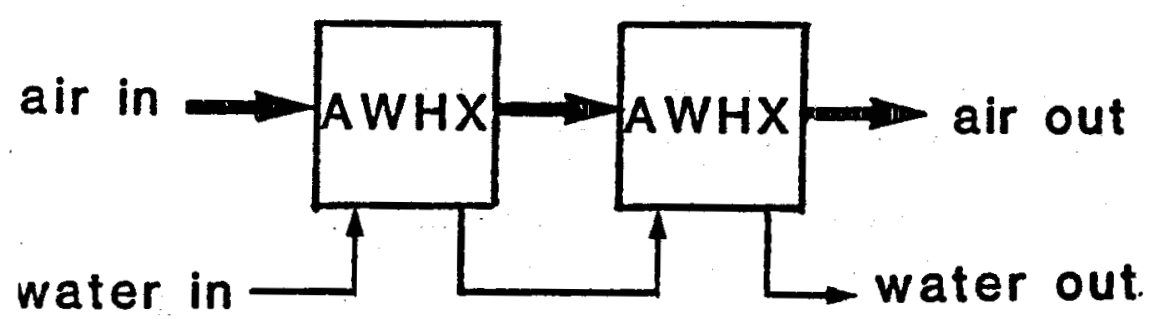

This is identical to full circuit - two row

Example 2:

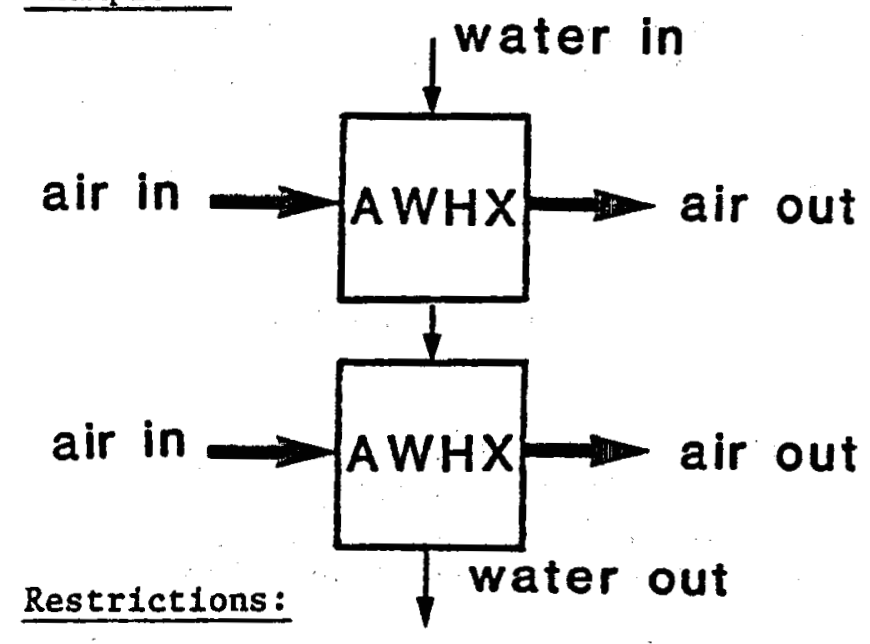

1. Entering alr at same conditions

2. Heat exchangers must be identical except for the frontal length.

3. Air face velocities should be approximately equal.

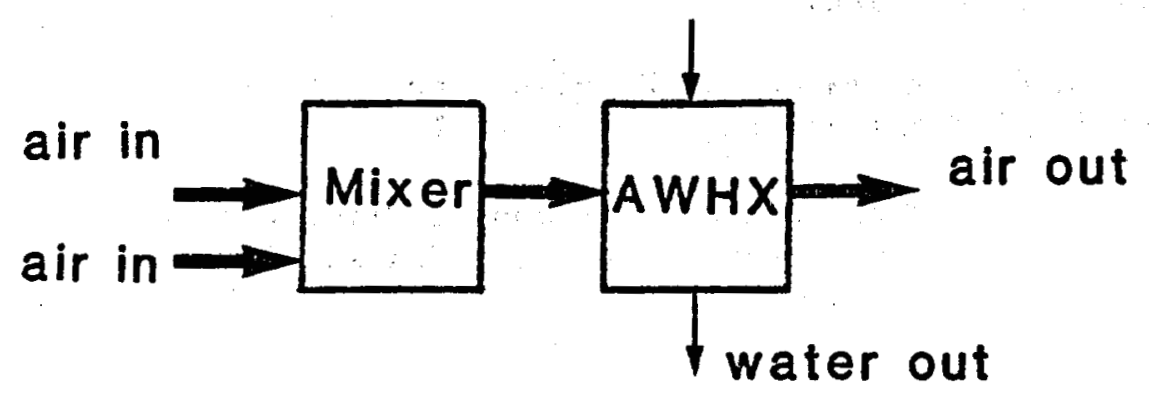




\section{REFERENCES}

1. "Geothermal Resources and Technology in the United States", National Research Council, Study of Nuclear and Alternative Energy Systems, Supporting Paper \#4, 1979.

2. Blerman, S. L., Stover D. F., Nelson P. A., and W. J. Lamont, "Geothermal Energy in the Western United States", Praeger Publishers, New York, 1978.

3. Cheremisinoff, P. N., and A. C. Morresi, "Geothermal Energy Technology Assessment", Technom1c Publishing Co., 1976.

4. Sung, R., Houser, G., Strehler, D., and K. Scheyer, "Sampling and Analysis of Potential Geothermal Sites", EPA Project Summary, EPA-600/S7-81-138, October 1981 .

5. Freeman, T., "TRNSYS, A Transient Simulation Program", Report \#38, University of Wisconsin Solar Energy Laboratory, Madison, Wisconsin, September 1976.

6. Edwards, L. L., and R. Baldus, "GEMS Documentation Describing Data Input, Simulation Options", Idaho Research Foundation, Moscow, Idaho, 1977.

7. Kusuda, T., "A Comparison of Energy Calculation Procedures", ASHRAE Journal, August 1981, pp 21-24.

8. Handbook of Alr Conditioning System Design, Carrier Air Conditioning Company, McGraw Hi11, 1965.

9. Bloomster, C. H., Fassbinder, L. L., and C. L. McDonald, 1977, "Geothermal Energy Potential for District and Process Heating Applications in the U.S. - An Economic Analysis", Geothermal Energy Recent Developments (ed. M.J. Collie), Noyes Data Corporation, 1978.

10. Wiser, E. H. 1975b. "HISARS Hydrological Information Storage and Retrleval System - Reference Manual", North Carolina Ag Experiment Station, Technical Bulletin \#215.

11. Batdorf, J. A., and G. M. Simmons, "Economical Advantages in Using Conventional Energy Supplements in the Design of Geothermal District Heating Systems", Geothermal Resources Counctl Transactions, 7, October, 1983.

12. Rolfson, B., "A Pre-packaged GEMS Simulation for Geothermal Heating", MS Thesis, University of Idaho, August 1984.

13. Simmons, G. M., Al1, S. I., and J. A. Batdorf, "Modeling and Control of Geothernal Heating Systems," ISA Transactions, 20 (1), 1981

14. Simmons, G. M., and J. A. Batdorf, "Application of Computer Simulation to Geothermal Heating Systems", Geothermal Resources Councll Transactions, 4, September 1980. 
15. Baldus, R., and L. L. Edwards, "Evaluation of Power and Steam Generating Al ternatives of Kraft M118", TAPPI, 6(9), Sept. 1978.

16. Gunseor, F., and J. Rushton, "Computer Simulation of a Bleached Kraft Pulp and Paperboard Mi11", TAPPI, 62(3), March 1979.

17. Al1, S. I., "Application of GEMS in Air Conditioning Design", Master of Sclence Thesis, Universicy of Idaho Graduate School, 1979.

18. Kays, W. M. and A. L. London, "Compact Heat Exchangers", The National Press, Palo Alto, Callfornia, 1955

19. Briggs, D. E. and E. H. Young, "Convection Heat Transfer and Pressure Drop of Alr Flowing across Trlangular P1tch Banks of Finned Tubes", Chem. Engr. Prog. Sym. Ser., Vo1. 69, no. 71, pp 1-10, 1963.

20. Rich, D. G., "The Effects of Fin Spacing on the Heat Transfer and Friction Performance of Multi-Row, Smooth Plate Fin-and-Tube Heat Exchangers", ASHRAE Trans., Vo1. 79, pt. 2, pp 137-145, 1973.

21. "Type 5 Water HeatIng Colls", Bohn Aluminum and Brass Corporation, Danville, Illinols.

22. "Titus Products - HVAC Alr Distribution Components and Systems", EP 78, Environmental Elements Corporation

23. Rohsenow, W. M. and J. P. Hartnett, "Handbook of Heat Transfer", McGraw H111 Book Company, New York, 1973.

24. Heat Transfer Handbook, "Design and Application of Paraflow Plate Heat Exchangers", Second Edition, A. P. V. Company, Inc., New York. 